University of Louisville

ThinkIR: The University of Louisville's Institutional Repository

$5-2014$

\title{
Transboundary groundwater and unsustainable practices of water governance in the Guarani Aquifer : the case of the province of Misiones.
}

Paula Carolina Gomez 1974-

University of Louisville

Follow this and additional works at: https://ir.library.louisville.edu/etd

Part of the Geography Commons

\section{Recommended Citation}

Gomez, Paula Carolina 1974-, "Transboundary groundwater and unsustainable practices of water governance in the Guarani Aquifer : the case of the province of Misiones." (2014). Electronic Theses and Dissertations. Paper 513.

https://doi.org/10.18297/etd/513

This Master's Thesis is brought to you for free and open access by ThinkIR: The University of Louisville's Institutional Repository. It has been accepted for inclusion in Electronic Theses and Dissertations by an authorized administrator of ThinkIR: The University of Louisville's Institutional Repository. This title appears here courtesy of the author, who has retained all other copyrights. For more information, please contact thinkir@louisville.edu. 
TRANSBOUNDARY GROUNDWATER AND UNSUSTAINABLE PRACTICES OF WATER GOVERNANCE IN THE GUARANI AQUIFER: THE CASE OF THE PROVINCE OF MISIONES

\author{
By \\ Paula Carolina Gómez
}

\begin{abstract}
A Thesis
Submitted to the Faculty of the

College of Arts and Sciences of the University of Louisville

In Partial Fulfillment of the Requirements

For the Degree of
\end{abstract}

Master of Science

Department of Geography and Geosciences

University of Louisville

Louisville, Kentucky

May 2014 
Copyright 2014 by Paula Carolina Gómez

All Rights Reserved 

TRANSBOUNDARY GROUNDWATER AND UNSUSTAINABLE PRACTICES OF WATER GOVERNANCE IN THE GUARANI AQUIFER: THE CASE OF THE PROVINCE OF MISIONES

\author{
By \\ Paula Carolina Gómez
}

A Thesis Approved on

April 21, 2014

By the following Thesis Committee

Prof. Margath Walker

Prof. Jairus Rossi

Prof. Jonathan Haws 


\section{ACKNOWLEDGEMENTS}

This thesis would have not been possible without the guidance of my committee members, friends, and the support of my two children. I would first like to thank my principal thesis advisor, Prof. Margath Walker, for her immense support, guidance and insightfulness throughout this process. This research project has been significantly influenced by her knowledge and scholarship, which I greatly admire. I also would like to thank Prof. Jonathan Haws for his invaluable guidance, support and insightful comments throughout these years, and Prof. Jairus Rossi for willing to be my second advisor without much notice and for taking the time to provide me with excellent comments to my research. In addition, I would like to thank Prof. Jafar Hadizadeh for his tremendous insight, intuition and input throughout these years, particularly to my research proposal, which has led me to my present research argument. I dedicate this research project to him.

I am most thankful for my sons Mika and Milo Paciorek, who have provided me with an ultimate source of inspiration and strength to complete this project. A special thanks to my fellow graduate students and friends Trey Nunn and Michael Poindexter, for their incredible support and camaraderie. Finally, I would like to thank the participants from Misiones, Argentina, who kindly accepted to take part of this research as interviewees, and to whom I am very grateful. 


\begin{abstract}
TRANSBOUNDARY GROUNDWATER AND UNSUSTAINABLE PRACTICES OF WATER GOVERNANCE IN THE GUARANI AQUIFER: THE CASE OF THE PROVINCE OF MISIONES

Paula Carolina Gomez

April 21, 2014

Recent changes in the governance of the Guarani Aquifer System - a transboundary groundwater resource in South America - reveal contradictory practices of water governance embedded in the individual politics and ideologies of sovereign states overlying the aquifer. Emerging practices of water marketization through the commodification of bottled groundwater at the provincial level in Misiones, Argentina, contest the current scale of transboundary groundwater governance, delimited by The Guarani Aquifer Agreement and its main principles of cooperation, equitable and reasonable utilization and the obligation not to harm - under the imperatives of the United Nations International Law Commission (UNILC) Law of Transboundary Aquifers. Embedded in discourses of neoliberal ideology, these practices naturalize an economic scale enclosed in multi-scalar networks of capital accumulation and profit-making, largely resulting in the unsustainable utilization of natural resources.
\end{abstract}


Furthermore, Misiones' recent water reform and transfer of use rights to the state-owned water bottling corporation Aguas Misioneras Sociedad del Estado (AMSE), reveal a centralization of decision-making processes at the provincial level which questions Misiones' level of adherence to this treaty and thus, the sustainable development of the GAS. Employing discourse analysis, I examine Misiones' discourses of water governance through archival documents, news media and interviews, to elucidate on their role in materializing practices of water commodification in Misiones. In turn, I argue that Misiones' practices of water marketization, legitimized through newly developed water policy, are not conducive to the sustainable development of the Guarani Aquifer System. 


\section{TABLE OF CONTENTS}

PAGE

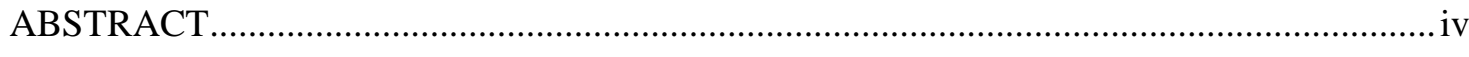

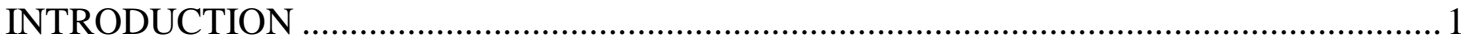

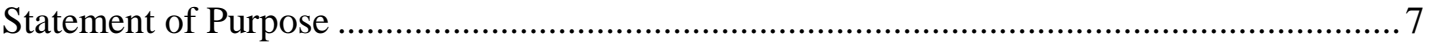

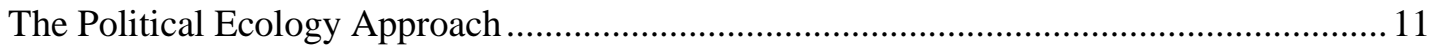

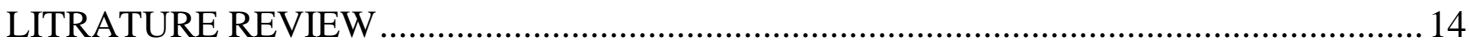

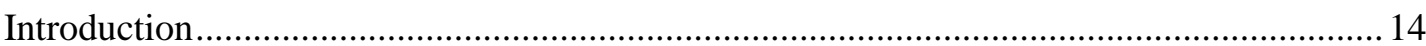

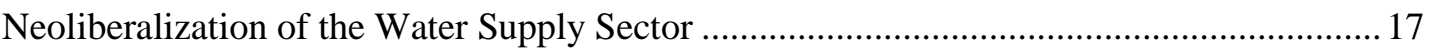

Discourses of Sustainable Development and International Water Law Principles ................. 31

Power Asymmetries, Cooperation and the Politics of Scale ................................................... 46

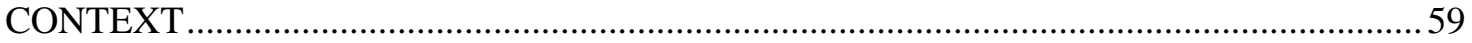

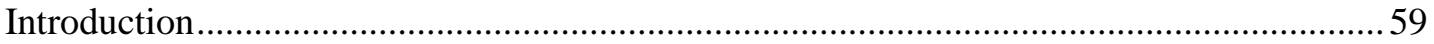

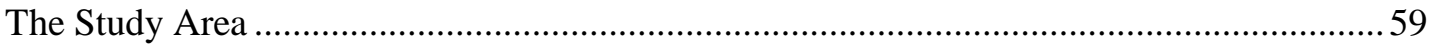

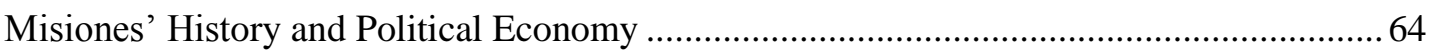

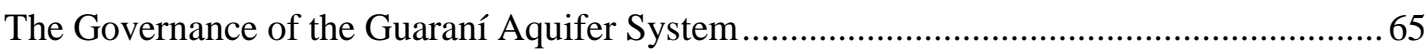

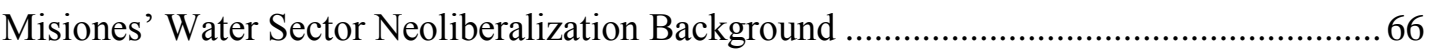

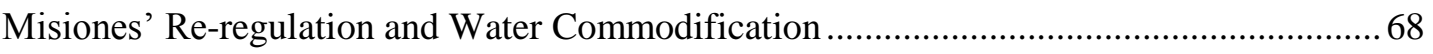

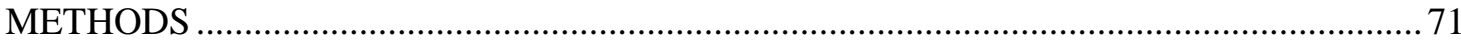

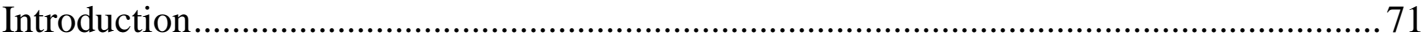

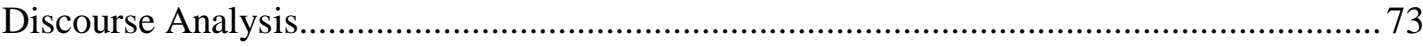

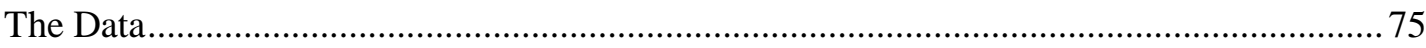

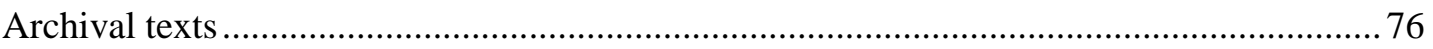

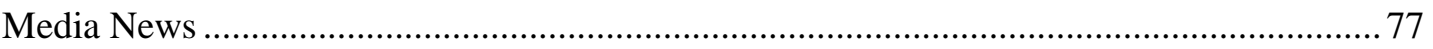

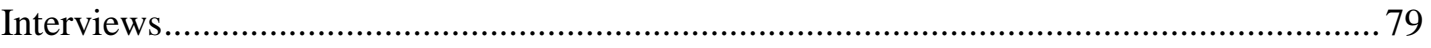

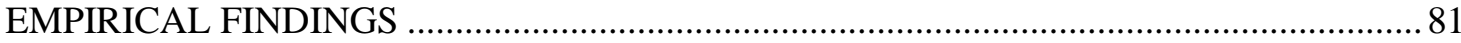

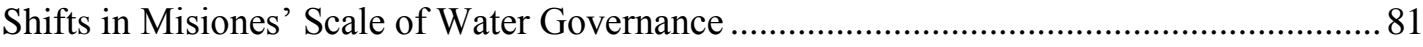

AMSE's Dual Market-oriented and Keynesian-Welfarist Discourse .................................... 84 


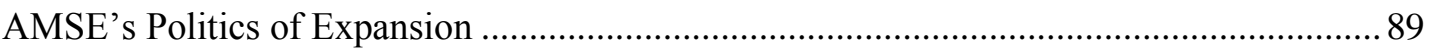

“Botellitas de Identidad" (Little Water Bottles of Identity).....................................................94

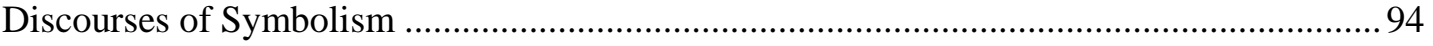

“Otros Lo Explotan Más Que Nosotros” (Others Exploit It More Than Us)......................... 96

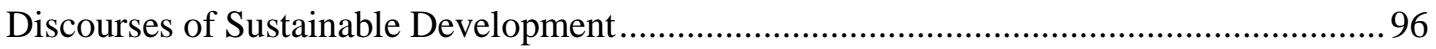

AMSE's Authoritative Knowledge in Misiones' Water Governance ................................... 100

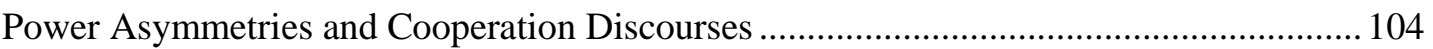

Misiones' Current Politics of Water Governance ......................................................................... 108

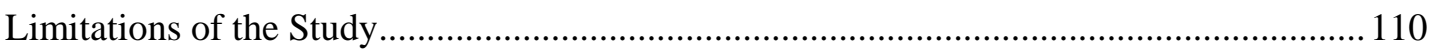

CONCLUSION

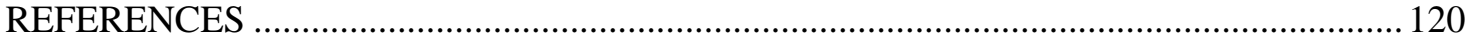

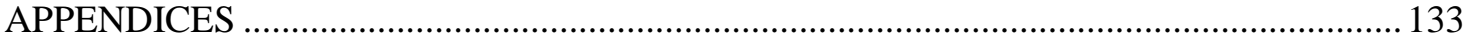

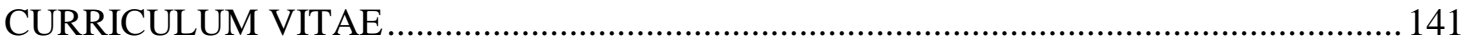




\section{LIST OF TABLES}

TABLE

PAGE

1. Legal Instruments Intervening in the Water Governance of Misiones ..................................... 78 


\section{LIST OF FIGURES}

FIGURE

PAGE

1. The Spatial Evolution of Water Management..........................................................................58

2. The Guarani Aquifer System and the Province of Misiones...................................................... 62

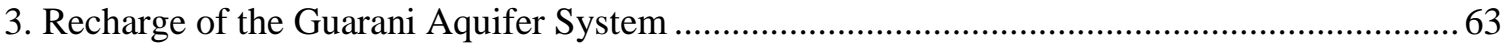

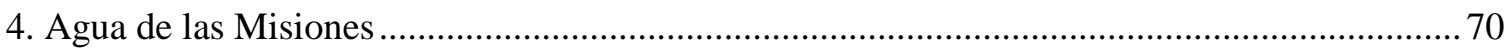

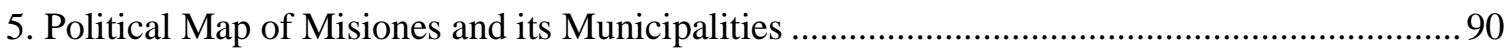

6. Enlarged Section map of Jesuit Settlements in Misiones..........................................................92 


\section{CHAPTER I}

\section{INTRODUCTION}

This analysis investigates how newly emerging practices of water commodification and re-regulation in the province of Misiones, Argentina, get integrated into social norms through shifts in state ideology, and the production of new "authoritative knowledge" (Bakker 1999; Goldman 2001), queried through Misiones' discourses of water governance. In this respect, this study centers its methodological analysis within the "production of knowledge" in Misiones' water governance, intrinsically interwoven in socio-cultural norms through distinctive discursive instances (such as acceptance, rejection and/or normalization), and simultaneous shifts in state ideology and practices (Feitelson and Fischhendler 2009; Blatter and Ingram 2001). Particularly relevant to this analysis are the emerging discourses at the state level, which seek to naturalize new regulatory reforms and delineate how water should be perceived, allocated, governed and controlled. Furthermore, this analysis elucidates how these processes simultaneously enable and deter particular scales of water governance, which in turn, may pose significant to the sustainable governance of the GAS.

The Guarani Aquifer System (GAS) - a transboundary groundwater resource in South America - has been subject to changes in its form of governance during the past decade. These changes have involved a neoliberal (politico-economic projects that favor free-market regimes as a solution to resolve and/or prevent environmental crises) transnational intervention by the World Bank and lending institutions such as the Global Environment Facility (GEF) and the Organization of American States (OAS) to promote the sustainable governance of the GAS. This 
intervention resulted in the Proyecto para la Proteccion Ambiental y Desarrollo Sostenible del Sistema Acuífero Guarani (The Guarani Aquifer Environmental Protection and Sustainable Development Project) valued in \$26.7 million, which was implemented from 2003 to 2009 and carried a privatization schedule for the GAS (World Bank 2006; World Bank 2009; Perreault 2008; Síndico 2011; Pochat 2011; OAS 2005).

As a means to provide a protective framework for the GAS without transnational neoliberal intervention, the four sovereign countries to the GAS (Brazil, Argentina, Paraguay and Uruguay) signed the Guarani Aquifer Agreement (GAA) in 2010. This was the first agreement resulting from the United Nations International Law Commission (UNILC) 19 draft articles on the Law of Transboundary Aquifers, crafted in 2008. The GAA reaffirmed the four countries' sovereignty over the GAS and prescribed specific guidelines to the sovereign parties, for its sustainable governance. Consequently, this shift involved a change in the scale (the level at which decision-making processes occur) of governance (Marston 2000), from a multi-scalar neoliberal transnationally-led mode of governance to an internationally-led (and regional) legal mode of governance (Perrault 2008; World Bank 2009; Stephan 2011; Pochat 2011).

In 2010, the province of Misiones, Argentina (a sovereign province to the GAS), reaffirmed its public domain rights over its territorial water resources through re-regulation while the state-owned water corporation Aguas Misioneras Sociedad del Estado (AMSE) was created to commodify bottled water from any territorial freshwater from the province of Misiones (including GAS groundwater). This process involved the insertion of market-based principles in Misiones' water sector, which marketized its water governance processes. Misiones' recent water policy reform and AMSE's politics of expansion to global markets through the bottled water business pose questions as to whether this treaty is functional and if sovereign states to the GAS are adhering to the principles established in this treaty. In doing so, this analysis focuses on the case 
of Misiones' water marketization, as a neoliberal project that follows the imperatives of a capitalist logic, which requires the perpetual dispossession of natural resources via property relations and the enclosure of the commons. I argue that these processes in turn, are not conducive to sustainable processes of water governance, nor do they follow the sustainable development framework embedded in the GAA. Therefore, this study also queries Misiones' adherence to this treaty, measured through its level of cooperation with other sovereign states.

Over the last few decades, groundwater has been utilized worldwide as a readily available solution to unsafe and/or dwindling surface freshwater availability. It is well acknowledged that global population growth, industrialization, agricultural demands and climate change have increased the overreliance on groundwater resources worldwide (Mall et al. 2006; Eckstein 2009; Gleick 1998), particularly in drought-prone regions such as the Middle East, India and Africa, leading to the overexploitation of these resources (Eckstein 2009; Mehta 2003; Shiva 2002; Goldman 2007). Of growing interest, on the other hand, has been the role of human agency in producing similar conditions through unsustainable practices of governance (Ioris 2010; Hestermeyer et al. 2012) which often lead to the degradation of these resources (Whiteford and Whiteford 2005; UNICEF and WHO 2012).

In contemporary capitalistic societies, global neoclassical economic projects intervening in the water sector have elicited a particular shift in the conceptualization of water (freshwater), from a human right to economic good. This has further enabled water resources to be treated as commodities, which in turn, are driven by pricing signals for its most efficient and economically profitable allocation (Baker 2007). In this sense, both real and produced (socially-constructed) freshwater scarcity has been forwarded through neoliberal agendas to achieve maximum profits in the water sector and in the wider scale of water governance. Whether freshwater is abundant or scarce in a relative context, global discourses about "absolute" water scarcity, forwarded through 
international water summits and conferences such as the Water and Environment meeting held in Kyoto in 2003 to discuss the water crisis (Bakker 2007), have enabled market-based interventions in the water sector (Swyngedouw 2005; Shiva 2002).

As freshwater resources increasingly become introduced to markets systems, aquifers around the world are at the center of social and political struggles, as they become targets of different neoliberal projects through which the private sector progressively increases their dispossession via the enclosure of the commons. This has resulted, in many cases, to the citizens' full deprivation from the access to common property resources (Shiva 2002; Goldman 2007; Mansfield 2007; Roberts 2008). This tension has been particularly evident in drought-prone areas such as in the Middle East and India (Shiva 2002; Mehta 2003; Zeitoun 2008) where freshwater resources have become a source of economic and political power. Similarly, another source of tension have emerged in water-abundant areas such as Asia (Goldman 2001), Africa (Goldman 2007) and South America (Pochat 2011), where water-abundant bodies become targets of neoliberal projects mobilized by transnational agencies, non-governmental (NGOs) and think tanks such as the World Bank (WB), the International Monetary Fund (IMF) and the Global Environment Facility (GEF), among others (Foster et al. 2004; Goldman 2007; Ioris 2010; Hestermeyer et al. 2012). As a result, and given that groundwater represents $97 \%$ of the unfrozen freshwater found worldwide (Dellapenna 2011), aquifers have been at the center of many global disputes, the so-called silent "water wars" (Shiva 2002).

Because groundwater often crosses the political boundaries of "two or more political jurisdictions" (Campana 2005, 646), their governance is complex in many dimensions. On the one hand, exogenous political jurisdictions overlying aquifers do not necessarily match the physical structures in which the specific aquifer or aquifer system is contained (such as its catchment structure or basin). On the other hand, the heterogeneous socio-economic landscape of 
overlying sovereign states and their individual politics, often pose difficulties for the joint cooperation among transboundary states (Feitelson and Fischhendler 2009; Kebede, Ketema, and Tesema 2010).

As a means of finding a protection framework for the sustainable governance of transboundary groundwater bodies, especially in conflict-prone areas, international water law has evolved in the form of 19 draft articles crafted by the United Nations International Law Commission (UNILC) on the Law of Transboundary Aquifers (UN 2013d). These articles, if adopted in the form of a treaty, provide states with a legal framework for the joint cooperation and governance of transboundary aquifers. Therefore, states adopting the UNILC Law of Transboundary Aquifers recognize this legal scale of governance and its main principles of cooperation, equitable and reasonable utilization and the obligation not to cause harm to other states involved. In addition, this framework is embedded in a Brundtland definition on sustainable development (Dellapenna 2011; Síndico; 2011Hestermeyer et al. 2012).

Similarly, as a treaty resulting from the UNILC on the Law of Transboundary Aquifers, the GAA provides a regulatory framework for the joint governance of the GAS among the sovereign states (Síndico 2011; Hestermeyer et al. 2012). Furthermore, the main principles of cooperation, equitable and reasonable utilization, and the obligation not to cause harm to other states involved (Linton and Brooks 2011; Hestermeyer et al. 2012), delineate the minimum grounds for the sustainable utilization of the GAS. These articles are based on the central principle of cooperation which refers to the joint planning of activities and active data exchange among the sovereign states (Stephan 2009; Síndico 2011).

However, recent water policy reform and emerging practices of water marketization at the state level in Misiones reveal a change in Misiones' mode of water governance toward market-oriented practices and centralized decision-making process. Consequently, Misiones' 
emerging practices of water governance show divergent from the current legal scale at which the governance of the Guarani Aquifer System has been set, through the Guaraní Aquifer Agreement treaty. 


\section{Statement of Purpose}

Firstly, I build this argument through the literature on neoliberalization; and more specifically through a literature on the "neoliberalization of nature" in environmental governance (Mansfield 2007; Perreault 2008; Bakker 2010). Through this theoretical framework, I argue that emerging practices of water marketization at the provincial (sub-national unit similar to a state) level in Misiones are not sustainable because they are embedded in a profit-making capitalist logic which seeks perpetual forms of capital accumulation through the dispossession of natural resources (Harvey 2003; Glassman 2006; Swyngedouw 2005; Mansfield 2007) and the simultaneous enclosure of the commons (Heynen and Robbins 2005, Swyngedouw 2005, Shiva 2002). In this regard, marketization can be understood as a strategy of "accumulation by dispossession" (Roberts 2008, 540) which redefines the relationships between society and nature (socio-nature) through a set of property relations (ownership rights) (Mansfield 2007). The idea that society and nature are dialectically related (mutually interwoven and affecting their relationship through social processes), has been at the center of critical geography analyses on Marxist tradition (Roberts 2008). Mansfield (2007) for example, analyzes how property and enclosure intervene in the remaking of socio-nature relationships transforming "people's relationships to themselves, others, and nature through ownership and market discipline" (Mansfield 2007, 403).

I draw from this literature because the case of Misiones is inherently embedded in a process of water neoliberalization through the re-regulation, marketization and commodification of water, which redefines who is considered a valid user, exchanger and governor of water. Through these processes, neoliberalism entitles certain parties to dispossess others of their human rights by way of treating water as a marketized commodity. Discourses of scarcity and economic goods are crucial mechanisms by which this shift occurs. This particular case illustrates 
neoliberalism's complexities and contradictions as the state becomes a market itself to achieve the water's socionatural transition from human right to economic good and to displace transnational corporations by way of forwarding the idea that the state can also manage resources efficiently (therefore rejecting the public vs. private binary). Furthermore, this case illustrates the role of discursive politics in enabling a shift in the scale of water governance through narratives of "public domain" and water policy reform (J. Rossi, personal communication, February 2, 2014).

This insertion of market-oriented processes in the governance of natural resources involves a transformation of socio-nature relationships, through a redefinition of their position and order in relation to the type of transformation being encompassed. Some common forms of neoliberal processes (neoliberalization) involve commodification, privatization, commercialization, marketization (or a combination among these), each devising distinctive transformations through specific scripts of property relations (rights) which in turn, redefine citizens as specific "kinds of subjects" (Mansfield 2007, 395; Bakker 2010; Roberts 2008). In addition, these multi-faceted forms of capital reproduction are geographically expansive, as capitalistic processes are known to perpetually seek new forms of capital accumulation through the dispossession of natural resources, resulting in the enclosure of the commons via citizens' loss of rights.

This expansion takes place along two opposite axes; on one side, it occurs through the endless abstraction of natural resources from the commons, which is directly and indirectly detrimental to local livelihoods (through loss and/or degraded land and resources) and the environment (i.e. soil changes, pollution, climate change) (Shiva 2002; Mehta 2003; Perreault 2008; Budds 2004; Prudham 2004). On the other side, this expansion takes place through incessant increases in the production of commodities which not only may result in the 
degradation of natural resources (i.e. through extractive processes and/or pollution deriving from industrialization) but in social labor inequalities and marginalizing processes (such as geographies spatially arranged as production-consumption sites) (Harvey 2003; Swyngedouw 2005; Glassman 2006, 608; Roberts 2008).

Secondly, I build this argument through a literature of discourse on widely accepted notions and critiques on the concepts of sustainable development and the main principles of international water law within transboundary groundwater analysis to provide the basis for the definitions of sustainable development and the main principles of the GAA. Because both sustainable development and the main principles of "equitable and reasonable utilization" and the "obligation to not harm other states involved" are broadly defined, I build on a case through a critical analysis on the minimum grounds these definitions operate (UN 2013d). For example, the principle of equitable and reasonable utilization is implicitly relational and based on the main principle of "cooperation," which explicitly indicates that states should cooperate on a regular basis and exchange reliable updated information to assess equitable and reasonable utilization. This literature mainly addresses the level of ambiguity of these definitions, which allows for subjective interpretation at the local level (socially-constructed) (Linton and Brooks 2011; Dellapenna 2011; Eckstein and Eckstein 2005).

Thirdly, I build my argument through the politics of scale (Marston 2000; Brenner 2001; Swyngedouw 1997) literature applied to water governance (Perreault 2008; Norman and Bakker 2009; Budds and Hinojosa 2012; Norman, Bakker and Cook 2012) and the analytical approach of hydro-hegemony (Zeitoun and Warner 2006) within the International Relations (IR) literature to analyze narratives of power asymmetries and issues of cooperation emerging in Misiones' discourse of water governance. The hydro-hegemony framework provides a basic analytic point for "fixed" and "given" power dynamics at play in the analysis of power expressed at the basin 
level in a transboundary water context. The politics of scale literature (applied to water governance analysis) allows identifying how these power dynamics can be socially-constructed at the state level and re-produced through social norm as a means to forward neoliberal discourses of water governance. Furthermore, I examine Misiones' level of adherence to the recently adopted Guarani Aquifer Agreement by analyzing Misiones' narratives about cooperation and power asymmetries in relation to discourses of sustainable development.

Because political actors within countries and their smaller sub-units (i.e. provinces and states) are able to re-shape the scale of governance through changes in state ideology, sanctioned discourses and practices (Feitelson and Fischhendler 2009; Lebel, Garden and Imamura 2005), which are reproduced through socio-natures' relationships as socio-cultural norms (by engaging citizens in new ideology and conceptualizations), this study largely relies on the analysis of discourse in the water sector in the province in Misiones

Through these three literatures, I support the argument that Misiones' practices of water marketization are neither sustainable nor compatible to the principles of "equitable and reasonable" utilization and "the obligation not to cause significant harm" to other states involved within a capitalistic logic of governance. Furthermore, I argue that these processes are occurring within an unsustainable framework of transboundary groundwater governance for the Guarani Aquifer System, measured through Misiones' lack of adherence to the GAA. Given the arguments made above, I argue that current emerging practices of water marketization in the province of Misiones are not conducive to the sustainable transboundary groundwater governance of the GAS, whose scale of governance is delimited by the GAA and its main principles of reasonable and equitable utilization, cooperation and the obligation not to harm other sovereign states involved. In addition, through the case of Misiones, I show that the GAA is not a functional 
scale of transboundary governance and suggest that further related research through case studies would supplement this research.

I frame these three literatures through the lenses of political ecology approach of a "conservation and control" thesis, through which the central analysis is the "implementation of efforts to preserve" natural resources (Robbins 2004, 149). The sustainable governance of the Guarani Aquifer System is dependent upon The Guarani Aquifer Agreement, a legal instrument (treaty) that delimits rules and regulations for the preservation of the aquifer, whose control is determined by its enforcement. Furthermore, I employ a political ecology approach in this analysis because of the recent call from critical geographers to situate resource governance analyses within historical, socio-economic and political contexts (Bakker 2003; Budds 2004).

\section{The Political Ecology Approach}

The application of a political ecology approach to the analysis of water neoliberalization is of particular relevance because it allows for an analytic framework that not only acknowledges water in its material form but that it also incorporates the historical, political and socio-economic contexts of capitalistic societies. The "neoliberalization of nature" literature is largely dominated by a political ecology approach which emphasizes the role of power structures and forces (such as

political, ideological and socio-economic) in shaping "socio-nature" relationships through shifts in resource governance and its resulting re-distributive allocation preferences (Heynen and Robbins 2005; Mansfield 2007; Budds 2004).

As described by Bakker (2010), analyses on the neoliberalization of nature include transformations that range from minerals resources to fisheries, forests, gas, oil, water and even the human (through the commodification of human organs) (Bridge 2002; Mansfield 2004; 
Sawyer 2004; Bakker 2005; Scheper-Hughes 2005; McCarthy 2006; Perreault 2006). These changes generally occur through "local neoliberalisms," such as the case of water privatization and restructuring in Cape Town, South Africa, in which the local government encouraged international political intervention as a means to bring the city to international standards of governance (McDonald 2008). Therefore, these transformations occur within global hegemonic neoliberal frameworks "understood as the economic logic of globalizing capital and a force driving environmental change and governance" (Braun 2006, 644) mobilized by the individual politics of the ruling states. Consequently, this has shaped the politics of resource governance in distinctive and heterogeneous ways across space and time (Peck and Tickell 2002).

Neoliberalism is an economic and political project that seeks to rationalize governance by means of allowing the private sector to intervene in the management of resources through calculated market-based interventions signaled by global pricing, cost recovery, and cost efficiency. Neoliberalism treats nature as private property, "a form of dispossession that separates individuals from the means of production and forces them into wage labor" (Mansfield 2007, 396). As a rational process of intervention, neoliberalism seeks to institutionalize a "regime of truth" through the governance of resources in economic terms, maximizing their utility (Roberts 2008, 553). Furthermore, neoliberal projects are purported as the managerial solution to the "common property" problem, something exposed in Hardin's (1968) theory of "the tragedy of the commons" dilemma, "where the moral is that in the absence of clearly defined private property rights, individuals lack the incentives necessary to ensure the sustainability of resource such as land and water" (Roberts 2008, 539).

The neoliberalization of nature literature is part of a larger political ecology approach as it allows examining neoliberalization processes and its socio-water metabolic relationships within historical, geographical and politico-economic contexts. As Budds (2004) denotes, 
"It focuses on the (unequal) power structures and politics that underlie processes of environmental change and the sociopolitical and environmental implications of changes in the way that natural resources are allocated and managed, with particular emphasis on the interests of 'weaker' social actors" (Budds 2004, 325).

The political ecology approach is related to political economy, a broadly defined term which takes into account the wider systems of production in which societies are constrained, acknowledging the dialectical relationship of human-nature, with a particular focus on the social construction, materialism (e.g. capitalistic modes of production), and the dogmatic and abstract premises of these theorized systems (Greenberg and Park 1994).

"Simply put, a mode of production is a combination of social and material elements; these elements are constant, and include labor, technology and capital, but their interrelationships, combination, and recombination are in constant flux leading to differing ways of making a living from nature" (Robbins 2004, 46).

Analyses within political economy have also been acknowledged to have limitations as they are constrained within narrow materialistic systems of "modes of production." In this sense, political ecology offers a more inclusive approach to the political economy of resource governance, as (for the most part) it incorporates the political economy, the socio-economic and the political aspects of socio-natures which vary across space and time (Heynen and Robbins 2005). 


\title{
CHAPTER II
}

\section{LITRATURE REVIEW}

\author{
Introduction
}

To analyze Misiones' water marketization processes, I draw from literature in neoliberalization, and particularly, from a body of work on the "neoliberalization of natures" in environmental governance analysis (Bakker 2005; McDonald and Ruiters 2005; Goldman 2007; Swyngedouw 2005; Mansfield 2007; Perreault 2008). This literature selection shows how natural resources (such as freshwater) become targets of capitalist strategies through the mediums of property relations, governance, enclosure and valuation expressed through neoliberal projects such as privatization, marketization and commodification (Budds 2004; Heynen and Robbins 2005; Mansfield 2007; Bakker 2005; Bakker 2010); and it elucidates how different forms of neoliberal processes redefine social and nature relationships through shaping the contours of regulatory frameworks, property rights, and state ideology around resource governance (Larner 2000; Budds 2004; Heynen and Robbins 2005; Roberts 2008; Ioris 2010). Central to this literature, is also the role of social construction and discourse in enabling neoliberal processes of governance (Bakker 1999; Feitelson and Fischhendler 2009) through which specific knowledge becomes integrated in social norm as "authoritative knowledge" (Goldman 2001; Goldman 2007).

Because Misiones' water marketization is occurring within a transboundary groundwater framework of governance, which is demarcated by the Guarani Aquifer Agreement (GAA), I draw from a collection of literature regarding discourse on widely accepted notions and critiques 
on the concept of sustainable development and the main principles of this framework (equitable and reasonable utilization, cooperation and the obligation not to harm other states involved) applied to transboundary surface groundwater analysis (Dellapenna 2001; Puri and Aureli 2005; Linton and Brooks 2011; McCaffrey 2011; Dellapenna 2011). These principles, which derive from an evolution of international water law regulations and guidelines, have been widely critiqued for its broadness and ambiguity, as states can interpret policy subjectively according to their political agenda.

The vagueness found in the concept of sustainable development (Livesey 2002; Parris and Kates 2003; Hajer and Versteeg 2005) and the main principles of the United Nations International Law Commission (UNILC) on the Law of Transboundary Aquifers (Dellapenna 2001; Fischhendler 2008; Linton and Brooks 2011; Brooks and Linton 2011; McCaffrey 2011), creates new spaces for contestation through which states forward selective knowledge in the form of discourses to legitimize their practices (Hajer and Versteeg 2005; Goldman 2007). However, I argue that although these terms are broadly defined, they also offer some basic grounds for accountability. Therefore, this literature provides an analytical background of the main UNILC Law of Transboundary Aquifers and GAA principles and the sustainable development framework in which they are embedded. In turn, the analysis of Misiones' discourses of water governance will allow to measure if Misiones is currently following these principles, and what do these discourses speak of in relation to the sustainable governance of the Guarani Aquifer System (GAS).

Lastly, I draw from a third conceptual framework on the "politics of scale" literature widely theorized by social geographers (Smith 1992; Swyngedouw 1997; Marston 2000; Brenner 2001; McCarthy 2005), which allows situating this study within a constructionist approach of scale. This theoretical framework rejects the idea that scale is ontologically given, fixed or 
hierarchical and advances the idea that scale is socially constructed according to the decisionmaking processes occurring at a given place and time (Brown and Purcell 2005; Norman, Bakker and Cook 2012). As the governance of the GAS has been delimited by the GAA as the primary scale of governance, this literature allows analyzing how this scale can be socially constructed by decision-making processes according to the state's interests (Marston 2000; Brenner 2001; Lebel, Garden and Imamura 2005).

Since Misiones' discourses of water governance convey a narrative of power asymmetries of resource utilization and issues of cooperation among sovereign states involved, I also employ an analytical framework on hydro-hegemony within International Relations (IR), largely utilized in transboundary water analyses of conflict and cooperation (Wolf, Yoffe and Giordano 2003; Zeitoun and Warner 2006; Zeitoun and Allan 2008; Zeitoun and Mirumachi 2008), to analyze how these narratives get reconstructed at the local level to forward particular authoritative knowledge. This framework assesses how different types of power enacted through state sovereignty intervene in the expression of hegemonic behavior at the basin level, and how weaker states may both be affected or benefited from this power play. Furthermore, in addition to these theoretical and analytical frameworks, I provide an analysis of cooperation within the International Relations literature, and as defined by the GAA, to assess the level of Misiones' adherence to this treaty, revealed through discourses of water governance.

These three literatures address the main questions of: What do Misiones' discourses of water governance speak of in relation to Misiones' level of adherence to the GAA? How do these narratives simultaneously enable neoliberal process of water governance through which commodification is inserted and reproduced through social norm? What scales are enabled and/or deterred through this process? And what does this reveal in terms of the sustainable development of the Guarani Aquifer System? 


\section{Neoliberalization of the Water Supply Sector}

In this section I seek to situate this study within the neoliberalization literature, focusing on a body of work on the "neoliberalization of natures" in environmental governance analysis, largely dominated by the work of critical geographers on resource governance. This body of work is relevant to this analysis, because it addresses the role of neoliberalization processes on resource governance with a particular focus on how these processes work to transform nature and livelihoods via new scripts of property relations, which vary according to the different type of neoliberalization process encompassed (i.e. privatization, commodification, commercialization, marketization, etc.) (Shiva 2002; Budds 2004; Bakker 2005; Swyngedouw 2005; Perreault 2006; Mansfield 2007; Goldman 2007; Perreault 2008; Bakker 2010).

To better situate this analysis, I first demarcate some particular distinctions about this case. Misiones' most recent water reform, although embedded in a neoliberal framework of water governance, is distinctively different from other cases analyzed in the literature by primarily two conceptualizations. Firstly, most case studies on the "neoliberalization of water" literature focus in analyses within the water sector rather than in the wider scale of water governance (Budds 2004; Swyngedouw 2005; McDonalds and Ruiters 2005; Perreault 2006; Bakker 2007; Bakker 2013). Secondly, this literature presents its cases through neoliberal transformations enacted by the "private sector" as the sole mechanism through which market-oriented practices can be introduced (Budds 2004; Swyngedouw 2005; Bakker 2005; McDonald and Ruiters 2005; Mansfield 2007; Roberts 2008). In this sense, Misiones' recent water marketization does not follow the typical pathway of water neoliberalization, as it is directly encompassed by the state in the character of a private corporation, and occurs within the wider scale of water governance. In addition, this case contests some of the premises and binaries established within this literature 
which derive primarily from hegemonic extralocal neoliberal projects of resource governance (Peck and Tickell 2002; Jessop 2002; Roberts 2008).

\section{Neoliberalism and Neoliberalization}

The term neoliberalism (in its broad sense) has been widely employed to describe the radical changes enabled by a series of scripted mechanisms, in the form of specific rules and discourses contained within the political, regulatory and governmental realms, which strongly encourage free-market regimes through environmentally-oriented discourses and strategies, and the promise to effectively manage resources through self-regulated markets (Peck and Tickell 2002; McCarthy and Prudham 2004). For example, privatization often occurs through a script of state de-regulation and the subsequence transference of property rights to the private sector (Mansfield 2007; Roberts 2008). In this sense, neoliberalism encapsulates different and distinctive processes which cannot be regarded as one monolithic instance, but as complex, multidimensional and spatio-temporal processes. As Tom Perrault remarks, “...neoliberalism is best thought of not as an end product, but as a variegated and highly contested process riven with internal contradictions" (Perreault 2006, 153).

As a radical economic and ideological project during the 1980s and 1990s, neoliberalism sought an all-encompassing de-regulation of primarily state-regulated services such as oil, gas and water (Bakker 2005; Sawyer 2004; Perreault 2006), through the "dismantling" or "roll-back" of the state, and its more local administrative jurisdictional units. Neoliberalism functioned as a globalized politico-economic intervention which transformed space and its socio-nature relationships through discourses of state failure and anti-collectivist modes of governance (Peck and Tickell 2002; McCarthy and Prudham 2004; Roberts 2008). 
Neoliberalism is most often associated with the 1980s and the Reagan and Thatcher administrations, later shifting into a more formalized set of practices through the Chicago School and the "Washington consensus" during the 1990s (Peck and Tickell 2002, 380; McCarthy and Prudham 2004; Jessop 2002). "A key component of the Washington Consensus is the privatization of state assets, particularly those that subsidize users and fail to operate along the lines of full cost recovery" (Roberts 2008, 539). In this regard, neoliberalism is considered a freemarket based theory which gained global hegemonic recognition as the dominant ideology of the 1990s through the paradoxically "greening" politics of capitalism (intervening in processes of resource governance) "to resolve critically urgent environmental crisis" (Peck and Tickell 2002; McCarthy and Prudham 2004; Goldman 2007; Bakker 2010, 715). This form of neoliberal intervention has been more recently coined "market environmentalism," (as well as "greenneoliberalism and "liberal environmentalism"), an economically-driven regulatory mechanism which proposes free-market principles as the best managerial solution to contemporary environmental crises (Bakker 2007, 431).

The term neoliberalism has been contested in the literature in various ways. First, the distinction between neoliberalism and neoliberalization has been denoted in the literature for a better understanding of this terminology. In the broad sense, neoliberalism has been ascribed to different transformations that fall under the umbrella of one neoliberalism. Larner (2000) for example, provides three distinctive examples: neoliberalism as policy, as ideology and governmental frameworks. Critical to this analysis is the concept of neoliberalism as a regulatory project, which seeks the transformation of socio-natures through de-regulation and re-regulation of services (Peck and Tickell 2002). Through re-regulation, new property relations are rescripted, redefining the rules of access and use to natural resources. 
The term neoliberalization has been denoted as the process through which different socio-natures are transformed by distinctive neoliberal projects that fall under the broad term of neoliberalism. This process should not be considered an "end state" but as a continuous process contingent upon historical and geographical contexts (Peck and Tickell 2002; Heynen and Robbins 2005; Roberts 2008). The importance of outlining the concept of neoliberalization as a process in this analysis is rooted in its essential mechanism to transform socio-nature (Bakker 2005; Perreault 2006; Mansfield 2007). A clear example is Perrault's (2006) analysis on the water and gas resource struggles that took place in Bolivia in 2000 and 2003, respectively, which stemmed from two distinctive instances in which transnational corporations attempted to intervene in Bolivia's resource governance through de-regulation and privatization. Furthermore, these transformations can be examined through shifts in discourses and practices in relation to market-oriented trends, the role of the state vis-à-vis the citizen and the simultaneous considerations towards environmental protection and preservation (Bakker 1999; Blatter and Ingram 2001; Peck and Tickell 2002; Shiva 2002; Budds 2004; Swyngedouw 2005; Whiteford and Whiteford 2005; Feitelson and Fischhendler 2009).

\section{Neoliberalization of the Water Supply Sector}

In the water supply sector these transformations have been made visible through changes in regulatory frameworks of water governance during the decades of rising neoliberalism of the 1980s and 1990s. At the global level, this period was encompassed by dramatic institutional changes in the restructuring and re-scaling of the water supply industry, and had its official historical marking in 1992 through the fourth principle of the Dublin Statement on Water Sustainable Development, 
"Water has an economic value in all its competing uses and should be recognized as an economic good. Within this principle, it is vital to recognize first the basic right of all human beings to have access to clean water and sanitation at an affordable price. Past failure to recognize the economic value of water has led to wasteful and environmentally damaging uses of the resource. Managing water as an economic good is an important way of achieving efficient and equitable use and of encouraging conservation and protection of water resources" (UNESCO 2014).

The Dublin Principles not only precipitated a re-definition of water from "human right" to an "economic good" (Conca 2006), but they also underpinned a series of theoretical confrontations within the analysis of water governance regulation which contested the role of the state as the primary institution responsible for the governance of water resources (particularly the water supply sector and its related public services). This re-conceptualization of water as an "economic good" essentially naturalized the "free-market" as the only regime through which water resources could (should) be governed. This led to the subsequent debate initiated by proponents of market environmentalism, which purported the state as inefficient and unable to manage resources according to market principles (Peck and Tickell 2002; Bakker 2007).

This debate was partially based on the state's putative role as a proponent of Keynesianwelfarist regimes, prioritizing the creation of labor and the protection of the citizen over marketefficiency, global pricing signals and full cost recovery, and not necessarily recognizing water as an economic good. Through this new "scripting" principle and "way to perceive water," global neoliberal agenda was mobilized, through cases of de-regulation and privatization of the water sector, seeking to transform Keynesian-welfarist nation-states and their local administrations into market-oriented regimes (Peck and Tickell 2002; Jessop 2002; Bakker 2007; Roberts 2008). 
Producing "Authoritative" Neoliberal Knowledge in the Water Supply Sector

Along with this new re-conceptualization of water (from human right to economic good) and water policy reform agenda (neoliberal governance of the water supply sector) was the emerging discourse of water scarcity. The water scarcity discourse was instrumental in mobilizing neoliberal agendas through the discursive assertion that water is an inherently scarce resource that should be treated as a commodity and should follow market signals for its most efficient allocation. In this sense, this was a successful "manufactured" discourse which generalized "relative scarcities" narratives into "absolute scarcity" discourses to mobilize neoliberal agendas and their technocratic economic projects (Blatter and Ingram 2001; Shiva 2002; Rijsberman 2005; Heynen and Robbins 2005; Conca 2006; Bakker 2007; Mansfield 2007; Goldman 2007). For example, Mehta uses the case of Kutch in India to illustrate how water scarcity is produced by different political actors to forward their political ends such as the construction of hydro-related works (Mehta 2003).

Along with the water scarcity discourse, the spread of global neoliberal agenda was enabled by producing "specific authoritative knowledge" and "criteria" and in some cases "its omission" in relation to resource governance and environmental concerns. This "knowledge" (and lack thereof) was in most cases introduced by transnational groups, non-governmental organizations (NGOs), think tanks and lending institutions such as the World Bank (WB), the International Monetary Fund (IMF), the Organization of the American States (OAS), the World Trade Organization (WTO) and the United Nations (UN), among others (Whiteford and Whiteford 2005; Shiva 2002; Goldman 2001; Goldman 2007; Blatter and Ingram 2001).

Through the central discourses of water scarcity (Bakker 2007; Mehta 2003), binarybased market-efficiency and Keynesian-welfarist (which purported the private sector as efficient 
and the Keynesian-welfarist state as inefficient) (Peck and Tickell 2002; Swyngedouw 2005; Bakker 2007), and water as an “economic good” (Budds 2004; Bakker 2007; Goldman 2007) neoliberal agenda was mobilized. Another discourse that facilitated these transformations was the discourse of private-public partnerships (PPPs). This discourse was largely mobilized through the Johannesburg World Summit on Sustainable Development (WSSD) in 2002, as a means to improve legitimacy in environmental governance and better water access "for all" by incorporating the private sector in the water sector "whereby the state continues to own assets and is involved in the monitoring and decision making of the service delivery, but the actual operations and planning of water services are undertaken by the private entity" (McDonald and Ruiters 2005, 2; Goldman 2007).

In this respect, this study centers its methodological analysis within the "production of knowledge" in Misiones' water governance, intrinsically interwoven in socio-cultural norms through distinctive discursive instances (such as acceptance, rejection and/or normalization), and simultaneous shifts in state ideology and practices (Blatter and Ingram 2001; Feitelson and Fischhendler 2009). In doing so, this analysis focuses on those particular emerging discourses at the state level, which seek to naturalize new regulatory reforms through the simultaneous introduction of selective authoritative knowledge within socio-cultural norms and thus, delineate how water should be perceived, allocated, governed and controlled. Particularly relevant to the case of Misiones, is the role of the provincial government in producing new knowledge and discourses that naturalize new strategies of capital accumulation such as the commodification of water. 


\section{Neoliberalization, Water and the State}

Neoliberalization entails the "dismantling" of the state (or province) through the softening of the rules for intervention in the water supply sector and its related services. This downsizing of the state is usually accompanied by the selling of or transference of property rights from the public to the private sector (in the form of partial/full privatization or concession) which allowed the participation of other actors such as NGOs, citizen's groups, and particularly the private sector, in resource governance (Perreault 2005; Swyngedouw 2005; Bakker 2005; Bakker 2007). In the water sector, these projects consist of privatization, marketization, commercialization and commodification (among others) of the water supply and sanitation industry (Bakker 2010). Similarly to cases in the literature, Misiones' water reform involves a the commodification of water through a transfer of private rights to the state-owned water corporation Aguas Misioneras Sociedad del Estado (AMSE) (Law No. 149) for the means of dispossessing any territorial freshwater resources for AMSE's new bottling water industry. Differently from other cases in the literature, Misiones' case does not involve the downsizing of the state, but on the contrary, entails an even more centralized regulation of water services through a stronger state inherence in water-related governance processes.

In relation to water governance, Karen Bakker (2007; 2010) has provided a useful typology of water reforms in the water sector. This has provided useful insights to the constitutive elements of each of these processes, as well as the scale of intervention (at the institutional, organizational and/or governance level). In particular, Bakker provides the grounds for three main areas upon which neoliberal interventions occur,

"Resource management institutions are the laws, policies, rules, norms and customs by which resources are governed. Resource management organizations are the collective social entities that govern resource use. And resource management governance is the process by which organizations enact management institutions, the practices by which, in 
other words, we reconstruct and administer the exploitation of resources" (Bakker 2007, 434).

For example, privatization entails an institutional reform intervening in private property rights. However, marketization occurs within the continuum of resource governance and intervenes in processes related to resource allocation taking into account market pricing signals (Bakker 2007; Conca 2006). Differently, the corporatization of water entails an organizational reform and "involves changing public institutional structures to incorporate private sector principles in the provision of services" (McDonald and Ruiters 2005, 171; Conca 2006; Bakker $2007,435)$. From all these types of transformations, privatization is the most common neoliberal project carried out in the water supply sector (Bakker 2005; Perreault 2005; Swyngedouw 2005; Budds 2004; Shiva 2003). However, while this typology serves as clarification for each type of process, these transformations often occur simultaneously (Mansfield 2007; McDonald and Ruiters 2005).

Particularly significant to the case of Misiones is the analysis of water marketization and commodification. In this respect, Misiones' recent emerging practices of water marketization not only occur within the water supply sector (indirectly), but involve the wider scale of water governance. In addition, Misiones' water marketization has been accompanied by a simultaneous re-affirmation of provincial public domain rights (already established in Argentina's National Constitution) of superficial, pluvial, and groundwater resources through re-regulation. In other words, although granted at the national level through the National Constitution Law No. 124 (the public domain of Argentina's provinces over their territorial water resources), Misiones' recent re-regulation extends these rights to the state-owned water bottling corporation AMSE through the law No. 149 (Aguas Misioneras 2014). In doing so, this property relation entails an extension of rights to AMSE for the extraction, bottling, distribution and commercialization of superficial, 
pluvial and/or groundwater (including GAS groundwater) for any use other than for the water supply sector.

Although Misiones' re-regulation for all water resources does not directly involve the water supply sector, the law Guarani Aquifer System and Groundwater (Sistema Acuífero Guaraní y Aguas Subterráneas) No. 95 shows that these processes are intertwined within the water supply sector indirectly through public financing and cross-subsidies for the water supply sector. Furthermore, AMSE's water commodification processes have been legitimized as the necessary source of public financing for water-related infrastructure for the water supply industry (including the private sector) and mega hydro-works such as the construction of dams, purported as "necessary" projects to provide safe water access "to all" (Goldman 2007; Bakker 2007) and for the proper functioning of the water supply sector.

In other words, AMSE's commodification has been advanced through a "highly technocratic-managerial" discourse (Feitelson 2002, 299), as the sole mechanism through which social needs can be met. Therefore, AMSE's commodification involves a highly technocratic culture of building works as the only means through which provincial progress can be achieved. However, within a capitalistic logic of water governance, neoliberal projects of governance in the water sector have not necessarily achieved social ends nor have prioritized sustainable processes of governance, but on the contrary, have precipitated opposite effects (Shiva 2002; Mehta 2003; Budds 2004; Goldman 2007; Mansfield 2007; Roberts 2008; Ioris 2010). Because Misiones’ water commodification is constrained within Misiones' water governance processes, marketizing its processes, I now turn to the analysis of water marketization and commodification to better understand what these processes involve. 


\section{Marketization of Water}

As defined by Ken Conca, water marketization refers "to the process of creating the economic and policy infrastructure for treating water as a market commodity" (Conca 2006, 215). Different from privatization, which entails a transformation at the institutional level through the transfer of property rights, marketization is a more flexible concept. Water marketization involves an intervention in resource governance (not at the institutional or organizational level), which might occur at multi-scalar levels (e.g. water supply sector, water sanitation services, water exports, etc.). "Marketization focuses on the question of how to value bulk water resources, and allocate them across categories of social use (industry, agriculture, municipalities, in-stream uses)" (Conca 2006, 216). In other words, marketization involves the insertion of market-oriented signals in processes related to water resource allocation (McDonald and Ruiters 2005; Conca 2006; Bakker 2007)

It is under this definition of water marketization that I situate Misiones' recent practices of water commodification. Most particularly, I seek to present this case as a precursor of new counter-emerging forms of neoliberal transformations in response to privatization, which contest established binaries (such as public vs. private) and analyses that situate this concept within the water sector realm and private sector interventions. Furthermore, the case of Misiones operates within a "second wave of neoliberalism" (neoliberalization projects in response to privatization) (Smith 2004, 375), as the state seeks strong protective measures of re-regulation following a period of de-regulation and privatization. 


\section{Commodification of Water}

Current analysis on the commodification of water, within the "neoliberalization of nature" literature is largely focused on its relation to the privatization of the water supply industry (Bakker 2003; Bakker 2005; Swyngedouw 2005; Heynen and Robbins 2005; McDonald and Ruiters 2005). Within this analytic framework, commodification entails the process by which bulk water is treated as an economic good through, for example, regulated metering. This particular form of commodification of water (regulated metering) usually implies full privatization. On the other hand, partial privatization entails the private management of the water supply sector, usually occurring in the form of "concessions" (a type of public-private partnership through which private corporations manage the infrastructure of state water services provision under long-term agreements) and not necessarily involving commodification (albeit some forms of concessions may reach full privatization as per their contracts) (Bakker 2003; Bakker 2005).

In "neoclassical economic terms" commodification involves exchangeability. This may occur through the selling of a commodity for money or trading of one commodity for another (McDonald and Ruiters 2005, 19). Natural resources have long been treated as commodities dating back at least to colonization (Glassman 2006). Human geography analyses on capitalism, through the lenses of Marxist analysis on the commodification of nature [Marx 1867] has shed light on commodification processes within contemporary capitalist societies (Harvey 1975; Castree 2003).

This analysis is focused particularly on the re-workings of some of the Marxian theoretical concepts on commodification (of nature), and particularly on commodities which, as per contemporary analysis on Marx's writings, is the product of "social relations" (through labor), where nature is just a mere category. Noel Castree denotes in this respect, "Marx's principal 
intent, according to several generations of commentators [...], was to show that in capitalism exchangeable goods are nothing but an alien and displaced form of social labor" (Castree 2003, 278). In an attempt to adapt this concept of commodification to contemporary capitalistic societies, Castree identifies six processes upon which commodification works its way through socio-nature relationships within current forms of capitalism. These processes are privatization, alienability, individuation, abstraction, valuation, and displacement. Critical to the analysis of Misiones is how water commodification is enabled through processes of privatization, individuation, and valuation.

In general, the process of privatization enables commodities to come into being by securing the transfer of entitlements to private parties through rights of dispossession and control, which in turn, enable alienation (the separation of the commodity from its source) and the exchange of commodities through money. Although emerging practices of water marketization in Misiones do not involve a privatization process, a similar form of entitlement has been secured through the re-regulation of freshwater resources and the subsequent transfer of some of these rights to the state-owned corporation AMSE. Similarly, individuation entails the "representational and physical act of separating a specific thing or entity from its supporting context. " This involves putting legal and material boundaries around phenomena so that they can be bought, sold, and used by equally 'bounded' individuals, groups, and institutions.” (Castree 2003, 279280). This process entails the isolation of a thing into a useful, concrete, and discrete entity, such as dissociating bulk (ground) water in to discrete useful units of premium bottled water. Lastly, in capitalistic societies, valuation comes into being through the medium of money. In this sense, objects become commodities when they are driven by profit (Castree 2003; Heynen and Robbins 2005). Karen Bakker has a useful definition on the multi-dimensional characteristics of commodification, 
"Commodification is a process whereby goods formerly outside marketized spheres of existence enter the world of money and, as such, is multidimensional: socioeconomic, entailing changes in pricing (pricing and the creation of price-signaling mechanisms), charging methods, and allocation and exchange mechanisms; discursive, entailing transformations in the identities of values ascribed to natural objects such that they can be abstracted from their own biophysical context, valued and displaced; and material, entailing physical interventions and adaptations such that desired nature(s) can be alienated from their ecological context as standardized goods, amenable to exchange"

(Bakker 2005, 545)

In addition, this analysis considers water commodification and re-regulation as two strategies of capital "accumulation by dispossession" (Harvey 2003; Glassman 2006) largely applied to cases of water privatization (Swyngedouw 2005; Bakker 2005; Bakker 2007;

Mansfield 2007; Roberts 2008). In Marx's own terms, the concept of primitive accumulation was based on capitalism's expansive need to acquire more capital through, what at the time of his writings was, "the looting of nature" during colonial imperialism (Harvey 2003, 145).

This analysis therefore investigates how newly emerging practices of water commodification and re-regulation in the province of Misiones and the Guarani Aquifer System get integrated into social norms through shifts in state ideology, discourses, and the production of new "authoritative knowledge" (Bakker 1999; Goldman 2001). Furthermore, this analysis elucidates how these processes legitimize new scales of water governance, which in turn, may pose significant to the sustainable governance of the GAS. 
Discourses of Sustainable Development and International Water Law Principles

\section{Introduction}

The analysis of Misiones' recent water marketization, commodification, and the reregulation of water resources is grounded in a transboundary groundwater governance analysis. As a sovereign state overlying the Guarani Aquifer, Misiones' recent activities of water neoliberalization are understood within the backdrop of groundwater governance for the GAS and its sustainable development framework: the United Nations International Law Commission (UNILC) Law of Transboundary Aquifers and its resulting Guarani Aquifer Agreement (GAA). The basis for this juxtaposition is that Misiones' water governance is constrained within this international-regional framework of governance. By signing this treaty, the four Mercosur sovereign nations are bound to specific guidelines for the joint management of the GAS (McCaffrey 2011).

The main questions this section addresses are: How does this legal framework provide a protective mechanism for the governance of the GAS? And how are Misiones' recent emerging practices of water marketization and re-regulation conducive to the sustainable governance of the GAS within this framework? Largely, the outcomes will vary across space given the heterogeneous socio-economic landscapes within this region. As stated before, states have the capacity to forward their own interests, agenda and to interpret policy according to their individual politics and ideology. They play a central role in reshaping the scale of governance (Young 1996; Norman and Bakker 2009; Feitelson and Fischhendler 2009; Lebel, Garden and Imamura 2005). 
The UNILC Law of Transboundary Aquifers has been acknowledged to be ambiguous and broadly defined (Linton and Brooks 2011; Hestermeyer et al. 2012), mainly because aquifers have different physical and functional hydrological characteristics (Eckstein and Eckstein 2005; Kebede, Ketema, and Tesema 2010). In addition, the broad language dominant in international water law does not necessarily bind states to specific tasks and activities of control and enforcement, but rather enable new spaces of contention within the term "sustainable development," a terminology that conveys great contradictions in itself (see Redclift 1987). This ambiguity and broadness in international water law reflected in many international water treaties (Fischhendler 2008) has further enabled heterogeneous and socially-constructed scales of governance across nation-states and their smaller jurisdictional units.

Misiones' re-affirmation of public domain rights over its territorial freshwater resources is in direct tension with the sovereign rights of the UNILC Law of Transboundary Aquifers because these two types of rights are set to function differently at the international and intranational scales. Public domain rights (dominium) function within the intra-national level and are contained within sovereign rights (imperium); and thus, sovereign states have the capacity to pose restrictions to property rights holders (Young 1996; Feitelson and Fischhendler 2009; Pochat 2011). Furthermore, because the GAA was signed at the "Parties" level (countries) rather than at the state level (as originally delineated by the UNILC Law of Transboundary Aquifers), and although the province of Misiones has full sovereignty over the GAS, the national scale delimited through the GAA contrasts with Misiones' scale of governance delimited by provincial public domain rights (Feitelson and Fischhendler 2009; Misiones Cuatro 2010; UN 2013d).

I seek to present this literature within the context of the UNILC Law of Transboundary Aquifers (and the GAA) and its main principles of equitable and reasonable utilization and the 
obligation to cooperate and to not cause harm among sovereign states. These principles demarcate the basic guidelines for the join management of the GAS for the prospects of its preservation.

\section{Article 4 and 5: Equitable and Reasonable Utilization}

The principle of "equitable and reasonable utilization" is one of the central principles of the recently codified UNILC Draft Articles on the Law of Transboundary Aquifers. Water law scholars have identified this principle to be complex, ambiguous, and difficult to enforce. Dellapenna (2001) provides an account of this principle's evolution within customary international law (the law that emerges through state's practices and a series of claims and counterclaims), in which the riparian position of the state (the position the state holds across or along the river), is central. To solve issues of rights among the upper and lower states, like "prior appropriation" rights, the concept of "restricted sovereignty" or "equitable utilization" evolved to balance rights over surface waters (Dellapenna 2001, 270). This principle became central to the United Nations Convention on the Law of the Non-navigational uses on International Watercourses codified in 1997 for surface waters, and was later incorporated in the UNILC Draft Articles on the Law of Transboundary Aquifers in 2008. The principle No. 4 of the Draft Articles, "equitable and reasonable utilization," reads as follows:

Aquifer States shall utilize transboundary aquifers of aquifer system according to the principle of equitable and reasonable utilization as follows:

(a) they shall utilize transboundary aquifer or aquifer systems according to the principle of equitable and reasonable accrual of benefits therefrom to the aquifer States concerned;

(b) they shall aim at maximizing the long-term benefits derived from the use of water contained therein; 
(c) they shall establish individually or jointly a comprehensive utilization plan, taking into account present and future needs of, and alternative water resources for, the aquifer States; and

(d) they shall not utilize a recharging transboundary aquifer or aquifer system at the level that would prevent continuance of its effective functioning.

In addition, the first section of the article 5 (5.1) provides the most relevant factors to take into account when examining "equitable and reasonable utilization" and reads,

1. Utilization of a transboundary aquifer or aquifer system in an equitable and reasonable manner within the meaning of draft article 4 requires taking into account all relevant factors, including:"

From this list, I draw from this main factor:

(g) the availability of alternatives to a particular existing and planned utilization of the aquifer or aquifer system.

The last part of the second section of the article 5 (5.2) reads,

2. “...However, in weighing different kinds of utilization of transboundary aquifer or aquifer system, special regard shall be given to vital human needs."

This means that one of the measurements to evaluate equitable and reasonable utilization is in relation to how this groundwater is to be utilized. Article 5.2 clearly delineates that groundwater utilization should only take place when human needs are a priority and no other alternatives are available. In other words, when states explore alternatives, groundwater abstraction should only occur if no other freshwater resources (such as surface) are available. This is relevant to this analysis, as practices of water marketization and commodification emerging in Misiones does not follow this principle, because they prioritize the commodification of water (in the form of a water bottling business) rather than vital human needs. 
Despite on this principle's ambiguity and lack of accountable and enforceable strength, this analysis will be based on the minimum grounds this principle functions; these ones can be understood in relation to the term equitable, which infers that states can harvest any amount of water as long as this amount is equitable (a quantity that should be defined among states). Therefore, equitable implies a relational process based on the mutual exchange of reliable information so that stakeholders can identify equitability. In other words, equitable cannot exist if there are quantitative and qualitative "unknowns" about the aquifer's exploitation level, degradation impact (pollution and contamination), soil change, deforestation, climate change as well as socio-economic variables. This principle is implicitly based on an inter-exchange of reliable technical information about the level of aquifer exploitation from each sovereign state. In this respect, "any process that promotes transparency and sharing of data among a wide range of stakeholders will be conducive to successful governance of transboundary aquifers" (Linton and Brooks 2011, 609). Arguably, unsuccessful and unsustainable governance could be understood in terms of lack of consistent data sharing among stakeholders.

Article 8 of the UNILC Law of Transboundary Aquifers explicitly demarcates, when referring to a "general obligation to cooperate" (article 7) "aquifer states shall, on a regular basis, exchange readily available data and information on the condition of their transboundary aquifers or aquifer systems, in particular of geological, hydrogeological, hydrological, meteorological and ecological nature and related to the hydrochemistry of the aquifers or aquifer systems, as well as related forecasts" (UN 2013d, 5). However, although the term equitable will be employed as the basic grounds for this analysis through its embedded relational meaning, this term poses great complications because "equitable utilization" does not necessarily entail that these processes will be sustainable. In other words, there could be extensive equitable competition among stakeholders leading to unsustainable governance while still adhering to this principle. This refers 
to a contradiction between this principle and the sustainable development framework embedded in the UNILC Law of Transboundary Aquifers.

\section{Article 6: Obligation not to Cause Significant Harm}

Along with the principle of "equitable and reasonable utilization," is the principle of "obligation not to cause harm" to other states involved. This principle is described as follows:

1. Aquifer States shall, in utilizing transboundary aquifers or aquifer systems in their territories, take all appropriate measures to prevent the causing of significant harm to other aquifer States or other States in whose territory a discharge zone is located.

2. Aquifer States shall, in undertaking activities other than utilization of a transboundary aquifer or aquifer system that have, or are likely to have, an impact upon that transboundary aquifer or aquifer system, take all appropriate measures to prevent the causing of significant harm through that aquifer or aquifer system to other aquifer States or other States in whose territory a discharge zone is located.

3. Where significant harm nevertheless is caused to another aquifer State or a State in whose territory a discharge zone is located, the aquifer State whose activities cause such harm shall take, in consultation with the affected State, all appropriate response measures to eliminate or mitigate such harm, having due regard for the provisions of draft articles 4 and 5.

Similarly to the concept of "equitable and reasonable utilization" the concept of "not to cause significant harm" to other states has also been contested in numerous ways (Dellapenna 2001; Linton and Brooks 2011) and is considered more problematic than the former, particularly because this term is subjective, varying according to the eyes of the beholder. Nonetheless, this study will draw from this principle to build an argument based on what "could" be considered "harmful," relying on a political ecology (and its political economy) analysis of resource utilization in the region of Misiones. 


\section{Transboundary Groundwater Governance}

For the purpose of this analysis, a distinction about the concepts will be made. Although the words "governance" and "management" are generally conflated, they are distinctive. Whereas "governance" refers to the wide process that involves structuring decision-making in the context

of both governmental and non-governmental institutions, "management" refers to the "nitty-gritty of resource operations" which often occurs at smaller scales (Linton and Brooks 2011; Brooks and Linton 2011, 433). It is therefore a distinction of sale.

Transboundary groundwater governance is a concept widely discussed in the literature (Dellapenna 2001; Puri and Aureli 2005; Campana 2005; Eckstein and Eckstein 2005; Jarvis et al. 2005) especially given the hitherto worldwide overreliance on groundwater resources for domestic, industrial and agricultural uses. Aquifers have been identified, for the most part, as readily available sources of good quality drinking water for human consumption (Puri and Aureli 2005). Human population and economic growth have exacerbated groundwater utilization which has contributed, in many cases, to the depletion and contamination of many aquifers around the world (Eckstein and Eckstein 2005).

There are approximately 263 river basins identified in the world. These hydrological units do not necessarily match exogenous man-made political boundaries. Most river basins are transboundary; hence, their watercourses and groundwater resources often cross international political boundaries (Puri and Aureli 2005; Jarvis et al. 2005).

"When describing transboundary, the term 'transboundary' is often used synonymously with 'transnational,' 'international or 'internationally shared." In the context [of this theme issue], 'transboundary ground water' refers to a continuous ground water reservoir (generally an aquifer) that underlies or whose water flows beneath two or more political jurisdictions and can be exploited by each jurisdiction" (Campana 2005, 646). 
Many issues are involved in transboundary groundwater management. First, different from surface water, groundwater is often found invisible, which makes this freshwater difficult to assess and analyze quantitatively and qualitatively. Competition for groundwater is also less evident than that of surface water. Competition in the form of excessive il[legal] drilling of water wells for domestic, agricultural and industrial use and lack of control and enforcement is one of the main problems related to groundwater management (Vaux 2011). Pollution is another influential factor playing into the longevity and preservation of groundwater bodies and so is its assessment, monitoring, and control (all management-related interventions). "Groundwater pollution occurs when hazardous substances come into contact and dissolve in the water that has soaked in the soil" (EPA 2013). Polluted aquifers not only represent vast economic losses, but are in most cases irreversible (Vaux 2011).

One of the most challenging tasks of transboundary ground water management is “assessment and evaluation," not only of aquifers' biophysical characteristics but of their related socio-economic impact (utilization and degradation of groundwater resources) (Puri and Aureli 2005, 664; Kebede, Ketema and Tesema 2010). This task is an even greater challenge as not all data is often readily available. In best case scenarios, when available, this information is partial and heterogeneous across the multi-jurisdictional units of governance. As Puri and Aureli assert,

"Scientific correlation of transboundary hydrogeology is often deficient, and shared, sustainable production rates remain uncertain because of weak institutions and a lack of capacity...Transboundary aquifer management is still in its infancy, since its evaluation is difficult, suffering from a lack of institutional will and finance to collect the necessary information. Although there are fairly reliable estimates of the resources of rivers shared by two or more countries, no such estimates exist for transboundary aquifers" (Puri and Aureli 2005, 664).

A common belief is that because freshwater is generally a "renewable" resource (Manahan 2011) (it renews itself through the hydrological cycle), it will always be available in its 
liquid form and original chemical composition. However, freshwater is a finite resource whose availability will continue to be stressed as human population increases. By 2025 , it is estimated that almost $70 \%$ of the world's population will have moderate to severe water shortages (Clini, Musu and Gullino 2008; UN 2013c). Strikingly, this estimate only takes into account water consumption per capita in relation to the total population estimate, which does not necessarily consider the associated agricultural and industrial pollution related to this increase. Furthermore, some aquifers or sections of aquifer systems can contain "non-renewable" water, in the form of "fossil" water. This type of groundwater has a very slow recharge rate, and if degraded or overexploited, can be severely compromised.

Legal frameworks for governing groundwater in the form of "aquifer or aquifer systems" have been developed after decades of international water law evolution regarding surface waters (Dellapenna 2001; Eckstein and Eckstein 2005, Puri and Aureli 2005). In 1997, the United Nations Convention of Non-navigational Uses of International Watercourses was crafted for the transboundary governance of surface waters. Eleven years later, the United Nations International Law Commission created 19 Draft Articles on the Law of Transboundary Aquifers (adopted by the General Assembly) utilizing the former instrument as a template for groundwater management. This was largely critiqued by hydrologists and water law scholars, as groundwater does not necessarily mimic surface water behavior, but rather groundwater is intrinsically related to it (Dellapenna 2001; Jarvis et al. 2005). Therefore, international water law poses limitations for the management of groundwater resources because it does not integrate them holistically with surface water but rather, treats them separately (Dellapenna 2001; Eckstein and Eckstein 2005; Dellapenna and Gupta 2008; Navarro Lins Brzezinski 2010; McCaffrey 2011). 
Introductory text of the UNILC Draft Articles on the Law of Transboundary

\section{Aquifers}

This first section of the UNILC Draft Articles on the Law of Transboundary Aquifers of the sixty third session (A/RES/63/124) denotes the need to create a legal framework for the governance of groundwater resources for several reasons. Among some of the main considerations mentioned, this framework acknowledges the increasing impact that freshwater demand has had on groundwater resources, and the importance in providing a protective framework for them. Other relevant text presented at the beginning of this legal document mentions "sustainable development" and the reaffirmation of the "United Nations Conference on Environment and Development of 1992 in the Rio Declaration on Environment and Development and Agenda 21," as two major components of this framework. These "texts" are an example of other broader narratives embedded in the UNILC Law of Transboundary Aquifers. Furthermore, this instrument provides the definitions for aquifer, aquifer systems, transboundary aquifers and states as the following,

(a) "aquifer" means a permeable water-bearing geological formation underlain by a less permeable layer and the water contained in the saturated zone of formation;

(b) "aquifer system" means a series of two or more aquifers that are hydraulically connected;

(c) "transboundary aquifer" or "transboundary aquifer system" means respectively, an aquifer or aquifer system, parts of which are situated in different States;

(d) "aquifer State" means a State in whose territory any part of a transboundary aquifer or aquifer system is situated; 


\section{Sustainable Development}

The UNILC 19 draft articles on Transboundary Aquifers have been framed around the concept of "sustainable development." More specifically, in the first section of this document, this paragraph reads as follows, "Convinced of the need to ensure the development, utilization, conservation, management and protection of groundwater resources in the context of the promotion of the optimal and sustainable development of water resource for present and future generations..." This last component of this text, "present and future generations" refers to a portion of the Brundtland definition on sustainable development, first known through the report Our common future, published by the World Commission on Environment and Development (WCED) in 1987. According to this definition, sustainable development refers to "development that meets the needs of the present without compromising the ability of future generations to meet their own needs" (IPCC 2013; World Bank 2013). Despite its acknowledged vagueness, this definition continues to be central to global environmental policy documents shaping the regulatory core of treaties, laws and environmentally-related economic projects (Mebratu 1998; Hajer and Versteeg 2005; Fischhendler 2008; Brooks and Linton 2011).

Because the concept of sustainable development is so broadly defined (Parris and Kates 2003) research on the sustainable development of transboundary groundwater bodies has fallen

prey of this terminology. Furthermore, transboundary groundwater law is still in its infancy (Puri and Aureli 2005), with only one successful case, the Guarani Aquifer Agreement, adhering to the UNILC guidelines for transboundary aquifers (Villar and Ribeiro 2011; UN 2013d). Recent research related to the "sustainable development" of transboundary groundwater bodies has emerged as an in-depth analysis and critique to the prescribed UNILC guidelines for transboundary aquifers (Linton and Brooks 2011; Stephan 2011; Eckstein 2012). Similarly, this study analyzes the level of applicability of this framework to the case of Misiones. Applied 
research on sustainable development within transboundary water governance has largely focused on disambiguating the main principles of international water law. As the case of cooperation between Turkey and Syria in the Ceylanpinar Aquifer (Oztan and Axelrod 2011), equitable and reasonable utilization in relation to patterns of water flow and utilization in the Palestine-Israeli case (Phillips et al. 2007), treaty flexibility in the Orange-Senqu River Basin, South Africa (Kristin, and Ashton 2008) and equitable and reasonable utilization, the obligation not to cause harm and cooperation in the Ganges Basin (Rahaman 2009).

Because both sustainable development and international water law guidelines for transboundary groundwater are ill-defined (Fischhendler 2008), so are the "measuring" indicators to evaluate sustainable development. Sustainability indicators "are quantitative measures selected to assess progress toward or away from a stated goal" (Parris and Kates 2003, 1). Indicators are not always defined nor prescribed through treaties, international agreements, and legal documents. In a transboundary context, indicators have to be agreed upon and developed by the parties involved through unanimous consensus and cooperation. In this sense, this study "measures" the level of Misiones' adherence to the GAA through the main principle of cooperation, which in turn reveals if such indicators are established among the parties involved, along with set short-and long-term goals, objectives and strategies. Brooks and Linton remark in this regard,

“... It is now more common for surface water bodies to be managed by sets of objectives that include not just minimum flow rates, but also seasonal changes in flows that emulate as much as possible, natural conditions. It is more difficult to develop parallel criteria for aquifers, but, at a minimum, falling water tables and increases in salinity or the presence of higher concentrations of trace elements are signs of impending trouble. As development pressures increase, it will be necessary to go beyond indicators to cumulative effects analysis [...] where those effects now include not just environmental but also socio-economic and cultural conditions" (Brooks and Linton 2011, 448). 
United Nations Conference on Environment and Development of 1992 in the Rio Declaration on Environment and Development and Agenda 21

In addition to the "Brundtland" definition on sustainable development in the UNILC Law of Transboundary Aquifers, other reference texts include the Rio Declaration and Agenda 21, both products of the United Nations Conference on Environment and Development held in Rio de Janeiro in June 1992. For the purpose of this analysis, I reproduce some of Rio Declaration's (UN 2013a) most relevant principles:

Principle 1. Human beings are at the centre of concerns for sustainable development. They are entitled to a healthy and productive life in harmony with nature.

Principle 2. States have, in accordance with the Charter of the United Nations and the principles of international law, the sovereign right to exploit their own resources pursuant to their own environmental and developmental policies, and the responsibility to ensure that activities within their own jurisdiction or control do not cause damage to the environment of other States or of areas beyond the limits of national jurisdiction.

Principle 3. The right to development must be fulfilled so as to equitable meet developmental and environmental needs of present and future generations.

Principle 4. In order to achieve sustainable development, environmental protection shall constitute an integral part of the development process and cannot be considered in isolation from it.

These principles are not exhaustive, but they are an example of the "hidden text" framing legal instruments related to transboundary water management. Furthermore, the Rio Declaration of 1992 and Agenda 21 follow the imperatives of what has been known as IWRM (Integrated Water Resources Management). IWRM has been denoted as "the process which promotes the coordinated development and management of water, land and related resources, in order to maximise the resultant economic and social welfare in an equitable manner without compromising the sustainability of vital ecosystems and the environment" (UN 2013b). 
"IWRM typically stresses three interrelated themes: recognition of the full range of social, economic, and ecological uses of water; 'cross-sectoral' water management, in the sense of integrating planning and practices related to agricultural, industrial, municipal, and ecosystemic or in-stream demands for water; and water management at multiple scales and levels, in the sense of coordinating local, regional, national, and transnational practices and institutions" (Conca 2006, 124).

The IWRM paradigm has shaped international water policy since the United Nations Water Conference of Mar del Plata in 1997, incorporating a holistic approach to the management of water resources. This approach suggests understanding "the right scale of water resource governance" (acknowledging its hydro-cycle) and incorporates, among other factors, the social, the regulatory, the economic and all the inter-related bio-social processes (Conca, 2006; UN 2013b).

\section{Article 7: General Obligation to Cooperate}

Conflict and dispute prevention and resolution have been a central issue to transboundary groundwater governance, particularly at the international level (Wolf 2007; Zeitoun and Mirumachi 2008). Cooperation has been identified as one of the most important mechanisms to prevent disputes and conflict over water resources access. In turn, the Article 7 of the UNILC Draft Articles incorporates the principle of "general obligation to cooperate" among states which reads as follows,

1. Aquifer States shall cooperate on the basis of sovereign equality, territorial integrity, sustainable development, mutual benefit and good faith in order to attain equitable and reasonable utilization and appropriate protection of their transboundary aquifers or aquifer systems.

2. For the purpose of paragraph 1, aquifer States should establish joint mechanisms of cooperation. 
As per the above description, the principle of cooperation is key to achieve the principles of "equitable and reasonable utilization" and the "obligation not to cause significant harm" to other sates involved. Cooperation, as described through the principle of equitable and reasonable utilization, refers to the joint governance among stakeholders which requires active data interexchange and monitoring. Therefore, the principle of cooperation is central to this study. This will allow understanding the contextual processes in which Misiones' marketization is contained. The principle of cooperation will be further analyzed through the International Relations (IR) literature.

\section{Scale of Governance}

Critical to this analysis is the scale at which a transboundary groundwater resource or aquifer system is most appropriately managed and governed (Lebel, Garden and Imamura 2005; Norman and Bakker 2009; Norman, Bakker and Cook 2012). Three key issues are identified in relation to the scale of governance in this study: 1) the most appropriate scale for transboundary groundwater governance in relation to Guarani Aquifer Agreement, 2) overlapping instruments, laws, treaties and regulations that create tension with the Guarani Aquifer Agreement, and 3) the social-construction of Misiones' water governance in relation to the Guaraní Aquifer Agreement. These issues will be further analyzed in the following literature. 
Power Asymmetries, Cooperation and the Politics of Scale

\section{Introduction}

Because the governance of the Guarani Aquifer System is determined by the GAA, a treaty that delimits the GAS' scale of governance at the international level, the examination of Misiones' cooperation among sovereign states (level of adherence to this treaty) within an international relations framework will allow understanding if this scale of governance is functional and if Misiones' practices of water marketization are occurring within a sustainable framework of transboundary groundwater governance. In doing so, this analysis investigates how emerging narratives in Misiones' water governance discourse about given power asymmetries and issues of cooperation at the basin level (among the sovereign states of the GAS) normalize new forms of neoliberal governance in the province.

This section draws from a hydro-hegemony analytical framework within the international relations (IR) literature which allows identifying how power dynamics play out in the arrangement of powerful (dominant) and weak (subordinate) users at the basin level (or resource domain). This framework provides knowledge on the power dynamics that most often intervene among sovereign users of shared water resources, which enables to understand how power relations play out in the production of new storylines emerging in Misiones. Power asymmetries have been largely addressed in transboundary water governance analyses (Dinar 2009) such as in the cases of Israel and Palestine (Zeitoun; Messerschmid, Attili 2009), Egypt and its neighbors (Allan 2009) and Turkey and Syria (Daoudy 2009). The hydro-hegemony framework has also been largely employed in transboundary water analysis (Zeitoun and Warner 2006; Zeitoun and Allan 2008; Zeitoun and Mirumachi 2008; Allan 2009). 
I also draw from an analysis of cooperation among sovereign states, as defined by the GAA, to provide the minimum operational grounds under which this treaty operates, which involves a set number of activities (through articles) prescribed to the sovereign states of the GAS to ensure its sustainable governance. This analysis illuminates Misiones' emerging storylines on cooperation and resource utilization asymmetries among sovereign states which further reshape and redefine the contours around practices of water marketization in Misiones, and the governance of the GAS.

To better understand international relations among the sovereign states overlying the Guarani Aquifer System post the adoption of the Guarani Aquifer Agreement (GAA) and within a framework of established mutual cooperation, I seek to draw specific elements from this literature. Broadly speaking, this literature largely assumes that cooperation and conflict lie along the same continuum (Furlong 2006) and have long been treated as a binary, when in reality there may be conflicts under cooperation frameworks and vice versa (Zeitoun and Warner 2006).

In the context of transboundary water analysis, analyses of conflict-cooperation have largely focused in highly contentious and drought prone transboundary water areas such as the Middle East (Zeitoun 2008; Feitelson and Fischhendler 2009; Oztan and Axelrod 2011). The conflict-cooperation approach within the international relations framework has been widely employed to understand the underlying factors eliciting conflict (e.g. war, cold conflicts) or warm relations (through treaties, laws, etc.) outcomes (Wolf, Yoffe and Giordano 2003; Zeitoun and Allan 2008; Zeitoun and Mirumachi 2008).

Within this analytic framework, I seek to ask a different type of question. In the context of the Guarani Aquifer System, the province of Misiones is both sovereign to the territorial portion of the GAS and has the public domain over its territorial water resources. As a sovereign province to the GAS, Misiones is represented through the nation of Argentina (as prescribed in 
the GAA) which acts, in this case, as the representative institutional entity for the sovereign provinces of the Argentine portion of the GAS (such as Formosa, Santa Fe, Corrientes, Chaco, Entre Rios and Misiones). In this context, I seek to ask the following questions: Within an established outcome of 'warm relations' and 'cooperation' under the GAA: What is Misiones' position with respect to international relations and cooperation with other sovereign states? What is the level of Misiones' adherence to this legal instrument? How is the GAA scale of governance reproduced in Misiones? In other words, the GAA demarcates that cooperation among sovereign "parties" (countries) is essential for the sustainable development of the GAS. Cooperation in this sense does not refer to a simple outcome of warm relations or peaceful relationship, but it explicitly invokes the sharing of scientific data among the parties involved (sovereign countries and their states) to determine what is "equitable and reasonable" in order to follow sustainable practices of governance.

I depart from an analysis of the term "cooperation" as employed in the Guarani Aquifer Agreement (GAA) treaty and the UNILC Draft Articles on the Law of Transboundary Aquifers. By signing the GAA, the parties involved (the countries of Brazil, Argentina, Paraguay and Uruguay) agree to a "cooperation framework" for the sustainable management of the GAS. Cooperation is therefore assumed through the signing of the treaty. But "real cooperation" in fact requires the enforcing of regulations and norms established in the GAA which involve active exchanging of scientific data and planning of joint activities. This requires that all the sovereign states (from all four countries) actively engage in international relations themselves or via representation by their national governments, providing accurate and updated information about resource utilization and potential estimated pollution from each of their sovereign provinces.

This examination is therefore queried at the most basic level. Cooperation is assumed in this analysis as all sovereign "parties" (countries) signed the treaty willingly. In this case, the 
definition of a "party" is clearly demarcated by the GAA, as each of the four Mercosur countries of Brazil, Argentina, Paraguay and Uruguay. Therefore, with respect to Misiones, the official institutional organization responsible for the management of the GAS is the national government of Argentina. Although this is fact, Argentina's provinces have been granted with the public domain over their water resources through the National Constitution article No. 124, which entitles provinces with the rights of ownership over their water resources. This first contradiction (between sovereign and public domain rights) is best reflected in the Article 1 of the GAA treaty,

"The Guarani Aquifer System is a transboundary water resource that integrates the sovereign territories of the Republic of Argentina, the Federative Republic of Brazil, the Republic of Paraguay and the Oriental Republic of Uruguay, which are the sole owners of this resource, and hereinafter will be referred to as 'Parties"' (GAA 2010, emphasis added; Villar and Ribeiro 2011).

Therefore, the GAA delineates the four Mercosur as the "sole owners" of this resource and as the parties responsible for the governance of the GAS hereafter, but at the national level in Argentina, this right has been transferred to the provinces. As the last portion of Argentina's National Constitution article No. 124 reads, "The original ownership over natural resources existing in their territory belongs to the provinces" (De Rosa 2011, 79).

\section{Cooperation}

As stated before, cooperation has been at the center of international relations analysis, and most recently employed in transboundary water studies (Wolf 2007; Zeitoun and Allan 2008; Zeitoun and Warner 2006; Zeitoun 2008; Blatter and Ingram 2001) as a means to identify conflict prevention tools. Cooperation in this sense reveals itself as an indicator of peaceful joint governance among the parties involved (Uitto and Duda 2002). International law under the 
framework of the UNILC has also incorporated the concept of cooperation as a basic principle to ensure the sustainable development of transboundary shared resources. Equitable and reasonable utilization in this sense cannot occur without joint cooperation. But cooperation under the international legal framework of the UNILC Law of Transboundary Aquifers involves a range of activities prescribed to the parties involved. Article 7 broadly delineates the scope of these activities,

"Aquifer States shall cooperate on the basis of sovereign equality, territorial integrity, sustainable development, mutual benefit and good faith in order to attain equitable and reasonable utilization and appropriate protection of their transboundary aquifers or aquifer systems" (UN 2013d, 5).

Article 8 provides an overview of the different activities that enable cooperation. This means that cooperation is not just a loose end to the agreement, but that it actually binds states to specific activities that enable sustainable governance in concrete terms. The four paragraphs of the article 8 are emphasized for the purpose of this study.

1. Pursuant to draft article 7, aquifer States shall, on a regular basis, exchange readily available data and information on the condition of their transboundary aquifers or aquifer systems, in particular of a geological, hydrogeological, hydrological, meteorological and ecological nature and related to the hydrochemistry of the aquifers or aquifer systems, as well as related forecasts.

2. Where knowledge about the nature and extent of a transboundary aquifer or aquifer system is inadequate, aquifer States concerned shall employ their best efforts to collect and generate more complete data and information relating to such aquifer or aquifer system, taking into account current practices and standards. They shall take such action individually or jointly and, where appropriate, together with or through international organizations.

3. If an aquifer State is requested by another aquifer State to provide data and information relating to an aquifer or aquifer system that are not readily available, it shall employ its best efforts to comply with the request. The requested State may condition its compliance upon payment by the requesting State of the reasonable costs of collecting and, where appropriate, processing such data or information. 
4. Aquifer States shall, where appropriate, employ their best efforts to collect and process data and information in a manner that facilitates their utilization by the other aquifer States to which such data and information are communicated.

Understanding 'cooperation' under the GAA guidelines and the existing contradictions between the GAA and the public domain rights granted at the provincial level in Misiones, will provide useful insights to the analysis of water governance discourses emerging in Misiones as emerging water narratives speak of dilemmas of cooperation arising from these contradictions in the scale of governance. Because Misiones' discourses of water governance convey a narrative of an existing power asymmetry of resource utilization among the four sovereign countries, as a means to support the claim that new water reform and marketization practices are occurring under a sustainable development context, I draw from the analytic framework on hydro-hegemony within the International Relations (IR) literature to further enrich this analysis.

\section{Hydro-hegemony and Power at the Basin Level}

Within a framework of transboundary water cooperation-conflict analysis, Zeitoun and Warner (2006) focus on the issue of control over shared water resources and the idea that this is best achieved through power-related strategies and tactics rather than through "water wars." Although the Guarani Aquifer System currently presents a cooperation status, Zeitoun and Warner's framework provides a useful analytic approach to understand Misiones' water-related discourses, as these carry narratives of existing power asymmetries of resource utilization among the four sovereign countries of the GAS. Furthermore this framework shows what types of power play may emerge among sovereign states at a given basin in a transboundary water context. 
In an abstractly observed world, conflicts are most often viewed as wars and cooperation as peace. But in most cases, as Zeitoun and Warner (2006) describe, conflicts can vary from highintensity war and cold conflicts to warm relations. And even in a state of apparent warm relations, underlying power asymmetries (economic, riparian position, etc.) often determine who gets to control the "rules of the game" in hydro-politics. In this case, this analysis is situated in a cooperation framework of seemingly warm relations given that the GAA was signed by the parties willingly. Therefore, this framework will only be employed as an informative tool about power dynamics in a transboundary basin, rather than viewing these power dynamics as monolithic knowledge, to identify how these dynamics may play in the narratives emerging in Misiones' discourses of water governance.

Zeitoun and Allan's (2008) framework of hydro-hegemony is a conceptual paradigm designed to analyze the presence of power as expressed through hegemonic behavior at the basin level. The main two components of this framework are the concepts of hegemony as theorized by Antonio Gramsci (1891-1935), which refers to the "maintenance of one social group's dominance over subordinate groups, accomplished through relations of consent and coercion" in a sustained manner through social relations (Ekers and Loftus 2008, 702) and Lukes' (2005) “three dimensions of power." Power is everything in hydro-politics. "Power is an effect of a myriad of relations. Not something that can be held" (Ekers and Loftus 2008, 700). As Swyngedouw (2004) remarks, "mechanisms of access to an exclusion from water lay bare political economic power relationships and positions of social and cultural power" (Swyngedouw 2004, 2).

Zeitoun and Allan (2008) describe, when citing Lukes' (2005) framework, three types of power that usually come to light when analyzing transboundary water conflicts and resolutions. The first type of power is a "material" or "hard" type of power. This can be best observed through the amount of military capacity and/or economic strength a particular state displays. In addition, a 
“state's riparian position could be considered an asset of 'hard' or 'structural' power" (Zeitoun and Allan 2008, 7). In a world of hydro-politics, riparian position plays an important role in determining who the hydro-hegemon is. Upper riparians are generally the most powerful in terms of "water control" if technologically advanced, through the construction of dams and the production of hydro-electric power (Mehta 2003; Zeitoun and Warner 2006; Ioris 2010). Although this is most generally so, the case of the Nile River proves that there are exceptions to this rule, and that riparian position is just one of the many power dynamics that determine the hydro-arrangement of the hegemon, as Egypt is both the lowest riparian and the hegemon among its neighbors (Zeitoun and Warner 2006).

A second form of power as defined by Lukes is related to who has the "control over the rules of the game." This type of power has been also coined as "bargaining power", and is analogous to Nye's (2004) concept of "soft" power. Bargaining power refers to the capacity of one state to set the agenda and define what kinds of decisions are important and what decisions are not. "... this form of power consists essentially of stripping the weaker party of the capacity to choose between compliance or non-compliance when confronted with the demands of the stronger party" (Zeitoun and Allan 2008, 7).

A third form of power identified by Lukes is called "ideational power", and refers to the capacity of a state (generally the hegemon) in re-writing the rules of the game. This is a "persuasive" form of power. It involves not only the previously mentioned "soft power," where certain items of the agenda get removed or forwarded, but the additional component of normalizing new views and knowledge, such as neoliberal views about water. This form of power is best known as "authoritative knowledge" (Goldman 2001) where the "hegemon employing this form of power has considerable ability to (re)write the rules of the game, to represent the world in a particular way - and find these representations accepted and reproduced by those not in power" 
(Zeitoun and Allan 2008, 8). In addition, hegemonic stability theory explains that not all weak states lose in the struggle over resource control. Weaker states are usually benefited from the hegemon's decisions and most often enjoy "free rides" (Zeitoun and Warner 2006, 439).

Zeitoun and Allan's (2008) analysis on hydro-hegemony and power will prove beneficial to the section on the politics of scale as this literature allows situating this knowledge through the lenses of socially-produced narratives which further re-produce the scale at which specific phenomena is taking place within a given spatio-temporal context. In other words, Misiones' discourses on power asymmetries and issues of cooperation will be treated as socially coproduced storylines that are dynamic and contentious at a given time and place, whose reproduction occurs through processes that involve social acceptance and normalization.

\section{The Politics of Scale}

The idea that the scale at which a particular phenomenon occurs is socially constructed and contingent upon stakeholders' decision-making processes at a given time and place is widely accepted among political geographers (Smith 1992; Swyngedouw 1997; Marston 2000; Brenner 2001; McCarthy 2005). Most useful to the analysis of scale for the governance of the GAS is Sallie Marston's definition of operational scale, which refers to "the level at which relevant processes operate" (Marston 2000, 220). In general, this literature reveals that scale is a problematic concept when treated as ontologically given in the form of "fixed, pre-given, or hierarchical" (Norman, Bakker and Cook 2012, 54) and that attention should be paid to the practices and processes that shape (enable or deter) a specific scale through social reproduction (Norman, Bakker and Cook 2012; Marston 2000). Brown and Purcell (2005), cited in Norman, Bakker and Cook (2012), recognize that "(1) scale is socially constructed, (2) scale is both fluid 
and fixed, and (3) scale is fundamentally a relational idea" (Norman, Bakker and Cook 2012, 54). In this sense, scale has been theorized as a social construct because it is dependent upon stakeholders' decision-making processes reflected as their spatio-temporal blueprint in the making of such scale.

Similarly, analyses on the politics of scale in water governance are useful (Norman, Bakker and Cook, 2012; Budds and Hinojosa 2012), as is the particular focus on the rescaling of water governance (Norman and Bakker 2009; Perrault 2008; Budds and Hinojosa 2012), which involves "shifting the scale at which both biophysical and socio-economic processes that mediate the connection between humans and water occur" either upwards, toward a "state-hydraulic paradigm" or downwards, through the "empowerment to local communities" (Clarke-Sather 2012, 100-101). In this sense, analyses on water governance rescaling have largely focused on identifying the level at which a particular scale is enabled through actors' decision-making processes in relation to the accessing, governing and controlling of natural resources. For example, Norman and Bakker's (2009) analysis on rescaling of the water governance processes in two areas of the Canada-U.S. border show that although increased participation has been conferred to the locals, these individuals have not been empowered in the decision-making processes. Therefore, the rescaling of water governance was not occurring at the local level.

Perrault (2008), in his analysis of water governance post-neoliberal restructuring in Cochabamba, Bolivia, describes that the analysis of rescaling is complex because neoliberalization moves from "state-centric (public-sphere)" to "market based (private-sphere) forms of governance" in which increased participation from different state and non-state actors functioning at different scales (local, national, transnational) occurs through a liberalization of trade, "particularly international trade" (Perreault 2008, 836-837). In this respect, Misiones' provincial water marketization contends to the trend that neoliberalization processes occur via the 
transition from a state-centric to a market-based sphere as the state, in this particular case, is involved in both functions. Furthermore, under neoliberal frameworks of governance, the scale of governance becomes multiplied at different levels. As Perreault remarks,

Of crucial importance to any geographical understanding of environmental governance is that these institutional frameworks [such as privatization] operate across socio-spatial scales, and may simultaneously encompass transnational firms, multilateral lending institutions, bilateral aid agencies, NGO's, state agencies, municipal governments, and local resource users' associations. Because this process involves multiple institutions operating across multiple scales, each with its own ideological perspective, management objectives, and rules of operation, there can be and often are competing systems of practice, regulation, norms, and objectives within and between those different scales"

(Perreault 2006, 153-154).

Feitelson and Fischhendler (2009) note, in relation to their analysis of transboundary water governance in Israel and its neighbors, how neoliberalization (in its many types of transformations) inserts an economic scale of governance "that is determined theoretically by market forces and within which market transactions in water can take place" (Feitelson and Fischhendler 2009, 732). And both coincide with Perrault (2006) that this scale often exceeds the limits of the national and basin scale "as it might be worthwhile to import and export water across boundaries". Feitelson and Fischhendler (2009) diagram of the "spatial organization" (Figure 1) shows some of the intervening scales in water management, including the economic scale. Furthermore, the determination of the most prominent scale of governance is generally an outcome of ideological and political struggle (Swyngedouw 2005; Perreault 2008; Feitelson and Fischhendler 2009) through which discourses and practices are fundamentally constituted (Ekers and Loftus 2008).

Two relevant questions for this study are: what scales of water governance are enabled through Misiones' discourses and practices of water governance? And what scales are left unattended, and therefore deterred? This comparison can be understood in terms of the notion that 
scale is fundamentally relational (Marston 2000; Brown and Purcell 2005) and cannot be analyzed in isolation, but needs to be treated in the context of other scales of governance. As Perrault (2008) remarks, "neoliberalization of water governance has involved forms of institutional reconfiguration that have in many cases limited the ability of most people to participate in the management of water they use on a daily basis" (Perrault 2008, 837). This illustrates how neoliberal frameworks of governance both enable particular scales to become fully active, while disabling other scales, such as the local (Budds 2004).

The analysis of Misiones's discourses on power asymmetries and cooperation therefore will be queried through these frameworks to help explain how these discourses simultaneously enable and disable certain scales of water governance, and what this rescaling speak of in relation to the sustainable governance of the GAS. 


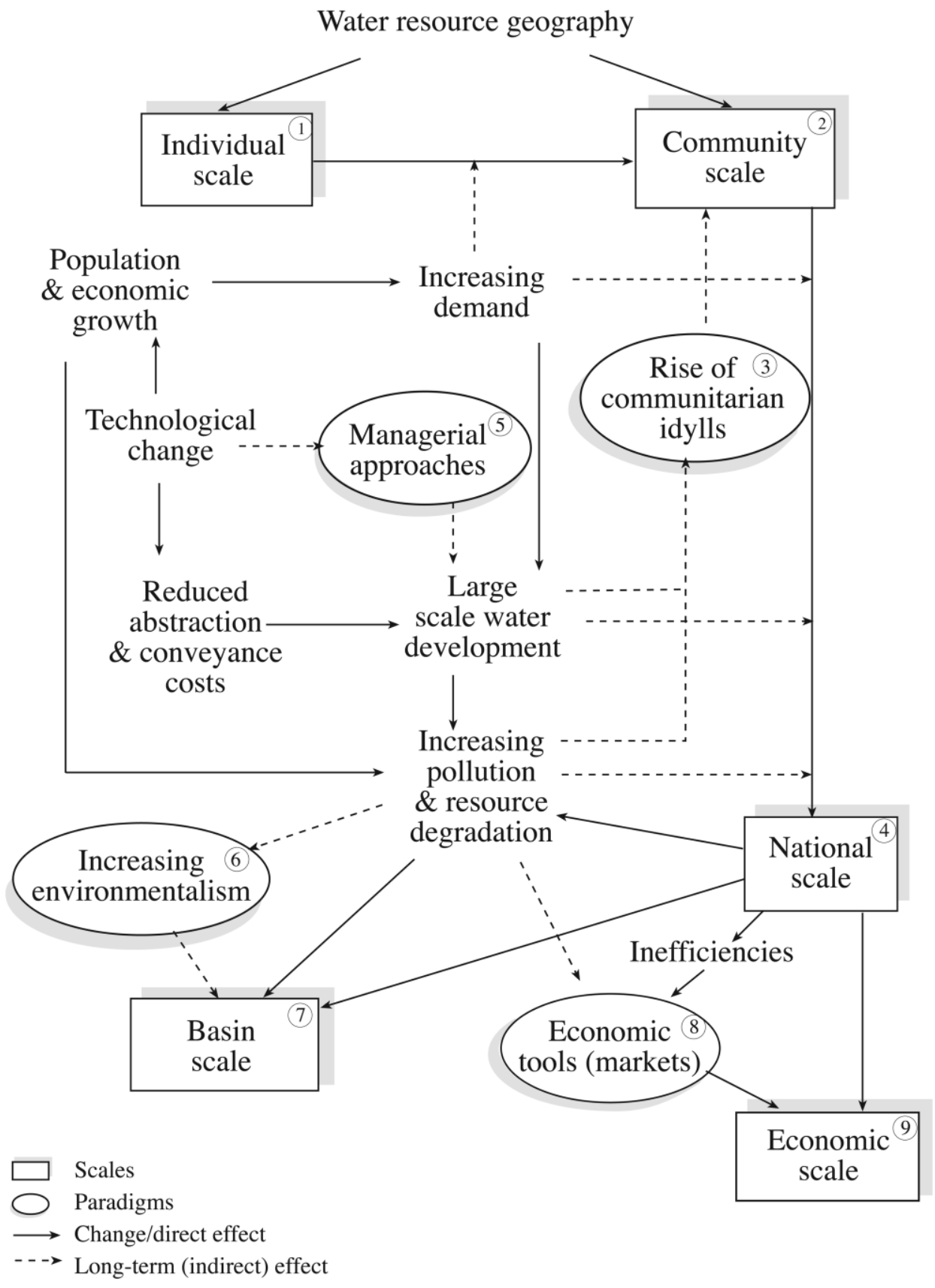

Figure 1. The spatial evolution of water management (Source: Feitelson and Fischhendler 2009). 


\section{CHAPTER III}

\section{CONTEXT}

Introduction

To situate the case of Misiones, this section provides an overview of the study area which consists on the hydrological and socio-economic characteristics of the province of Misiones, and the hydrogeology of the GAS. This chapter also renders a description of Misiones' political economy of the water sector in the context of two neoliberal instances: the de-regulation and privatization of Argentina's water sector of 1989 and the World Bank-led Proyecto para la Proteccion Ambiental y Desarrollo Sostenible del Sistema Acuifero Guarani (The Guarani Aquifer Environmental Protection and Sustainable Development Project) that took place between 2003 and 2009. Furthermore, this section offers a detailed account of Misiones' current water sector arrangement, the water reforms of 2007 and 2009, and the subsequent emergence of Aguas Misioneras Sociedad del Estado (AMSE) in 2010. Lastly, AMSE's scope of water governance is provided through a description of the two main legal instruments derived from the water reforms of 2007 and 2009, the laws No. 95 and No. 149, respectively.

\section{The Study Area}

The selected study area for this case study is the province of Misiones, Argentina. The reason for this selection has been based on the recent observed practices of water marketization at 
the state level in Misiones which contrast with the regulations delineated by Guarani Aquifer Agreement at the regional level.

The province of Misiones occupies a central south-east position with respect to the La Plata River Basin and a central position to the Parana River Basin in which the Guarani Aquifer System (GAS) is contained (Figure 2). The GAS covers an estimated surface of 1.2 million $\mathrm{km}^{2}$ between a $12^{\circ}$ and $35^{\circ}$ south latitude and a $47^{\circ}$ and $65^{\circ}$ west longitude (Kemper, Mestre and Amore 2003; Villar and Ribeiro 2011) and has an estimated freshwater volume of 40,000 $\mathrm{km}^{3}$ (World Bank 2006). Misiones is located between three main tributaries, the Parana, Uruguay and Iguazu Rivers and is one of the most bio-diverse areas in the region. Most of the province is located in the south of the Upper Parana Atlantic Forest, an endangered forest biome of 15 ecoregions which has been reduced to $7.4 \%$ from of its original size of $471,204 \mathrm{~km}^{2}$, and which extends from Serra do Mar in Brazil to the east of Paraguay and Misiones, Argentina. Within the Upper Parana Atlantic Forest, Misiones is home to a network of green corridors, which are protected areas that connect large-scale biodiversity regions through various sustainable means (Di Bitteti, Placci and Dietz 2003).

Misiones hydrological landscape is water abundant as its political boundaries limit with La Plata River Basin's two most important rivers, the Parana River on the western side and the Uruguay River on the eastern side, which have an estimated mean annual flow of approximately $17,100 \mathrm{~m}^{3} / \mathrm{s}$ and $4,300 \mathrm{~m}^{3} / \mathrm{s}$, respectively. Although Misiones has a central position to the GAS, the aquifer is highly confined (Figure 3) throughout most of the province, with deep Cretaceous basalt sheets of an average depth of $400 \mathrm{~m} \mathrm{bgl}$ (below ground level), extending to more than $1,000 \mathrm{~m} \mathrm{bgl}$ in some areas. Below the $400 \mathrm{~m}$ bgl, exploitation becomes economically unviable, unless for hydrogeothermal applications (Pochat 2011; World Bank 2009). 
The Guarani Aquifer System is composed of loosely-cemented aeolian and fluvial sandstones from the Upper Jurassic and the Lower Cretaceous periods which are overlain by basalt sheets of the Upper Cretaceous period. As its name reveals, the aquifer is a system of two major basins functionally connected by an arch and highs. As the following report states,

"The aquifer occurs in two major semi-independent structural basins - the Central Parana (which is relatively known) and the south-western Chaco-Lower Parana (whose geology and freshwater distribution is much less understood). These two basins are separated by the pronounced Asuncion-Rio Grande arch [...], and this, and other 'structural highs' (such as the Ponta Grossa in Brazil-Parana State), appear likely to affect aquifer structure generally, to control the presence of magmatic intrusions, and thus have a strong influence on the groundwater flow regime" (World Bank 2006, 1).

The total recharge of the GAS has been estimated in $45-55 \mathrm{~km}^{3}$, most of which occurs through indirect recharge in the outcropping areas of the GAS (Figure 3). Current exploitation of the GAS has been estimated in $1.04 \mathrm{~km}^{3}$ per year taking into account 2,000 deep-operating boreholes (World Bank 2009). The area overlaying the GAS serves a population of 15 million, but when large cities in the vicinity of the GAS are taking into account, this number reaches to 90 million. Brazil's groundwater exploitation accounts to $94 \%$ of the total, with Sao Paulo state using $80 \%$, mainly for domestic use. Uruguay, Paraguay and Argentina follow with a $3 \%, 2 \%$ and $1 \%$ respectively. Argentina's main sovereign provinces to the GAS are Misiones, Corrientes and Entre Rios, El Chaco, Santa Fe and Formosa (Figure 2). Except for Santa Fe, these provinces consist of what is known as the provinces of el Noreste Argentino (Northeast Argentina) or NEA. Similarly to Brazil, Argentina's federal system enables provinces to exercise their legal right to govern their natural resources and develop policy. On the contrary, Paraguay and Uruguay are unitary states, in which case the water governance is left to the national government (World Bank 2006). 


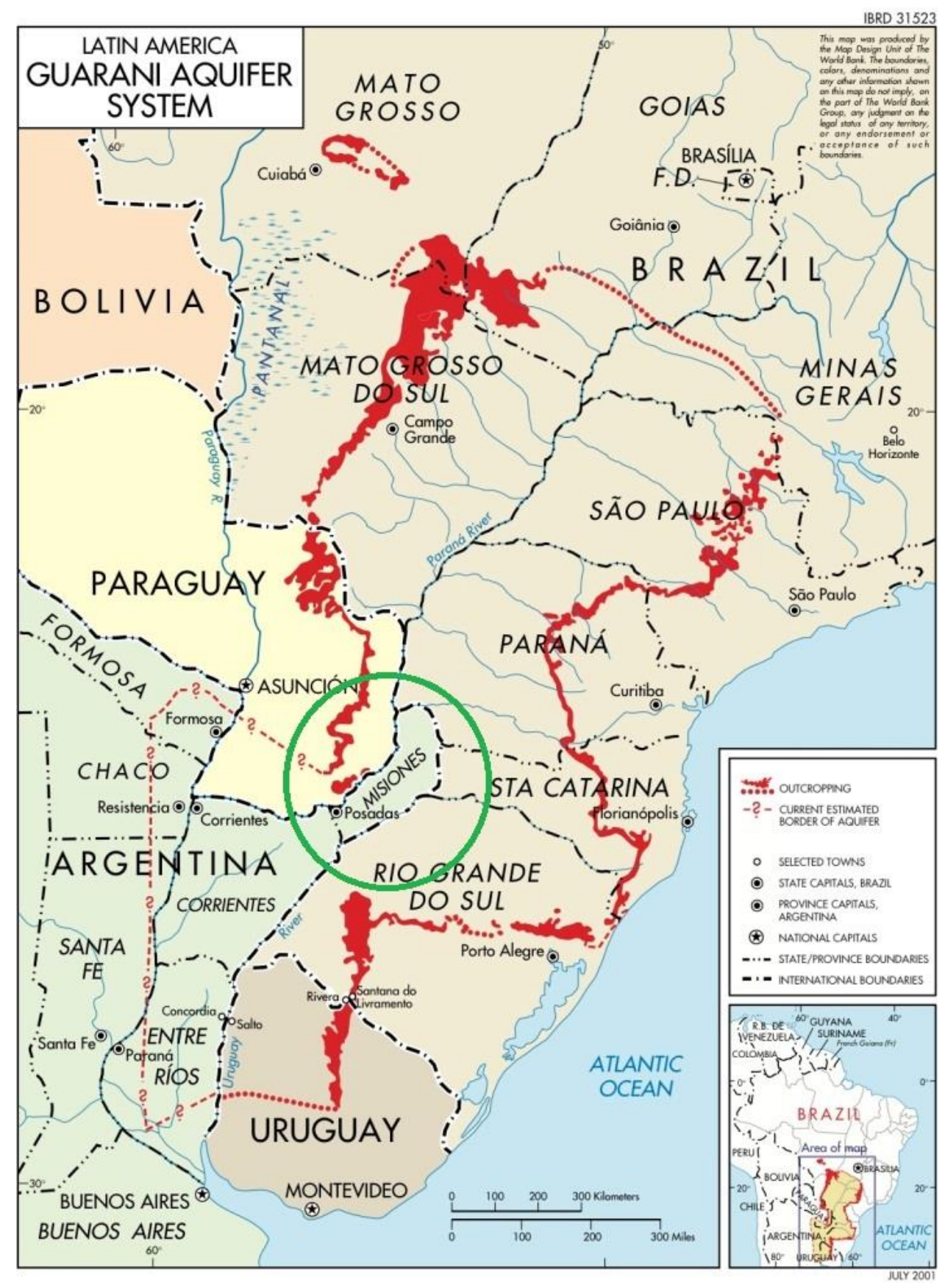

Figure 2. The Guarani Aquifer System and the province of Misiones (circled in green). (Source: Amore 2002, green circle added). 


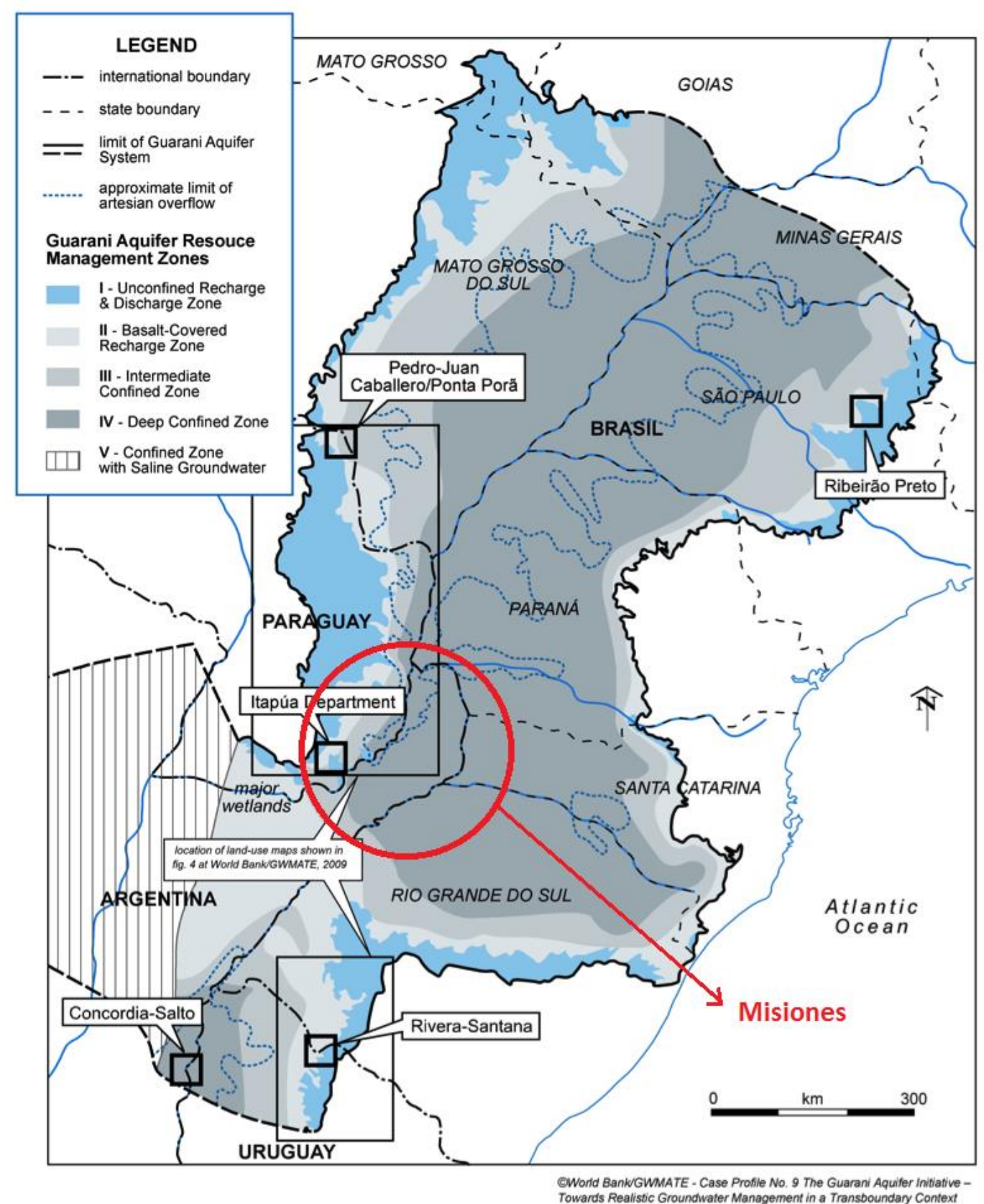

Figure 3 .The Guarani Aquifer System and the province of Misiones (circled in red). Recharge and discharge zones, level of confinement and salinity. (Source: World Bank 2009, red graphics added). 
Misiones' History and Political Economy

The province of Misiones is located in the northeast of Argentina and has a total territorial surface of $29,801 \mathrm{~km}^{2}$ and a population of 1.1 million habitants according to the 2010 census (IPEC 2014). From this amount, 70.4\% lives in rural areas (Manghi et al. 2005). The province has a history of colonization and long-lasting territorial disputes with neighboring provinces such as Paraguay and Corrientes since the period of colonization in the early 1530's. Misiones' abundant natural resources and strategic location, at the heart of the Argentinean Mesopotamia, have been at the core of many territorial and resource disputes for centuries (Gobierno de Misiones 2014).

Misiones’ Gross Domestic Product (GDP) accounts to 1.2\% of Argentina’s US\$ 475 billion 2012 GDP (World Bank 2014; Presidencia de la Nación 2012). Misiones economy is fairly diversified and relatively underdeveloped. Forestry production is primarily localized in the northwest of Misiones and in the Alto Parana region and totals 371,000 hectares of primarily Pinus (90\%) and the native Araucaria angustifolia (10\%). Deforestation of native forests has also been a central issue in Misiones' political economy, although it is currently under strict monitoring through provincial laws (albeit illicit activity continues). Other forest plantations include broadleaf trees such as Eucaliptus and Melia azedarach in the central-east and northeast of the province. The province's main agricultural crops are yerba mate, tea, tobacco, sugar cane, citrus fruits and coffee, among others (INTA 2010). In addition, livestock, tourism and local farming play a significant role in Misiones' economy. 
The Governance of the Guaraní Aquifer System

Similarly to the previously mentioned neoliberalization projects in Argentina, Latin American countries have also experienced the results of neoliberalization projects dominated by a number of transnational organizations, corporations, and lending institutions such as the World Bank (WB), the International Monetary Fund (IMF), and the United Nations Development Program - Global Environment Facility (UNDP-GEF), particularly those countries with contractual obligations with the World Bank through structural adjustments (Whiteford and Whiteford 2005).

The Guarani Aquifer System has also been subject to a neoliberalization project of development. In May 2003, the 50\% GEF-funded Proyecto para la Proteccion Ambiental y Desarrollo Sostenible del Sistema Acuifero Guarani (The Guarani Aquifer Environmental Protection and Sustainable Development Project) was launched through a loan acquired by the four Mercosur countries of Brazil, Argentina, Paraguay and Uruguay valued in \$ 26.7 million. This was accomplished under the supervision of the World Bank and the support of transnational organizations such as the Organization of American States (OAS), the International Atomic Energy Authority (IAEA), as well as through lending German corporations (World Bank 2006; World Bank 2009).

The project finalized in January 2009 after a period of political tension among the four countries and the World Bank over contractual engagements which included a privatization schedule for the GAS, and the bank's lack of data-sharing with local agencies and universities during the period of scientific assessment. During the period between 2003 and 2009, a great deal of scientific information was obtained from 4 pilot projects carried out by the World Bank: the Concordia-Salto (Argentina-Uruguay), the Itapúa (Paraguay), the Riberao Preto (Brazil) and the 
Rivera-Santana do Livramento (Uruguay-Brazil) pilot projects (World Bank 2009). Subsequently, this provided the four countries with the basic scientific knowledge to develop policy around the Guarani Aquifer (albeit the hitherto unknowns) (World Bank 2009; Lindsay-Herrera and Taks 2012).

In 2010, the four Mercosur countries adopted the United Nations International Law Commission (UNILC) 19 draft articles on the Law of Transboundary Aquifers which resulted in the Guarani Aquifer Agreement (GAA). This agreement follows both the imperatives of the UNILC draft articles and the La Plata Basin Treaty of 1969 (a treaty previously signed among the countries of Brazil, Argentina, Paraguay, Uruguay and Bolivia), which coordinated and promoted the joint development of the La Plata River Basin. The GAA ensured the four Mercosur countries with the territorial sovereignty over the GAS (Pochat 2011; Stephan 2011).

\section{Misiones’ Water Sector Neoliberalization Background}

Argentina's de-regulation of the water sector and sanitation services, as well as other resources and services (such as oil, gas, electricity, transportation and telecommunications), occurred in the late 1980's by decree through the National Administrative Reform Law No. 23,696 during the political term of Carlos Menem (Loftus and McDonald 2001). This process precipitated heterogeneous changes in the decade of the 1990's across the provinces of Argentina and their own state-regulated services. Privatization of the water sector was carried out, in most cases, in the form of a 30-year concession to international private corporations such as Suez, Vivendi and Enron (Apiazu 2007). In 1999, Misiones' state-regulated water company Administracion Provincial de Obras Sanitarias (APOS), responsible for 55\% of the water 
distribution and water sanitation services in the province and of the water enforcement activities called "la policia del agua" (which entailed maintaining the records of water wells and ensuring the access of potable water across the province) was dissolved to allow for a 30-year private concession to Servicios de Aguas de Misiones S.A. (SAMSA), a company of mainly Spanish capitals from the firm Urbaser S.A, part of the group ACS (SAMSA 2014; Interview results 2013).

At the state level, the water sector was reorganized and the original state-owned water company APOS was dissolved into the Instituto Misionero de Agua y Saneamiento (IMAS), which was left with the water provision and sanitation services of the municipalities of San Pedro and Puerto Iguazu. The privately-owned firm SAMSA in turn, received the concession of the water supply and sanitation services for the municipalities of Posadas and Garupá in the Capital of Misiones. In addition, the regulatory agency Ente Provincial Regulador de Aguas y Cloacas (EPRAC) was created to regulate the firm SAMSA; and the Ministerio de Ecologia y Recursos Naturales Renovables y Turismo (Ministry of Ecology and Renewable Natural Resources and Turism) acquired the role of "la policia del agua" and the governance of the GAS, among other responsibilities, such as native forest preservation.

The IMAS and SAMSA account for approximately $55 \%$ of the total share of water services provision in the province, with SAMSA having the largest portion of this share with approximately $45 \%$ of this total, and the IMAS with $10 \%$. The remainder $45 \%$ of the market share had been historically managed by cooperativas (cooperatives), mutuales (mutual benefit societies), vecinales (locals) and rurales (rurals) and individuales (individuals) which account for the water provision in the rest of the province (FEMICAP 2014; Interview results 2013). 
To date, there are a total of 42 registered cooperativas and 2 mutuales which supply potable water and other services such as gas and electricity in the province as well as an unrecorded number of rural, local and individual water connections. Some cooperatives supply potable water only; however, most cooperatives are mixtas (mixed), providing a wide range of services to their immediate community. Cooperatives are legally constituted with a statute by a number of shareholders; if provisioning water, these cooperatives are regulated by the Federacion Misionera de Cooperativas de Agua (FEMICAP). Mutual benefit societies or mutuales are notfor-profit entities legally constituted and funded by a number of shareholders upon the need to solve imminent societal problems. Local or vecinal water provision occurs when a number of 5 to 10 houses are connected to a single water intake or catchment system. Furthermore, rural connections generally start with provision of potable water to a rural school which in turn supplies water for the nearby houses. Although cooperatives are independent entities from the provincial government, they have increasingly become politicized spaces through which Misiones' marketized water governance is reproduced. This has occurred through the building of infrastructure and hydro-works to ensure the access of safe water 'for all' (FEMICAP 2014; Mehta 2003; Interview results 2013).

\section{Misiones' Re-regulation and Water Commodification}

During this period, the province of Misiones developed a number of laws that reaffirmed the territorial public domain over their watercourses and groundwater resources. In 2002, the Law No. 25.688 for the preservation of water and its rational use was sanctioned and promulgated. Article 4 of this law contemplates the institutionalization of sub-basins committees (interjurisdictional basins) for the most effective sustainable management of all waters in the province (Ministerio de Ecologia 2014). In 2007, the province promulgated the law No. 95 Sistema 
Acuífero Guarani y Aguas Subterráneas (Guarani Aquifer System and Groundwater) which reaffirms the article 124 of Argentina's National Constitution. This article grants Argentina's provinces with public domain rights over their territorial groundwater including GAS groundwater. Article 4 establishes the Ministry of Ecology and Renewable Natural Resources and Tourism as the organization responsible for the governance of the GAS and delimits its range and scope of activities, such as developing policy and regulations, coordinating and promoting sustainable management politics and promoting scientific research to ensure the proper action measures for the sustainable development of the GAS.

In 2010, the state-owned company Aguas Misioneras Sociedad del Estado (AMSE) was created with the aim to commercialize bottled water from the province's territorial water resources. Prior to this step, the Law No. 149 was enacted in 2009, assigning AMSE with the right of capturing, bottling, distributing and commercializing groundwater (including GAS groundwater), superficial and pluvial water from Misiones' territory for any use other than for the water supply sector. Article 10 of this law broadly specifies the company's profits allocation areas. For example, it states that $55 \%$ of the profit (up to a maximum of $60 \%$ ) would be allocated to social plans and works (no specification is given on what kinds of works) and research in relation to the reasonable and sustainable utilization of the provincial hydric system. The remainder $40 \%$ would be allocated to the Ministry of Ecology and Renewable Natural Resources and Tourism for the financing of environmental plans and projects (no specification is provided) (Gobierno de Misiones 2014; Interview results 2013).

The state-owned company AMSE has a dual function. It is a state-owned company under the provisions of the National Laws 20.705 of state-incorporated companies and a under the Law 19.550 of commercial-incorporated companies, as well as additional statutes demarcated in the Law 149. This duality refers to two distinctively contrasting aspects of the company. On one side, 
the company's capital is state-owned, and on the other side, the company functions as a corporation, just like any other water bottling company in the market. Furthermore, AMSE's profits are set to be utilized as funding for state-regulated institutions, such as the Ministry of Ecology RNR and Tourism, in the character of financing for their various activities related to the sustainable governance of freshwater in the province, although no clear allocative guidelines are provided in this law. In turn, the main institution responsible for the sustainable governance of the GAS, the Ministry of Ecology, becomes dependent upon institutionalized funds, if available, which are to be supplied by the bottling company AMSE, through its main commodity Agua de las Misiones (Figure 4). Furthermore, since its inception in 2011, and with 2 established water bottling manufacturing plants, AMSE has not yet re-distributed profits to any provincial organization; despite having reached full cost recovery and while envisioning a business expansion that involves the acquisition of 9 additional water bottling plants (interview results 2013).

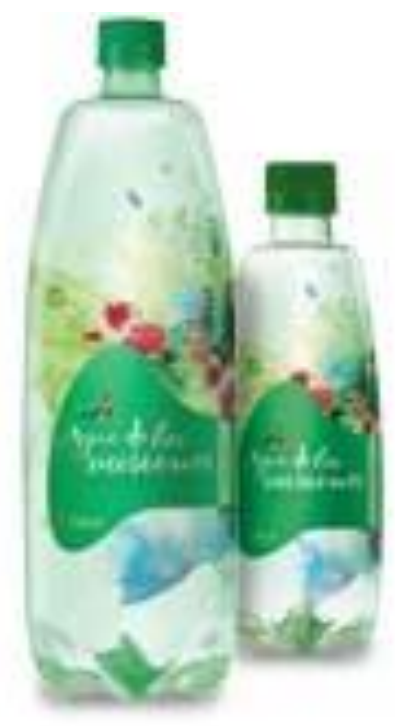

Figure 4. Agua de las Misiones (source: Aguas Misioneras 2014). 


\section{CHAPTER IV}

\section{METHODS}

"The production of knowledge in contemporary society includes what is said, what can be said, and what is silenced" (Sullivan 2001, 166).

Introduction

This study employs texts derived from archival documents, media news and interviews as the three main bodies of data. To analyze these texts, I employ discourse analysis, particularly focusing on Foucauldian (1969-1972) theory on "discursive fields" as employed by Livesey (2002) on studies of sustainable development. Similarly, I apply discourse analysis to the discursive fields of sustainable development, neoliberalization and cooperation, as spaces of contention through which knowledge is perpetually reconstituted, reproduced and contested through power relations. Through this method, I assess how narratives of water governance are socially constructed at the provincial level in Misiones, and in turn, how these fields are reshaped through new ideas, conceptualizations and ideology.

Consequently, this study employs discourse analysis to elucidate on how different ideas, conceptualizations and perceptions surrounding the purpose, use and accessibility of water are reproduced and conveyed by societal actors, namely those that have the decision-making power in the governance sphere, such as the government, the bourgeois, the private sector, non- 
governmental organizations (NGO's) and civil society. These distinctive actors, each with different goals and objectives are circumscribed by hegemonic views and "ways of doing" through sanctioned discourses and dominant ideology (Feitelson 2002; Feitelson and Fischhendler 2009).

The construction of knowledge is central to this study. However, this analysis is not limited to a fixed examination of knowledge construction. Knowledge is perpetually reproduced, seeking new contours and spaces according to the hegemonic agenda of the ruling actors (and counter-hegemonic responses) (Blatter and Ingram 2001; Livesey 2002). In fact, hegemonic discourses may vary according to the scale of examination. Similarly, when examining the case of the province of Misiones in relation to constructed narratives about water, this one needs to be examined in relation to the wider scales of governance (such as the national, the regional and the global) (Clarke-Sather 2012), which provides the contextual setting for this examination. This means that the analysis of discourse at the local level cannot be examined in isolation, but needs to be treated in the context of wider systems of knowledge at the national, international and transnational scale.

Because international water law has been delineated by broad principles of governance, this prescribed knowledge is subject to interpretation. It can be selectively deconstructed and reconstructed at the local level and adjusted to the political agenda of the ruling power (Lebel, Garden and Imamura 2005; Molle 2008; Metha 2003). Moreover, these agendas will vary according to the scale at which they are examined. 


\section{Discourse Analysis}

Discourse analysis has been widely employed in political ecology research (Peet and Watts 1996; Adger et al. 2001) and environmental studies (Blatter and Ingram 2001) to identify how ideas, concepts, processes or entities occurring within a socio-political context, help "to secure the power of an elite community" (Robbins 2004, 109). These studies range from analyses of deforestation, climate change, desertification and biodiversity (Adger et al. 2001), environmental security (Dalby 1992) to wild salmon fisheries (Sullivan 2001), to name just a few. Discourse analysis has also been employed in a variety of studies in the water sector from the angles of sustainable development (Allan 2005), privatization (Bakker 2003), scarcity (Mehta 2003), shifts in discourse (Feitelson 2002), economic efficiency and management (Allan 1999), policy narratives (Molle 2008) and droughts (Bakker 1999).

Discourse, broadly defined, is a "particular way of talking about and understanding the world (or an aspect of the world)" (Jørgensen and Phillips 2002, 3). In a more narrow sense, discourse is "an ensemble of ideas, concepts and categories through which meaning is given to social and physical phenomena, and which is produced and reproduced through an identifiable set of practices" (Hajer and Versteeg 2005, 175). Discourse analysis assumes that there is no single objective reality, that assumptions are shaped by language and that our interpretation of the world is socially constructed (Blatter and Ingram 2001). This poststructuralist view allows reality to be interpreted "through non-material (verbal and non-verbal, written and oral) practices in which interests different discourses serve" (Bakker 1999, 370). Discourse analysis not only entails a close examination of utterances and language patterns, but it also involves an analysis of what these texts may infer and represent and how they shape courses of action, practices and social norms. 
In addition to analyzing "discourse as text," I examine it as "social practice," to allow for broader analytic view of discourse. In this regard, I employ the Foucauldian perspective of discourse theory which views discourse as power itself, rather than as exertions of power through texts (Arts and Buizer 2009, 342). For Foucault (1972), discourses constitute "both identity and objects of knowledge" (Livesey 2002, 319). Foucault considers discourses to be perpetually dynamic and contested fields of power relations where "categories of reality" are "linked with the emergence of new authorities and institutions empowered to manage, rule, care for, or otherwise control social life, including medical and penal systems made possible only by social invention of madmen and deviants" (Livesey 2002; Robbins 2004, 109). Whether this field is medical, educational or governmental, each particular field is unstable, constantly being reproduced, reconstituted and redefined through power relations. As Sullivan (2001) remarks,

"For Foucault, discursive fields and their elements are structured in and through power relationships... Modern power relations, he argues, are neither centralized nor localized but permeate the social world, resonating, coalescing, and strengthening each other. Power is not a commodity or possession in modernity but an exercise, a relationship, a practice that engenders resistance as it operates" (Sullivan 2001, 166-167).

Similarly to Livesey’s (2002) analysis on Royal Dutch/Shell Group social report in relation to discourses of sustainable development, I focus on Misiones' discourses of sustainable development, neoliberalization and cooperation, as contentious discursive fields through which sociopolitical struggles take place. As Livesey describes when citing Hajer (1997), "In Foucauldian terms, sustainable development thus represents a space of dissension and sociopolitical struggle where competing discourses of economic and environmental paradigms are joined" (Livesey 2002, 316). These spaces of contention will be evaluated when analyzing discourses of water governance in the province of Misiones. Emerging narratives in the provincial 
agenda will elucidate on how practices are currently being shaped at this level, and what these may infer in the context of the transboundary groundwater governance of the GAS.

As stated before, the concept of sustainable development has been long embedded in international water law texts, particularly in the Law of Transboundary Aquifers crafted by the United Nations International Law Commission (UNILC). Similarly, the Guarani Aquifer Agreement (GAA) follows the imperatives of the sustainable development framework text. Sustainable development is a contested discursive field in itself not only because it lacks specificity, but it contains two major contradicting paradigms embedded in its two words. These paradigms have been identified as the socioeconomic paradigm, which prioritizes neoliberal principles of economic efficiency and development, and the radical environmentalism paradigm (Livesey 2002) which rests on four postulates, 1 . That locals are the best example to live in harmony with the environment, 2 . That decentralization and local governance is best for the social and environmental health, 3 . That capitalist markets lead to inevitable degradation and waste, and 4. "That technological advance, if not scientific progress itself, is inherently harmful and dehumanizing" (Lewis 1992, 3). Another discourse that permeates these two main paradigms is the technocentrist environmentalism discourse which prioritizes management and regulation and a "rational utilization of the environment" (Crush 1995, 86; Mehta 2003).

The Data

Three sources of data have been employed for the analysis of discourse in this study. These are texts derived from archival documents, media news and interviews. These three bodies of data have been carefully selected as a way to provide different views and coalescing 
knowledge with respect to one issue, and in turn, to increase the validity of the findings through methodological triangulation (Layder 1993; Yeung 1997; Gomez and Jones III 2010).

"Triangulation, in particular its methodological form, can do much to improve the validity and reliability of data collected. This contribution is based on the assumptions that the method is well understood and different data complement each other in revealing different facets of the social world" (Yeung 1997, 64).

\section{Archival texts}

The first body consists of archival texts derived from peer-reviewed journal articles, nongovernmental and governmental reports, newspaper news and legal instruments at the local, national and international level. Archival texts are an excellent source of historical data which allows building a contextual and theoretical framework specific to the problem at hand (Black 2010; Sithole 2011). Norman and Bakker (2009) for example, examine the rescaling of water governance between the U.S. and Canada, heavily relying on historical formal and informal instruments between the two countries.

In regards to legal instruments, I particularly focus on the following treaties and laws: The UNILC Draft Articles on the Law of Transboundary Aquifers (A/RES/63/124), the Guarani Aquifer Agreement derived from the former, the Article 124 of Argentina's National Constitution, and two instruments specific to Misiones' water governance, Aguas Misioneras Sociedad del Estado Law No. 149 and the Sistema Acuífero Guarani y Aguas Subterráneas (Guarani Aquifer System and Groundwater) Law No. 95. The selection of these instruments is based on their direct applicability to Misiones' groundwater governance at the international, national and local level (Table 1). 


\section{Media News}

The second body of data employed in this study consists of texts from media news obtained from uploaded videos in the internet related to Misiones' water corporation AMSE and its emerging practices of water commodification, marketization and re-regulation of water resources. These videos are a series of local news coverage to water governance officials which address the logic of this company in relation to bottling groundwater and the sustainable groundwater governance of the GAS, originally shown in local television news and subsequently uploaded in the internet by different local media television channels such as Noticias del 6 and Canal 4 Posadas. A good example of water-related discourse analysis employing media news is Haughton's (1998) analysis of Yorkshire's 1995-96 water drought, which followed Bakker's (1999) critique, based on his overreliance on media news to assess public discourse.

A total of 10 videos (of 5 minutes on average) were selected and transcribed (see Appendix D) (Potter 2004). The selection of these videos was primarily based on the total availability of videos related to this topic. A total of 15 videos were identified as relevant to the topic of analysis. From this total, 10 videos were selected as containing rich discursive patterns regarding AMSE's vision of re-regulation and groundwater governance in Misiones. The five videos that were not selected were found to contain similar discursive patterns as the ones included in the analysis. After the videos were transcribed, content analysis was devised. In addition, salient discursive patterns were identified among the videos and were classified into four main distinctive themes for further analysis. Data was subsequently categorized within the groups of sustainable development, cooperation and neoliberalization. These groups served as the basis for the identification of discourses within each topic of analysis. 
Table 1. Legal Instruments Intervening in Misiones' Water Governance

\begin{tabular}{|c|c|c|c|c|c|c|}
\hline Level & Year & Parties & Agreement & Institution & Scale & Type of Right \\
\hline International & 2010 & $\begin{array}{l}\text { Brazil, Argentina, } \\
\text { Paraguay and } \\
\text { Uruguay. }\end{array}$ & $\begin{array}{l}\text { Guarani } \\
\text { Aquifer } \\
\text { Agreement }\end{array}$ & $\begin{array}{l}\text { UN International Law } \\
\text { Commission - Law of } \\
\text { Transboundary } \\
\text { Aquifers (Resolution } \\
\text { A/63/124) }\end{array}$ & $\begin{array}{l}\text { Guarani Aquifer } \\
\text { System }\end{array}$ & Sovereign rights \\
\hline National & 1994 & $\begin{array}{l}\text { National Governemnt } \\
\text { of Argentina }\end{array}$ & $\begin{array}{l}\text { National } \\
\text { Constitution: } \\
\text { Article } 124- \\
\text { Reform of } \\
1994\end{array}$ & $\begin{array}{l}\text { Government of } \\
\text { Argentina }\end{array}$ & Provincial & Public domain rights \\
\hline Provincial & 2007 & Province of Misiones & $\begin{array}{l}\text { Law No. } 95 \\
\text { Guarani } \\
\text { Aquifer } \\
\text { System and } \\
\text { Ground Water }\end{array}$ & $\begin{array}{l}\text { Province of Misiones, } \\
\text { Argentina }\end{array}$ & $\begin{array}{l}\text { Groundwater } \\
\text { including Guarani } \\
\text { Aquifer System } \\
\text { groundwater }\end{array}$ & Public domain rights \\
\hline Provincial & 2009 & $\begin{array}{l}\text { Aguas Misioneras } \\
\text { Sociedad del Estado } \\
\text { (AMSE) }\end{array}$ & Law No. 149 & $\begin{array}{l}\text { Province of Misiones, } \\
\text { Argentina and AMSE }\end{array}$ & $\begin{array}{l}\text { Surface, pluvial } \\
\text { groundwater and } \\
\text { Guarani Aquifer } \\
\text { System } \\
\text { groundwater }\end{array}$ & $\begin{array}{l}\text { Rights of capturing, bottling, } \\
\text { distributing and } \\
\text { commercializing of all } \\
\text { territorial provincial water for } \\
\text { any use other than domestic } \\
\text { water supply }\end{array}$ \\
\hline
\end{tabular}

Source: Adapted from Pochat 2011. 
Interviews

A third body of data employed in this study consists of primary data derived from 8 semistructured interviews performed to 8 different key actors related to the groundwater governance in the province of Misiones, Argentina. Interviews have been largely employed in transboundary water analysis as a means to obtain narratives from key actors involved in water governance such as for analyses on rescaling of transboundary water governance (Norman and Bakker 2009), resource struggles under neoliberal frameworks of governance (Perreault 2006; Perreault 2008) and treaty disambiguation (Fischhendler 2008). Approval for the research methods was obtained from the Human Subjects Protection Program Office at the University of Louisville on January 22, 2013 (Appendix A). Subject identity cannot be disclosed as per confidentiality requirements. However, four distinctive groups of actors can be identified, such as 4 governmental water governance-related officials, 2 non-governmental water governance-related actors, 1 environmental sciences scholar and 1 independent environmental sciences scholar. The interviews were conducted from February 1 to April 30, 2013 via phone. Snowball sampling was employed to an initial list of 20 key actors. This consisted in contacting the key actors from the initial list and obtaining references for additional actors to interview. This process also entailed discarding potential participants that were not interested in participating in the study or were no longer active (Gomez and Jones III 2010).

A questionnaire containing a total of 30 closed and open-ended questions was administered to the participants in the Spanish language (Appendix B. See Appendix C for English version). The interviews lasted approximately ninety minutes. The questions assessed participants' knowledge about water governance practices in Misiones, particularly focusing on the periods of 2003 and 2013 to assess shifts in the water governance. The questionnaire also assessed participant's narratives about water rights, public participation, international relations 
and groundwater abstraction practices, among others. Semi-structured interviews were chosen for this study as means to collect both data systematically, in the case were pre-set categories were provided and also to allow participants to discuss issues without pre-established themes.

Open-ended questions allowed participants to provide spontaneous narratives which in turn, provided additional material for the analysis while offsetting any researcher's biases and pre-conceptualizations (Norman and Bakker 2009; Longhurst 2010). Each participant was advised about the interview procedures both verbally and in written (prior to the interview via email), which informed him/her that the interview would be recorded unless she/he would not be in agreement, in which case the researcher would take notes only. All participants provided their consent to have their interviews recorded. This allowed for an accurate transcription of texts (Potter 2004). 


\section{CHAPTER V}

\section{EMPIRICAL FINDINGS}

\section{Shifts in Misiones' Scale of Water Governance}

Archival, media news, and interviews have yielded significant information in regards to changes in Misiones' water governance during the period from 2003 to 2013. Three types of changes have been identified: organizational, regulatory and hydro-social changes. At the organizational level, Misiones' water sector has had minor restructuring. The privatization of Administracion Provincial de Obras Sanitarias (APOS) in 1999, which resulted in the creation of the Instituto Misionero de Agua y Saneamiento (IMAS) and in the 30-year concession through Services de Aguas de Misiones S.A. (SAMSA), occurred prior to the period of examination queried in this analysis. However, a significant organizational change occurred in 2010 with the simultaneous emergence of Aguas Misioneras Sociedad del Estado (AMSE) and its private library, the Centro de Documentacion de Aguas Misioneras (Center for the Documentation of Aguas Misioneras), following Misiones' water re-regulation instances of 2007 and 2009 (Aguas Misioneras 2014; Media analysis 2013). This organization change is of significant relevance to this analysis.

In addition, significant changes occurred at the regulatory level during the period from 2007 to 2009, which unveil a strong statist re-regulation of water resources in the province. These changes occurred following a period of uncertainty about the future of the GAS mobilized as “conspiracy theories" (National Geographic 2006) of future imminent water wars and invasion 
from power nations. This period also coincides with the World Bank-led Proyecto para la Proteccion Ambiental y Desarrollo Sostenible del Sistema Acuífero Guarani (The Guarani Aquifer Environmental Protection and Sustainable Development Project) which began in 2003 and ended in 2009 (World Bank 2009), and was best captured by the following interviewee,

"There was a time, when they started to talk about the Guarani Aquifer... And it was like Misiones was precisely seated on a gold mine, or on the golden eggs. And there was a strong dialog about an imminent water war and that we were laying on top of the big water bomb... It was a very strange thing... In my view, it was some people's speculation for us to start noticing, in good time, about the value of water, but it was also a speculation from a political sector that was not well informed but wanted, through legislation, to take charge of a resource that had been down there for many years, without foreseeing what was happening up here" (Interviewee 2013).

This narrative not only shows the contextual backdrop of Misiones' water governance during the period from 2005 to 2006, but it also speaks of the disconnection between the subsequent water policy reform of 2007 and the hitherto socio-economic processes occurring in the province. This disconnection also speaks of Misiones' government focus on new regulations that favored the ownership of water resources rather than enabling beneficial links between water governance and society. Rather than enabling regulatory frameworks that take into consideration socio-nature processes occurring at the provincial level, such as understanding the relationship between the pollution derived from the 3 paper mills located in the Parana River and the GAS, to develop proper protectionist frameworks for the GAS, Misiones' focus was primarily centered in dominium (ownership). Therefore, this was achieved through Misiones' re-affirmation of public domain rights over groundwater resources, (including the GAS), through the Law No. 95, enacted in 2007. In addition, the Law No. 149, passed in 2009, provided AMSE with the rights of water commodification (including abstraction, bottling and commercialization) which occurred a year before AMSE's incorporation. 
Misiones' water policy reform of 2007 involved an operational rescaling in the water governance processes, which entailed a change in the level at which decision-making processes in Misiones' water governance occurred, through the redefinition of state rights over its territorial water resources and as a result, the redefinition of the social position through the simultaneous loss of rights to the access of common property water resources. Moreover, this shift in the scale of water governance is observed as a centralization of Misiones' decision-making processes at the provincial level through the Law No. 95, which reasserts the sole ownership of Misiones' water resources. Because the scale at which processes occur cannot be examined in isolation but rather, needs to be scrutinized in relation to other scales, Misiones' centralization of decision-making processes is understood in relation to the GAA scale, at which the transboundary groundwater governance of the GAS has been delimited (Marston 2000; Clarke-Sather 2012; Brown and Purcell 2005). Furthermore, this centralization in Misiones' decision-making processes will be further examined through Misiones' discourses of water governance, which will allow to assess if this change in Misiones' scale of water governance is simultaneously deterring and/or enabling other scales of water governance, particularly in relation to the transboundary groundwater scale of governance and the local scale (through empowered public participation) (see Norman and Bakker 2009).

Lastly, significant informal changes occurred at the hydro-social level during this period, which will be analyzed through the analysis of Misiones' water governance discourses in the subsequent sections of this chapter. Here I argue that AMSE's practices of water commodification and marketization, revealed through distinctive discursive instances, introduced contentious state-commodification practices as social norm through different discursive strategies. In this regard, AMSE's practices of water commodification were primarily legitimized through a main dual market-oriented and Keynesian-welfarist discourse that incorporated 
strategic narratives that appealed to the senses of people of Misiones, such as nation-state building (through technocratic managerial narratives) (Feitelson 2002) and symbolic discourses of provincialism, nostalgia and heroism, among others (Blatter and Ingram 2001).

\section{AMSE's Dual Market-oriented and Keynesian-Welfarist Discourse}

The main storyline emerging during this period of strong statist re-regulation (20072009), observed during AMSE's campaign to legitimize the commodification of water from the province of Misiones, was a market-oriented narrative of competition and efficiency against corporative transnationals. Through this main discourse and strategy, AMSE's storylines purported foreign corporations as "evil" and as the ones responsible for the looting of other provinces' resources. This storyline was legitimized through AMSE' strategy of provincial selfvictimization from neoliberal transnationalism, portrayed as the malaise of Argentine provinces (and in Latin American countries), and responsible for the loss of provincial rights over natural resources through de-regulation frameworks. Through this strategy, AMSE's main goal to position its main product Agua de las Misiones was achieved through two instances: On the one hand, by portraying foreign corporations as the ones responsible for the pervasive looting of underdeveloped countries' resources; and on the other hand, by portraying AMSE's water bottling industry as the solution to the pervasive loss of natural resources to transnational neoliberalism. This discourse was also enhanced along narratives of state-building through provincial re-capitalization. Furthermore, through these storylines, AMSE claimed that Argentine provinces do not need to surrender to neoliberal transnationalism, as that would involve the loss of provincial dominium rights to foreign corporations; but instead, they need to reaffirm their public domain rights and engage in market-oriented businesses themselves. 
The market-oriented discourse revealed that AMSE's main objective was to position its products in the international market as well as in highly touristic places such as the Iguazu Falls in Misiones. AMSE's main goal of entering the international market was driven by highly enticing global pricing signals that would enable the most profitable product allocation, and the speculation of a future water value increase in the global market. As the following interviewees and water official state,

"It's an ideological issue... What is the difference if you drink water from a multinational or from the province? Even more so [referring to multinationals] when the benefits are left abroad... In this case, at least they [benefits] are left to the province" (Interviewee 2013).

"Because...what we want to do is to place our water in the world so that our entrepreneurship has more profit. Because the truth is that we want to succeed. Because what we want is to do works [public works]. I want the company to succeed" (Interviewee 2013).

"Today there is no international price for water... but rest assure that in 25 or 35 years there is going to be an international price for water" (Interviewee 2013).

"So, when you compete in the internal market you fight for cents of pesos. But in the global market, you fight for cents of dollars. And that is a very different thing... So our idea is to reach the world" (Interviewee 2013).

"In matters of positioning our product, we are moving along well. We are even getting orders from other provinces. From Corrientes and Entre Rios... On the other hand we are obtaining international contacts. We are working on it" (Media analysis video 4 2012).

These narratives illustrate how Misiones' current scale of water governance has shifted to an economic scale of water governance which is multi-dimensional and in turn, is embedded in global neoliberal networks of multiple scales and scopes (Perrault 2008). Furthermore, these narratives reveal that Misiones' dominant economic scale of water governance follows a strong imperative of profit making over any hydro-social related issue. Along these lines, profit-making narratives generally stand alone; they lack a defined purpose that justifies these profit making goals. The building of "works" has been one of the main discursive strategies to justify this 
profit-making discourse, which has simultaneously been identified to be vague both discursively and legally (through the law No. 149). This shows that the building of "works" and "hydroworks" (used interchangeably) by AMSE, has been another key discursive strategy to mobilize storylines that speak about reaching international markets for maximum profit (Aguas Misioneras 2014; Interview results 2013; Media analysis results 2013).

Furthermore, the market-oriented discourse was enacted via two additional distinctive strategies. The first one was a storyline that emphasized AMSE's role as not significantly different from any other transnational water bottling corporation, in the sense that it would have the same commercial and profit-oriented goals, something that should not alarm citizens as it had been done before for centuries by foreign corporations. AMSE's narrative was then followed by a differential aspect from transnational corporatism, which was based on its protective role as a state vis-à-vis Misiones' natural resources and its citizens. In this regard, AMSE's discourses implied that this new venture into provincial commodification was a "beneficial type of commodification" versus a privately-originated commodification, implied as a "disadvantageous type of commodification.” Through this implicit narrative, AMSE reasserted that this commodification was beneficial to all the people from Misiones because it granted them labor, identity and water-related provision needs. Furthermore, AMSE's justification of this provincial entrepreneurship was based on the putative promise that this commodification would provide local labor and would ensure provincial capitalization. In this sense, this narrative introduced a new conceptualization of a provincial state as being capable of having a dual function as a provider of labor via market-oriented practices (Media analysis results 2013; Interview results 2013).

Another strategy utilized to forward this market-oriented discourse was through a stateself-victimization in relation to multinationals' strong politics of competition at the provincial 
level, portrayed as aggressive and dishonest. AMSE's market-oriented discourse was primarily centered in the struggles to position its products in the local market because of the strong multinational presence and their powerful politics against competitors. AMSE's narratives depicted multinationals as practicing "abuse of dominant position" in the market, and posing several difficulties for AMSE's product Agua de las Misiones to be accepted at the retail level. As AMSE's president Jorge Galeano remarks,

"It's a big issue, which could implicate, how I mentioned earlier in a press conference, an abuse of dominant position by many multinational companies that are very strong, right? They have very aggressive monopolist politics and obviously, they are bothered by our presence... But oh well...we knew beforehand that this would occur" (Media analysis video 4 2012).

"But what I want to explain is that some people are amazed that we are not present in some places [retail presence]... well, the reason we are not in these places is not because we don't want, it's but because we can't'" (Media analysis video 4 2012).

AMSE's dual market-oriented and Keynesian-welfarist discourse was accompanied by technocratic-managerial narratives (Feitelson 2002). Through this discourse, AMSE assured citizens that the company's profits would be returned to the province in the form of public works (mainly hydro-works), labor for the locals and the possibility of potable water access for all, including the possibility of eventually providing free water services for all. Therefore, AMSE's legitimization of this re-regulation was endorsed through a dual market-oriented and Keynesianwelfarist discourse with a focus on the building of hydro-works, something that reveals great contradictions in relation to AMSE's scope of water governance which, as per its legal framework, it is only limited to the water bottling business (Media news analysis 2013; interviewee 2013). As the following texts from the media analysis reveals,

"We are creating a new industry... a clean industry... a non-contaminating industry that will provide labor. And this is very important. I would like if someone would ask any workers from the San Javier plant, how important it is for them to have an industry in their own land [original text: 'terruño']. This is important. I believe that the 
social purpose of Aguas Misioneras is completely justified" (Media analysis video 2 2012).

"So that, this is the beginning of getting into the future... and it is a project that I can assure you [all] that in some years from now we are all going to be thankful for have taken these initiatives. Because it [Agua de las Misiones] is going to be a source of income to all the Misioneros [people from Misiones]. Because the idea is that all benefits obtained from this company get returned into hydraulic works and into that dream that I mentioned once when I talked about [providing] 500 free daily liters of potable water to each family. I said, it's all good, but how do you pay that?" (Media analysis video 3 2009).

"Because...what we want to do is to place our water in the world so that our entrepreneurship has more profit. Because the truth is that we want to succeed. Because what we want is to do works [public works]. I want the company to succeed" Interviewee 2013).

A content analysis of media news also reveals that AMSE's primary goal was to work through the politics of the market to position its main products. For example, AMSE's discourses showed dominant narratives of positioning, competition and profit-making rather than narratives about how to meet social ends, sustainable development and joint cooperation for transboundary governance. AMSE's storylines of re-regulation and water bottling were funneled through market-based discourses which provided concise information about AMSE's business-oriented steps to achieve their positioning, primarily in the provincial and international market. The Keynesian-welfarist discourse was a secondary narrative integrated in the storylines as a way to legitimize the company's main objectives. Moreover, the Keynesian-welfarist discourse was presented as brief commentaries that appealed to the people from Misiones' senses by evoking the numerous ways in which they could benefit from AMSE's practices of water commodification. 


\section{AMSE's Politics of Expansion}

Media analysis shows that the market-oriented discourse was the most salient narrative among the texts examined. AMSE's discourse was primarily focused on positioning Agua de las Misiones' products both at the consumer and retail level. This discourse was significant because it specifically targeted Misiones' people by appealing to their patriotism through framing foreign corporations as the main cause of the resource enclosure observed in Argentina and Latin America during the last decades, resulting in the overexploitation of water resources and the loss of provincial public domain rights to foreign corporations. In addition, AMSE's discourse indicated the province was capable of mimicking foreign corporations' behavior of marketefficiency and profit-making with the additional bonus of ensuring local labor and the promise of free available potable water for all. In other words, AMSE's water commodification practices were mobilized through narratives that discredited global neoliberal discourses of market environmentalism, which purported the state as incapable of achieving market efficiency and as a means to achieve optimum resource governance. In turn, these narratives contradict established binaries of public versus private, which postulate that the private sector is the only organizational entity through which market efficiency can be achieved.

Media analysis, interviews and archives also indicate that AMSE's main goal is to expand both at the product and market level. In 2010, AMSE's bottle water industry was realized with the inauguration of the plant of San Javier (Figure 5). The plant has a water bottling capacity of 4,000 bottles per hour and the main products are disposable water bottles of 1.5 and 2 liters. In addition, the plant employs 22 technical workers primarily for the blown molded plastic bottles and bottling lines (Media analysis video 6 2013). In 2013, the plant of Itacaruare (Figure 5) was created to access the international demand through the production of gourmet water bottles. The Itacaruare plant is also kosher certified, which means that their processes are approved under 
Jewish tradition, which allows the firm to reach different international markets (Misiones Cuatro 2013).

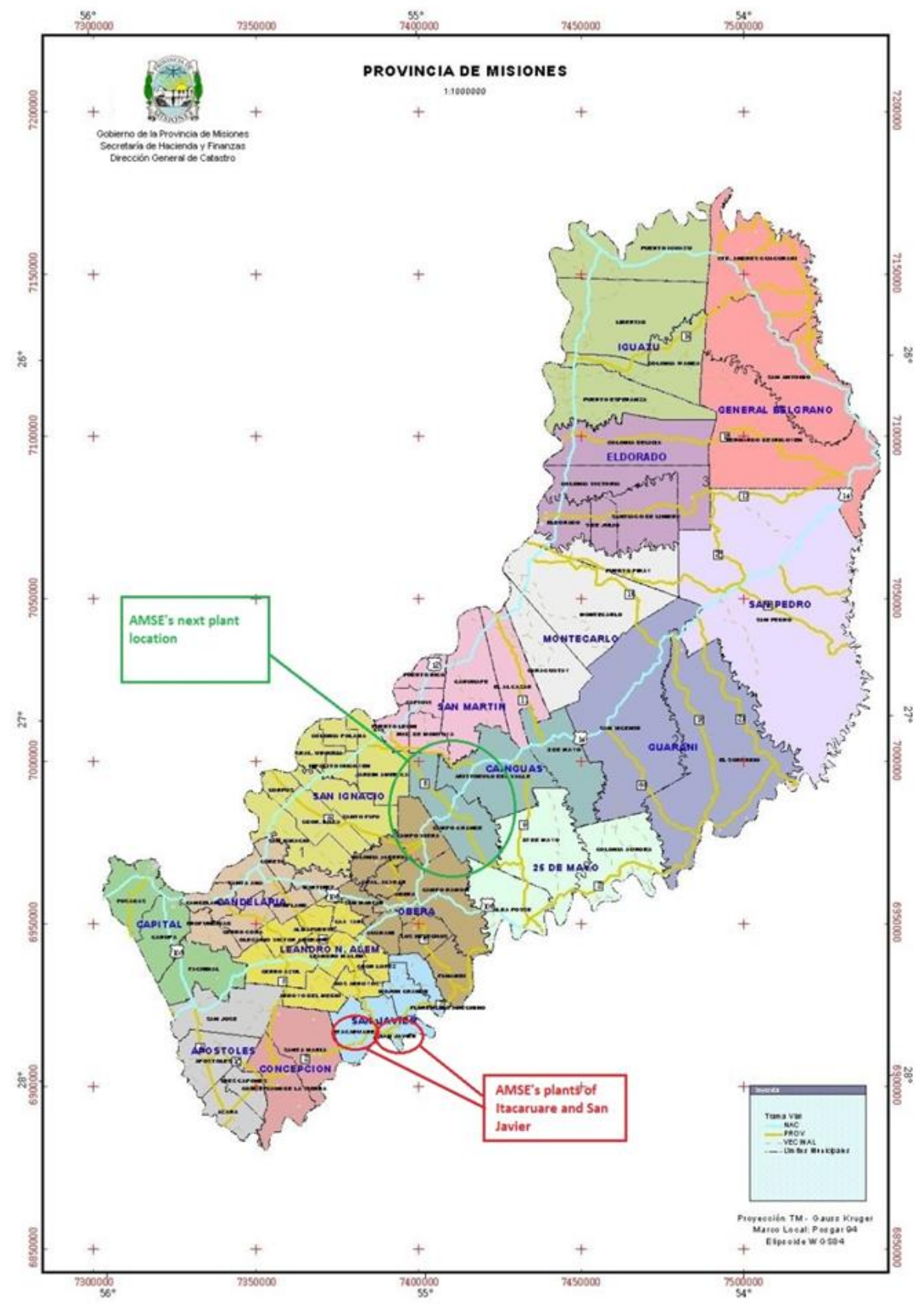

Figure 5. Political map of Misiones and its municipalities. Location of AMSE's plants of Itacaruare and San Javier (circled in red). AMSE's future plant location in the municipality of Campo Grande (circled in green). (Source: Gobierno de Misiones 2014; Misiones Cuatro 2013, green and red graphics added). 
AMSE's discourses show that the company plans to increase its market share at the provincial and national levels, while focusing on gaining participation in the international market. This last goal would be achieved by offering internationally-demanded products such as gourmet and flavored bottled water. AMSE's second plant of Itacaruare currently meets part of this demand through the production of gourmet water bottles, which are made of glass and are Kosher certified. To meet the flavored water bottle demand, AMSE plans to open a third plant in the municipality of Campo Grande (Figure 5) (Misiones Cuatro 2013). In addition, discourse analysis shows that AMSE's plans to expand its water bottling production in Misiones. This plan consists in the opening of a total of 11 water bottling plants along the pathway of 11 Jesuit Reductions in Misiones (historical remains of Jesuit settlements that date to the early 1600s), as a way to follow the path of water created in the early Seventeenth Century (Figure 6). This expansion is best captured in the following texts,

“As you know, we are following the pathway of Las Misiones [Jesuit Reductions]. And certainly, in all the places where the Jesuit and the Guarani settled there is good water. We have already studied this. And we have started. That is why the name of the plant is 'San Javier,' which was the first reduction Jesuit-Guarani. Besides that plant, we have 'Santa Maria,' where we have our second plant, and then we will continue the ring of the 11 settlements, hoping to have 11 plants" (Interviewee 2013).

"The idea is simple... that water produces water" (Media analysis video 3 2009).

The expansive nature of resource governance under a neoliberal capitalist logic can be clearly observed through these narratives. On the one side, this expansion is concrete and material, as AMSE's two plants of San Javier and Itacaruare are already in production. On the other hand this expansion is pervasive, observed through AMSE's future goals of opening new plants in different localities where previous Jesuit ruins are located. This also speaks about a resource enclosure not only of water, but to the preserved historical sites that are now under the logic of a neoliberal framework of governance, which threatens the natural preserved form of 
provincial cultural landmarks and endanger the symbolic ties of the different localities' cultural identity. Furthermore, the perpetual expansion of these processes is best captured in the sentence "the idea is simple... that water produces water." This refers to the cyclical processes in which capitalist modes of production are embedded. The idea that "water produces water" is both perpetual and cyclical and does not take into account sustainable processes of governance, but rather infers that this process will continue as long as water resources are available to reproduce this cycle once again. The more water available, the more water bottles are produced. The more water bottles produced the more capital available to reproduce this processes cyclically and as a result, endlessly.

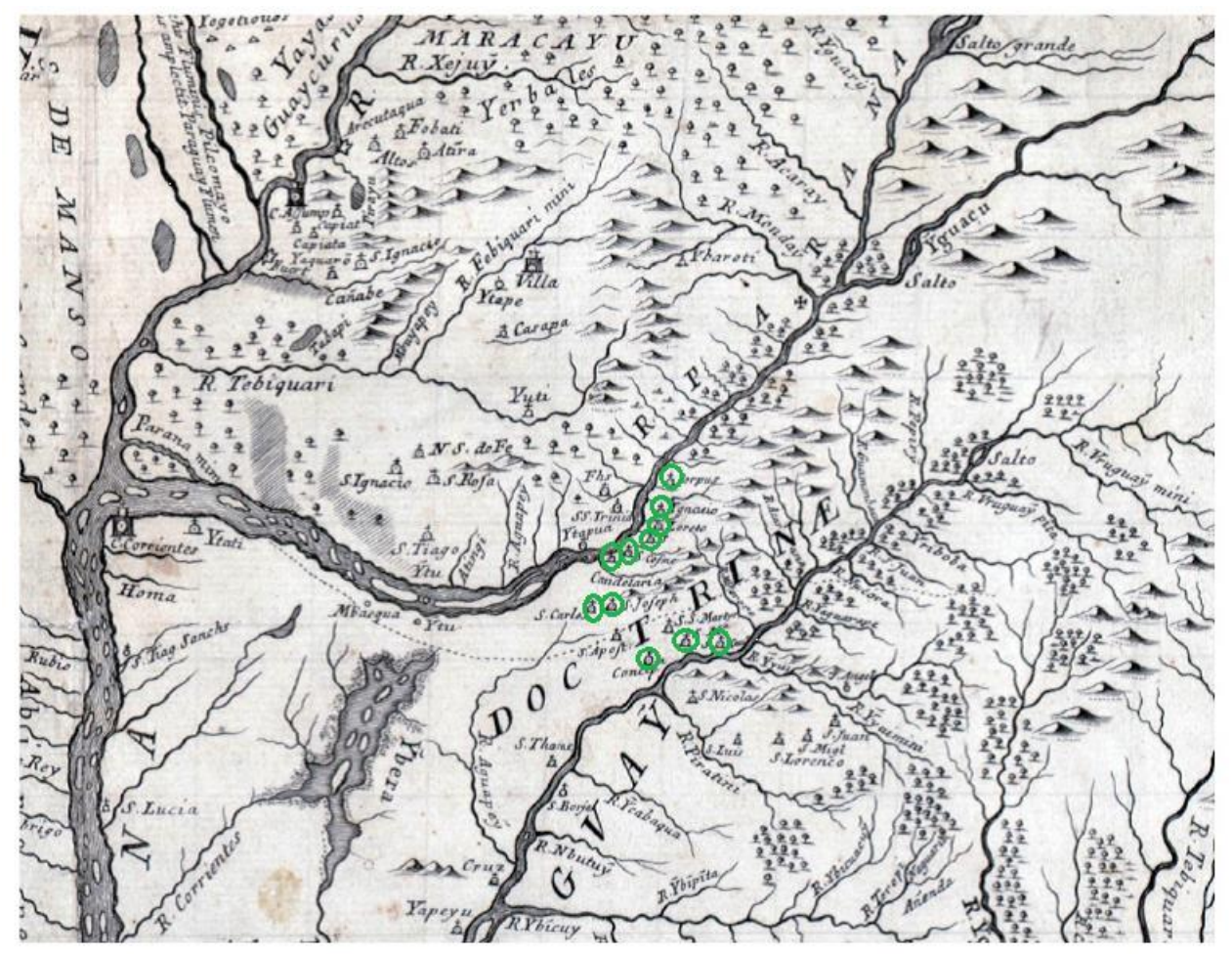

Figure 6. Enlarged section of a map of the Jesuit settlements in Misiones (and surrounding areas) in 1732 A.D. from the collection of the priest Guillermo Furlong. Jesuit settlements are circled in green (source: History Manual IPEC 2014, green circles added). 
The dual market-oriented and Keynesian-welfarist discourse was enacted through an underlying narrative of security and nation-state building (Cook and Bakker 2012; Feitelson 2002) narrative that appealed to the people of Misiones' senses in an evocative message that urged them to consider the new endeavor into statist water commodification as a necessary step to recover the territorial rights given at the national constitution level, but never claimed by the provinces. This discourse revealed a shift in Misiones' ideology, displaying a self-governing identity vis-à-vis the national, in defense of their territorial natural resources, something AMSE claimed as historic and heroic, as it had not been previously done in the country. As stated in the following texts from media news analysis and interviews,

"Well, Misiones was the 'pioneer' [original phrase: 'hizo punta de lanza']. Because I don't know if there is any other province that had such a determination to defend a resource that is "ours" [original phrase: 'que es nuestro']. In many other provinces there are big corporations that exploit [provinces'] water resources without any type of control. And what is left for these provinces? The only thing we say, is that 'something' is going to be left for Misiones" (Media analysis video 92012 ).

"It is evident that this is a matter of scale. But what I want to say and I insist in highlighting, is that we need to take into account the concept that 'we,' Los Misioneros [people from Misiones], are perusing... All across the country 'they' are beginning to understand that Misiones is the first province that had the courage to "take the bull by the horns" [original phrase: 'tomar el toro por las astas'] and instead of declaiming its rights, it's exercising them. We are taking procession of a right that is in the Constitution and has been, at times, grudgingly given to us. Misiones has taken the courage to do it and is now showing that it can be done. So...we are opening a path. We are "delineating a new direction" [original phrase: 'llenando un derrotero'] which is getting other provinces' attention” (Media analysis video 22012 ).

'Look, our idea is to defend our water because the truth is that we are the 'owners' of 'the' water and we have to impede that our resource gets taken from us [original text: 'impedir que se nos bastardee un recurso']" (Interviewee 2013).

These storylines make visible the shift in AMSE's (and the provincial government) ideology. By being the "first province" in reaffirming the public domain rights granted in Argentina's National Constitution law No. 124, Misiones demarcates a change in its political position and ideology vis-à-vis the national government and transnational neoliberalism. 
Furthermore, Misiones' reaffirmation of its public domain rights speaks of a disaffiliation from the national government of Argentina, conveyed through narratives of nation-state building and security, through messages of territorial defense such as the remarks, "to defend a resource that is ours," "we are the owners of our water," and "something is going to be left for the province."

“Botellitas de Identidad" (Little Water Bottles of Identity)

Discourses of Symbolism

AMSE's storylines were also enacted along discourses of symbolism, which appealed to the values of the people from Misiones through different strategies that reframed their perceptions around activities of water commodification. These strategies mainly appealed to patriotic provincialism, heroism and symbolic nostalgia. AMSE's market-oriented discourse of commodification was therefore forwarded through narratives which portrayed the product Agua de las Misiones as imbued with symbolic elements that would heighten citizens' pride, presence and identity. In doing so, discourses framed this product as being the identity of the province and of all Misiones' people through their labor, in the sense that Agua de las Misiones would represent them in touristic places, remember them in empty bottles cherished as souvenirs and appreciate their quality under the high standards of the international market. Such discursive patterns can be appreciated in the following text fragments,

"The only thing that we say is 'that something is going to be left for Misiones.' That labor will remain [in Misiones], than the added value that we are adding to each of these little bottles that we are producing in this precise moment [will remain]... So I ask the Misioneros [people from Misiones] that they just don't think of this [AMSE's water bottling industry] as a commercial act but that they also think that in each of these little bottles is the Misioneros' labor. And that is what I ask you [all] to think through (Media analysis video 9 2012).

"We don't ask much [when referring to attempting to place Agua de las Misiones in highly touristic places]. The only thing we ask is that they [the competition] allow our 
products to have a presence [in the market], nothing else; because they [Agua de las Misiones products] have a highly symbolic meaning in some places. Perhaps is not as profitable from a corporation's standpoint to be present in Mocona [place] at all times, but we have to be there. Why? Because it's our water" (Media analysis video 4 2009).

"It's the image of the province of Misiones. See that many tourists take the 'little bottle' as a souvenir" (Media analysis video 4 2009).

Furthermore, archival texts show that AMSE's discourses of symbolism also reframed these practices around a technocratic-managerial narrative. For example, Nancy Tognola, AMSE's Environmental and Sustainable Development Manager, states that by buying Aguas de las Misiones, "Misioneros are not just simply buying a regular product, but they are buying a product that is particularly relevant to all Misioneros because by law, this product will return $50 \%$ of its profits to hydraulic works to ensure the access of potable water to all, and $50 \%$ to improve environmental-related processes." In addition, Tognola remarks, "people that consume Agua de las Misiones are consuming sustainable development and local development" (Noticias del 6 2013). This illustrates how AMSE's discourses legitimize practices of water commodification and re-regulation around people from Misiones' livelihoods by appealing to their senses of patriotism, nostalgia as well as altruism. In this regard, AMSE's discourses have successfully introduced new practices of water bottling commodification without much contestation (only minimally contended by journalists in 2010) (Media analysis results 2013). This speaks of discourse normalization through the social acceptance of AMSE's storylines, reframed the role of the state and society vis-à-vis water resources. 
“Otros Lo Explotan Más Que Nosotros" (Others Exploit It More Than Us)

Discourses of Sustainable Development

Although discourses of sustainable development were also at the forefront of AMSE's narratives along with the dual market-oriented-Keynesian-welfarist, security, state-building, technocratic-managerial and symbolic discourses, the sustainable development discourse was identified to be brief in the texts examined. More specifically, discourses of sustainable development were remarked at the end of a specific commentary. A content analysis of media news indicates that the percentage of text in which sustainable development was discussed by the narrators was less than an average of $5 \%$ from the total texts examined (10 videos). Sustainable development narratives were not developed in depth, but appeared as rather inconsistent insertions of texts that did not necessarily followed the preceding sentences. Furthermore, these narratives would generally occur at the end of a commentary, as a way of inserting rhetorical and widely accepted environmental definitions, which in some cases, did not match the context, such as the third (video 10) of the following three examples,

"Because we want to remind everyone [added 'everyone'. Original text: 'porque recordamos'] that many transnational corporations exploit the natural resources of many provinces. For example, water. And in this case, Misiones has taken a great step in making effective its sovereignty to make a product that benefits the population for its betterment and quality of life. And these are not minor objectives. We conserve the resource when we exploit it in a sustainable way, when we use it [original text: 'aprovecharlo'] in a sustainable way, which means the resource will be utilized taking into account that future generations which will also have to have this resource available"

(Media analysis video 12012 ).

"Because until now everyone perceived it as a 'natural thing' that big multinationals would take our water and sell it. And now we are showing that the provinces, who are the owners of water, can do it on their own. So, this is a great conceptual advancement. On the other side, it allows us to exercise the unlimited defense of the resource sustainability" (Media analysis video 2 2012, emphasis added).

"We are working on positioning the product. It's slow process... We are not going to make a big fuss out of it [original text: 'no vamos a hacer alharaca']. We are not going to shout 'we are reaching the impossible.' We will continue showing that the province is 
capable of starting an entrepreneurship which will be sustainable overtime and will provide sustainability to our resources, so loved by all of us, which is water" (Media analysis video 10 2012).

These narratives are good examples of the contradictions, vagueness and broadness found within the term of sustainable development, which in these case, is observed through the fragmentally inserted texts in AMSE's discourses. A good example is the remark "the resource will be utilized taking into account that future generations will also have to have this resource available." This text fragment is identified as slightly different from the original Brundtland definition on sustainable development, as the phrase "will have to have" does not match this definition, and does not necessarily reassure that future generations will have the resource available but rather, appears as a wishful expression of this terminology, artificially inserted in the text. The second quote illustrates how texts about sustainable development can be inserted without careful thought. This quote is problematic because it basically reassures that sustainable governance can be achieved through ownership, but the term sustainability is not properly defined and is conflated with security narratives such as the statement "unlimited defense." This last statement does not describe the means as to how the sustainable development for the GAS will be achieved, but rather speaks of a security narrative that reasserts Misiones' strong position to defend this resource. The third quote shows a sustainable development text inserted after a narrative about the positioning of the product Agua de las Misiones in the market, revealing that AMSE's entrepreneurship is not currently sustainable but will be "overtime." Furthermore, none of these text insertions on sustainable development are addressed in full depth, nor do they match the contiguous text lines within the analyzed paragraphs.

Interviews and archival results indicate that the province does not currently have an updated assessment of water well perforations and other water catchment systems (different from 
water connections at the user level). This has also been aggravated by the daily illegal drilling occurring across the province which does not always follow the rigorous protective measures for proper drilling required to prevent groundwater contamination and pollution. In addition, the province has not yet identified the extent of pollution derived from 3 paper mill plants located in the Parana River. Interviewees attributed this to the belief that the Parana River's capacity is greater than any possible amount of pollution deriving from the plants, and to current knowledge of the GAS (World Bank reports) which does not recognize a hydraulic connection between surface water and GAS groundwater at Misiones (highly confined zone replenished by indirect water recharge) (World Bank 2006; World Bank 2009; Interview results 2013). Furthermore, the impact of agro-chemicals utilized in tobacco farming on groundwater has not yet been assessed, as it is considered a focalized issue in the departments of Leandro N. Alem and 25 de Mayo (Interview results 2013; INTA 2010). As the following interview remarks in relation to a lack of boreholes assessment in the province,

“Look, we don't even know how many groundwater perforations we have in the province. The Ministry of Ecology has 247 registered. I have more than 600 with the information that I gathered for my own assessment. There are many perforations for schools. We have 2,400 schools. We also have a great deal of new big hotels with the boom of tourism. They all have perforations. All the gas stations have perforations. How many are there? I don't know. There is no assessment of what you are requesting. Supposedly, it is the Ministry of Ecology who should have these records. Before the privatization [of APOS] all the responsibility fell on one entity only. It was all centralized. Now there is a great deal of disconnection with the information" (Interviewee 2013).

Results also showed that the state-owned AMSE is currently capturing water from perforations that are between 80 to 100 meters in depth. At these levels, GAS groundwater is not present in the province of Misiones, as it is considered to be found below 200 to 1000 meters depending on the area of the perforation. In addition, GAS groundwater perforations in Misiones are not economically viable, and only occur for specific purposes, such as thermal, industrial (not 
very developed in Misiones) and for domestic use in areas were potable water access has been challenging. Although the province is water abundant in general terms, mainly supplied by surface water from the Parana and Uruguay rivers, there have been some focalized water scarcity issues, particularly in high altitude in-land areas, such as in the department of Obera. Approximately half of the population from this department, which amounts to 5,000 families, has experienced acute water access stress as a result of drastically dwindling stream flows over the past four years, mainly attributed to the rapid deforestation, soil changes and climate change (Interview results 2013; Noticiero 12 2013). In this sense, although there is a significant high amount of unregistered perforations across the province, reaching the immediate groundwater table, there are only a limited number of perforations across the province reaching the GAS.

A particularly relevant sustainable development discourse that has emerged at the provincial level in Misiones can be understood in terms of an existing exploitation asymmetry deriving from the neighboring Mercosur countries, particularly from Brazil. Current knowledge on GAS exploitation levels indicates that Brazil is one of the main GAS users in a 94\%, mainly for domestic use in the State of Sao Paulo. Depth levels of the GAS are much lower in some areas of Brazil, particularly in the Sao Paulo, Mato Grosso, Mato Gross do Sul and Goias States where GAS groundwater could be found at levels of 100 meters of depth or less with relatively fractured overlaying basalt layers. Discharge areas and recharge areas are mostly present in Brazil and Paraguay, which makes exploitation fairly accessible in these countries, as well as extremely vulnerable to pollution (Figure 3) (World Bank 2009).

Brazil's high level of industrialization, economic strength and hydro-power dominated by dam control and current levels of exploitation of the GAS makes this country the hegemon in the hydroscape of the La Plata River Basin and the GAS, and among the four sovereign states of the Mercosur (Ioris 2010; World Bank 2006; World Bank 2009). This power asymmetry and the 
existing knowledge on the total level of exploitation from the GAS, estimated in $1.04 \mathrm{~km}^{3}$ (well below the recharge level of $45-55 \mathrm{~km}^{3}$ ), has enabled extensive discursive leverage for the countries of Argentina, Uruguay and Paraguay in their practices of water governance. Therefore, discourses of sustainable development are therefore minimized to an existing resource extraction asymmetry. As the following interview narratives and media analysis show,

"Well, my comment is that I am really concerned about Brazil's great level of exploitation without any type of control. Brazil, I say, is the greatest exploiter of the GAS" (Interviewee 2013).

"It's minimum [on sustainable development-oriented activities], there are no sustainable development-oriented activities performed as of today. Particularly, as I mentioned to you earlier, the fact that there is a great deal of exploitation in the recharge areas [refers to recharge areas in Brazil] where is mostly exploited and there is less control... This is an issue that worries me, because in those recharge areas there are cereal plantations like soy and, as you may know, soy requires a lot of herbicides and pesticides" (Interviewee 2013).

“The Guarani Aquifer is not being 'touched' [refers to AMSE's access to the GAS through perforations] because [the aquifer] is found at great depths [at Misiones] and it is uneconomical to extract water from the aquifer, at least in this area. On the other side, the state of Sao Paulo has some areas where the population is served from GAS groundwater. The state of Sao Paulo has an incredible amount of water wells which obtain water from the aquifer" (Media news analysis video 12012 )

AMSE's Authoritative Knowledge in Misiones' Water Governance

Both Media analysis and interviews have yielded significant information in regards to the production of new authoritative water knowledge in the province of Misiones. Three distinctive instances have been identified. First, new authoritative water knowledge has been identified to emerge during AMSE's initial stages of its incorporation. Media analysis shows that AMSE's practices of water commodification and the opening of the library Centro de Documentación de Aguas Misioneras (Center for the Documentation of Aguas Misioneras), occurred simultaneously. This center, physically situated in the same building where AMSE's offices are located, provides 
new authoritative knowledge about water, particularly in relation to AMSE's product Aguas de las Misiones. This reveals that AMSE's water commodification was strategically legitimized by forwarding new authoritative water-related knowledge through the institutionalization of an epistemic community-organization that provides selective expert knowledge on these practices.

As the following passage of a lector introducing the library reads,

"A documentation center is similar to a library, but it has the particularity that gathers, manages and defends the documentation of a specific knowledge. Aguas Misioneras Sociedad del Estado [AMSE] has the first center of documentation of the province specialized in water and environment" (Media analysis video 7 2012).

And as the following remarks from the organization's director,

"When this company [referring to AMSE], starts to circulate in the media at the beginning of 2011, one of the main objectives was to organize the first center of documentation of water and environment for the province of Misiones" (Media analysis video 7 2012).

A second instance has been identified through content analysis of media texts. These instances occurred as a series of discursive commentaries that explicitly reveal the narrators' effort in substituting pre-existing conceptualizations and notions about water for new ones. This was observed in several of the text examined, as the following examples show,

"It is evident that this is a matter of scale. But what I want to say and I insist in highlighting, is that we need to take into account the concept that 'we,' Los Misioneros [people from Misiones], are perusing... All across the country 'they' are beginning to understand that Misiones is the first province that had the courage to "take the bull by the horns" [original phrase: 'tomar el toro por las astas'] and instead of declaiming its rights, it's exercising them. We are taking procession of a right that is in the Constitution which has been many times, grudgingly given to us. Misiones has taken the courage to do it and is now showing that it can be done. So...we are opening a path. We are "delineating a new direction" [original phrase: 'Ilenando un derrotero'] which is getting other provinces' attention” (Media analysis video 2 2012).

"We said that we were going to have Aguas de las Misiones in the aisles [retail] by November, and it is. And this is... a company that is forwarding a 'basic concept' that has to do with a strategic and political conception... which is that the province claims, exercises and takes procession of a natural resource so relevant as water" (Media analysis video 10 2012). 
"It was very hard to introduce the concept that the provincial state [original phrase: ' $\mathrm{el}$ estado provincial'] had to get involved in matters of resource exploitation. It was very hard. There was a lot of resistance, particularly from journalists" (Interviewee 2013).

A third instance can be understood in terms of silenced knowledge. This type of

knowledge is generally omitted, silenced and/or obscured by the hegemonic political actors in power through a set agenda. Current practices of water governance in Misiones lacks the grounds for proper accountability as it is currently based on unknowns and monolithic data, such as information derived from the neoliberal project of sustainable development for the GAS led by the World Bank. Current provincial lack of updated and focalized scientific research about the structural and functional features of the GAS, the overreliance on broadly-produced reports for the GAS, lack of records on levels of exploitation (from the GAS and other groundwater), pollution and contamination, and lack of data-sharing among water-related organizations for the joint governance of the GAS reveals that Misiones' water groundwater governance of the GAS is primarily based on unknowns. As the following water officials' statements denote,

"That is one of my intentions... to work on that [referring to planned activity with other organizations in Misiones]. That is what I have in mind... that AMSE starts working in activities related to the water governance [referring to the GAS] in a jointly manner with other organizations. But oh well... if the others don't do it..." (Interviewee 2013).

"I think it had a partial involvement [referring to the state's involvement in the water governance around 2012] because everything that had to do with drilling exploitation and private perforations... all of that was practically chaotic. That needs to be organized. And that is what I was saying about this company [referring to AMSE] now having the monopoly. Because many people think that by having a local perforation, they can bottle water... and we want to impede that, because otherwise there is going to be an irrational and anarchic exploitation of water. Therefore, the state took the "pan by the handle" [original phrase: 'la sartén por el mango'] and I hope that AMSE helps to provide 'quality' to the matter (Interviewee 2013).

"I started to look for the information... what happens is that authorities are changed, there is no continuity... Let's say... The person that was doing this [assigned to an Ad hoc committee] from the IMAS it's no longer doing that, and the person that was in the Ministry of Ecology, who also formed part of the committee, is no longer there... If a functionary leaves, he/she is gone with all the information... What happened is that 'they' divided the province in 5 pieces and today the province has 5 or 6 entities that don't know anything [original text: 'hacen agua']. Nobody collects data, nobody pays attention to anyone, because they are all independent entities" (Interviewee 2013). 
"Well, look... the data doesn't exist... and I would be lying to you... and you know what? You won't be able to get that information because it doesn't exist... it didn't exist... and we have hopes... I talked to the people from the IMAS and other people in other areas... but the truth is that we don't have a finished assessment of water wells in Misiones" (Interviewee 2013).

These results show that not all water officials in their various positions and organizations were aware of the scale and scope of the main water-related organizations in the province. There was a high level of confusion among the interviewees as to what was the responsibility of each organization, particularly that of the Ministry of Ecology and RNR and Tourism and the IMAS. This not only affected their understanding of the responsibilities about each organization, but their own performance and integrated collaboration. For example, in trying to locate the Advising Committee (Consejo Asesor), established in the law No. 95 article 6, from other institutions for the management of the GAS, one interviewee stated,

"I started to look for the information... what happens is that authorities are changed, there is no continuity... Let's say... Then the person that was doing this in the IMAS it's no longer doing that, and the person that was in the Ministry of Ecology, who formed part of the committee, is no longer there... If a functionary leaves, he/she is gone with all the information... What happened is that they divided the province in 5 pieces and today the province has 5 or 6 entities that don't know anything [original text: 'hacen agua'], nobody collects data, nobody pays attention to anyone, because they are all independent entities" (Interviewee 2013).

Another interviewee responded, when asked about what was the role of the IMAS,

"The IMAS is the water agency of the province, the one that regulates. The EPRAC is a water authority organization for the concession and the cooperatives. But in reality, the IMAS is the one that should have the information of the records of water wells" (Interviewee 2013).

These narratives show that Misiones' main water-related entities are not fully aware of their scope and scale of activities. These results are significant as they indicate that Misiones' water governance is not organized and its processes are not occurring homogeneously across the 
water sector. For example, the IMAS is no longer the water agency of the province, as its responsibilities have been reduced following the privatization of APOS, and the EPRAC's scope is that of a comptroller authority to the concession of SAMSA. Consequently, this disorganization does not enable consistent and efficient processes of water governance that involve multiple stakeholders' decision making in issues such as the governance of the Guarani Aquifer. As a result, the uninformed and disconnected water sector of Misiones does not enable a propitious environment to develop joint planning (among organizations within the province, the national government and at the international level) for the sustainable governance of the GAS.

\section{Power Asymmetries and Cooperation Discourses}

Media analysis, interviews and archival analysis has yielded significant information in relation the level of international cooperation achieved among Misiones and the sovereign states of the GAS under the recently adopted Guarani Aquifer Agreement. Of particular interest, are the discursive formations emerging from Misiones, which reveal the current scale and scope of the GAA as well as its limitations. In addition, these discourses also speak of how sovereign rights

originating from the GAA (at the international level) intervene with the recently reaffirmed public domain rights in the province of Misiones.

A close text analysis of the Guarani Aquifer Agreement reveals that this instrument designates the countries of Brazil, Argentina, Paraguay and Uruguay as the contractual "Parties" responsible for the sustainable governance of the GAS, providing a legal framework that primarily follows the guidelines of the UNILC draft articles on the Law of Transboundary Aquifers and its embedded Brundtland definition on sustainable development. This agreement reaffirms the parties' territorial sovereignty over the GAS and establishes the basic grounds for its 
proper management, which consists on the main principles of equitable and reasonable utilization, the obligation to not cause harm, and cooperation. This last obligation involves the coordination of planned activity through a formed Commission among the four parties and the elaboration of joint regulations. The article 15 of the GAA provides that "a Commission composed of the four states party to the agreement will coordinate and cooperate amongst themselves to fulfill the principles and objectives of this Agreement. The committee will promulgate its own regulations (Villar and Ribeiro 2011, 655). Although this instrument has been signed in 2010, media and interviews analysis show that up to this date, no formal Commission has been formed to address the main principles and obligations stipulated in this treaty. As the following statements denote,

"What happens is that it doesn't exist [response to the question: how does the province establish the equitable and reasonable utilization with other sovereign states overlaying the aquifer?]. That is one of the main problems that we have in the Mercosur and in Argentina, in general... because everything is left in a nebulous. I can honestly say. There is a lot being said but little being done" (Interviewee 2013)

"On the other side, we know that Brazil has places where the population is practically served from the aquifer's water. The state of Sao Paulo has plenty of water wells and utilizes the aquifer. So that, this is an interesting field to develop cooperation between the two countries and the other countries that are overlaying the aquifer. It is a pending matter to coordinate legislations, to act in agreement and in a joint manner... to avoid, precisely, the over-exploitation" (Media analysis video 1 2012).

"I don't think there is... I think it has been left in the "forgetting files" [referring to the GAA. Original text: 'archivo de los olvidos']... the treaty.... up to date... is null"

(Interviewee 2013).

Because the GAA was singed under the term "Parties," this agreement slightly deviates from the original text of the UNILC Law on Transboundary Aquifers, which defines the contractual parts as "States." This change has proved problematic at the provincial level. Although seemingly an innocuous change, the original term "States" of the UNILC draft articles is a more inclusive term of both "States" and "Nation-States." However, the term "Party" is less flexible and can only be assigned to a specific entity. In other words, the scale of governance 
adopted in the GAA treaty, set at the national level, has revealed to be significantly problematic in federalist countries where provinces have more autonomy vis-à-vis the national. Consequently, this has posed tension with the public domain rights granted at the provincial level in Misiones. In other words, the scale of transboundary groundwater governance for the GAS, set at the national level among the four Mercosur countries, does not match with the provincial dominium rights such in Misiones' case, because the scale of governance shifts to the provincial level, but this provincial scale has not been empowered through the GAA (set at the national level).

Results show that since the treaty's inception, the province of Misiones has not been involved or integrated in the joint governance for the governance of the GAS nor at the national or international level. Interview results show that Misiones has no reach to the international level, mainly because the scale of transboundary groundwater governance has been set at the national scale, which requires provinces to go through this level in order to reach the international level. Interviewees found this task to be highly bureaucratic and ineffective, as it generally involves long steps and the involvement of the Ministerio de Relaciones Exteriores y Culto (Ministry of Foreign Affairs and Worship) before it reaches the international agenda. Moreover, these discourses depict a generalized mistrust toward Argentina's national government, viewed as lacking transparency and obscuring the joint management of GAS. As the following interviewees' reveal,

"In relation to the GAS, the nation [of Argentina]... doesn't share information with the provinces... It's some sort of 'push and pull' [original text: 'tire y afloje'] with the provinces as to 'whom' has the power of knowledge. And I am sure 'Buenos Aires' [Argentina's capital] doesn't want to share information because 'they' [politicians] want to keep the GAS governance for themselves, just as it happened with the state reregulation of hydrocarbons..." (Interviewee 2013).

"No, there is no reach [from Misiones at the international level for the governance of the GAS]. No, we don't do it...And I can even tell you that not even something at the national level has been done. Because there has been progress toward the 'San Juan' treaty [Refers to the GAA which was signed in San Juan] but if something has been done, 
it's all hidden under the desk... Nobody knows what they are talking about [on reference to the National government of Argentina]. Does it make sense? (Interviewee 2013).

"What happens is that in this game, people have to travel from Asuncion, from Brazil... it gets very complicated... When you have to turn that legislation into action it's very different. It dies on its own... More than dead... But on the other hand, you tell me... if you want to meet with someone, you need a budget, infrastructure, trained personnel and that things are fast-moving... And when they turn bureaucratic... and you have to meet in this place or that place... and when you have to deal with more urgent things than the aquifer... like solving the issue of the Dengue..." (Interviewee 2013).

"Because, let's suppose that we are dealing with something, for example, a contamination, and that has to be dealt for example, with Brazil. How are you going to go from Misiones to another country? You practically don't have any authority to talk to them. You may have a conversation perhaps from one mayor to another one in events like forums, for example, like the ones held in Uruguay.. But that is a micro thing. Then you have to take it to the governor, so that the governor takes it to Buenos Aires or the president to get connected with a Ministry so that Ministry gets in contact with the Chancellery... it's very long..." (Interviewee 2013).

In addition, interviews also signal that the role of political agency in the governance of natural resources such as groundwater does not match with the long-term planning required for their sustainable governance. This is based on water officials' storylines which indicate that political actors are not well fit for the governance of natural resources as their short political terms ( 2 to 4 years) are often detrimental to long-term strategic planning, data gathering and sharing, as they are less likely to transfer data to the following political actor. As the following interviewee states,

"There is no entity [a formed Commission for the GAS]. Let's say, I think that what is needed is a technical entity with the political support. But unfortunately all the meetings that are held are at the political level. And the politician, goes to the convention to live of the given viaticum [original text: 'a viaticar']... Does it make sense? A politician is not a person that can be involved in this type of issues. The problem with the politician is that firstly, he/she always has an immediate vision of the situation. He/she doesn't have the vision in ten years. Why? Because the politician has to survive every year with a vote, so that it has to be a rare combination... of a politician that has a technical profile, to understand the issue strategically and see it in ten years from now... What happens is that many politicians, go to those meetings and then they don't transfer the rest of the information, the know-how... They just don't transfer it" (Interviewee 2013). 
“...But they established a Commission that practically doesn't work. I would tell you that at this moment, it all depends on the states' willingness" (Interviewee 2013).

In other words, the commission responsible for the governance of the GAS, integrated by political actors that represent each country, is not currently active. According to interviewees, politicians are not individuals that should be conferred with the responsibility of governing natural resources because they are usually in term for a short period of time, and natural resources need to be strategically governed under long-term planning. Furthermore, the last quote reasserts that the commission assigned at the international level (with representatives from each country) is currently not functioning, and that provinces are not integrated in the decision-making processes for the governance of the GAS. These results further complicate the notion that the scale of the GAA does not match with the provincial public domain rights, and speaks of a generalized lack of interest to govern this resource in a proper jointly manner.

\section{Misiones' Current Politics of Water Governance}

Along with these organizational, regulatory and hydro-social changes, another informal change that has been observed is the increased level of state inherence in the governance of cooperatives. In the midst of having to resolve complex issues that require large amounts of capital expenditure for works related to the provision of potable water access and energy for their immediate communities, cooperatives have become highly politicized entities through which the province of Misiones mobilizes the construction of energy and hydro-related works (Interview results 2013). In this regard, the following interview remarks,

What worries me the most is that cooperatives are turning into markets. Cooperatives should only offer services. But I believe that when cooperatives start playing between service and profit, the ends are confused... In the majority of the cases, cooperatives 
respond to a political party. In other words, the person that ends up winning the cooperative election is usually the one that is more related to the current political party... From my point of view, this disables any real users' decision-making in concrete decisions about water" (Interviewee 2013).

In addition, the province of Misiones has been recently pointed out as one of Argentina's provinces with higher levels of corruption observed though kinship ties between the former governor and president of the House of Representatives (Camara de Diputados) Carlos Rovira and the main construction company of the province, as well as political ties with the current governor Maurice Closs (Clarin 2012). Both Maurice Closs and Carlos Rovira were at the forefront of AMSE's project initiative along with former congressman (diputado) Jorge Galeano, AMSE' current president.

In this sense, Misiones' corruption further obscures the already existing ambivalences in Misiones' water governance. These ambivalences can be observed at different levels. For example, the enforcement of activities such as "la policia del agua" has not been clearly assigned to a specific organization, but several organizations are cross-pointed as having this responsibility. In addition, the Ministry of Ecology and Renewable Natural Resources and Tourism currently lacks with funding for activities related to the governance of the GAS, such activities of control and enforcement, scientific assessment and joint planning, among others, which are informally (in vague terms) set to be supplied by AMSE's future profits through the law No. 149 (Interview results 2003; Aguas Misioneras 2014). Contradictorily, AMSE’s discourses of future expansion at the local, national and international level to provide funding for hydro-related works, do not necessarily account for activities that support the sustainable governance of the GAS. 
Lastly, interview results show that local public participation in Misiones is minimal and when occurring, it does not empower citizens. This has been particularly observed through public participation in cooperatives, where individuals rarely have a voice in the decision-making processes and are subjected to political actors who only allow participation to specific subjects. Such as the remark of the following interviewee in relation to his local cooperative,

I haven't attended a cooperative meeting in years. Because everything is so irregular these days. If you were not able to pay the last bill, then you don't get to participate. Then, the decisions are always left in the hands of a few [people] (Interviewee 2013).

This indicates that the voice of the locals, through public participation, has been disempowered from the decision-making processes in Misiones' water governance. And as a result, Misiones' local scale of water governance is currently discouraged.

\section{Limitations of the Study}

Through this case study, I assess if Misiones' practices of water governance are conducive to the sustainable governance of this resource. This study shows that the current scale for the governance of the Guarani Aquifer System, the Guarani Aquifer Agreement, is not fixed or given, but it is re-shaped and re-constructed through the individual politics of the provinces overlying the aquifer. Through the case of Misiones, this can be observed through distinctive regulatory instances, discourses and practices that reproduce a scale of water governance that does not necessarily validate the legal scale of transboundary groundwater governance adopted by the sovereign countries of the GAS.

Because case studies are limited to a relatively small scale of analysis, results may reveal rich knowledge on these specific scales and in turn, these results may speak of similar processes occurring at larger scales. However, this does not necessarily indicate that results can be applied 
to the population. In this case, the population consists of the sovereign states (from Brazil, Argentina, Paraguay and Uruguay) overlying the Guarani Aquifer System. One of the main limitations of case studies is that "the generality of the case is unknown." However, the researcher can make the decision if results may apply to the population (Clifford, French and Valentine 2010, 232). In this regard, rather than making simplistic generalizations to the population, this case study shows that although there is a legal scale for the joint governance of the Guarani Aquifer System, this scale is not reproduced as such in Misiones. In addition, because results also show that this legal scale is not active at the national and international level, these results may apply to other locales and provinces within the population. However, further case studies may enrich this analysis and add validity to this case.

Another limitation to this study is in its methods. Discourse analysis is a method that requires the researcher to deconstruct salient texts in language, in the form of discourses. Although the researcher is to be unbiased throughout the analysis, one of the critiques to this method is that complete objectivity is almost impossible to achieve because the researcher is also a subject with a particular perspective (Baker 1996). Therefore, researcher subjectivity is one of the disadvantages of this method, and therefore part of this analysis. In order to reduce researcher subjectivity in this study, I have selected various data sources such as interviews, media news and archives to provide for a triangulation of methods that anchors findings through validating checks of coalescing knowledge (Baker 1996). In sum, researcher bias has been addressed in this study by providing a multiple-method approach that allows simultaneous perspectives of similar knowledge to intervene in a particular field of examination. 


\section{CHAPTER VI}

\section{CONCLUSION}

This case of Misiones, Argentina is an example of some of the functional problems intervening in the governance of a transboundary groundwater resource, particularly through the scale of international water law. This case is relevant because it provides practical knowledge on the existing socio-economic and political complexities arising at the provincial level among sovereign states (Brazil, Argentina, Paraguay and Uruguay's provinces). These complexities are rooted in many issues that require disambiguation, and because of their hitherto level of ambiguity, they are socially constructed and co-produced through power relations among the governing entities and society. In Misiones, some of these complexities can be observed through the inconsistencies between sovereign and public domain rights at the national and provincial level in Argentina. Issues of rights can be problematic because they delimit the scale at which a particular resource is to be dispossessed, controlled and governed. By setting the governance of the Guarani Aquifer System (GAS) at the national level through sovereign rights enabled by the Guarani Aquifer Agreement (GAA), Misiones' socio-construction on this issue, assessed through the analysis of provincial discourse and practices of water governance, indicates that the province is not taking responsibility for the joint management of the GAS because the provincial scale has not been enabled through this treaty. Furthermore, by reaffirming their sole ownership over their territorial water resources (through re-regulation), this issue is further sharpened through a centralization in Misiones' decision-making processes. 
Issues of rights emerging in Misiones are relevant to this analysis because they also reveal the limitations of the United Nations International Law Commission (UNILC) Law of Transboundary Aquifers and its derived Guarani Aquifer Agreement, as well as provide significant grounds to make inferences about the limitations of this scale of governance. In addition, issues of rights in Misiones show that there are many complexities involved in the governance of transboundary groundwater resources which vary across space and time according to the individual spatio-temporal politics of sovereign states and nations. This means that each of the individual locales, provinces and nations overlying the aquifer have distinctive dynamic socio-economic and political constraints that may pose too complex to integrate under the logic of international water law. Furthermore, this study reveals that the GAA is currently not functioning under the national scale at which it has been delimited, and that the nation of Argentina has not promoted provincial integration in the decision-making processes for the governance of the GAS. Consequently, this has enabled heterogeneous responses across provinces, and in Misiones, this was realized through a centralization of decision-making processes via water policy reform and changes in provincial ideology.

This study also shows how Misiones' processes of water commodification have been mobilized through distinctive regulatory instances, new neoliberal authoritative knowledge and simultaneous discourses, legitimized through various, often polarized narratives and discourses of water governance. Misiones' water commodification can be understood as a second wave of neoliberalism, as a response to previous extralocal hegemonic neoliberal projects of governance encompassed in the GAS and in the province, such as the Proyecto para la Proteccion Ambiental y Desarrollo Sostenible del Sistema Acuífero Guarani (The Guarani Aquifer Environmental Protection and Sustainable Development Project) from 2003 to 2009, and the privatization of Misiones' Administracion Provincial de Obras Sanitarias (APOS) in 1999. Furthermore, Aguas 
Misioneras Sociedad del Estado's (AMSE) water bottling industry is a distinct case of neoliberalization because its water commodification does not entail the typical privatizationcommodification pathway within the water supply sector (i.e. through universal metering), but occurs as an outside source of funding to maintain the water supply processes through infrastructure (hydro-works), as well as to support environmentally-related plans (albeit illdetailed in the law No. 149). In addition, this neoliberalization process contradicts the wellestablished binary in analyses of neoliberalization in the water sector, in which the private and public sectors are defined as distinctively different from one another primarily through the claim that the private sector is efficient and the public sector is inefficient. Whereas the private sector is purported as efficient and profit-making oriented, the Keynesian-Welfarist state is purported as inefficient and concerned about ensuring labor and hydro-infrastructure through state subsidies. The case of Misiones shows that neoliberalization does not necessarily require the private sector as a medium for this process to take place, but it can work its way through other forms of governance, such as the public sector. AMSE's duality as both a corporation and the state proves that neoliberalization can transgress any scale or form of governance through new scripting mechanisms and regimes of truth adapted to the local idiosyncrasy and culture.

Misiones' discourses of water governance reveal a number of strategies that were employed by AMSE to legitimize its practices of water bottling commodification. These strategies have been identified as multiple practices and discursive instances imbued in many hydro-social processes to ensure the dispossession and accumulation of groundwater resources. By re-regulating its water resources, Misiones ensures the long-term dispossession and accumulation of its territorial freshwater. By transferring use rights to AMSE to enable a water bottling industry, this dispossession is incorporated in a capitalist logic of progressive production resulting in geographically expansive processes embedded in multi-scalar processes that often 
exceed the national and international scale. This can be clearly observed as AMSE's primary objective is to expand at the international level as a means to allocate its products at the maximum commodity value. Therefore, this economic scale of governance, embedded in transnational neoliberal networks of governance, is prioritized over the legal transboundary groundwater scale, the Guarani Aquifer Agreement. Furthermore, AMSE's current expansion at the provincial level indicates that these processes are dynamic and rapidly progressing to meet the increasing international bottled water demand.

Misiones' case allows identifying how water commodification processes are inserted in society through neoliberal strategies of accumulation, such as re-regulation, discourses of authoritative knowledge and symbology, normalized as necessary processes to ensure waterrelated processes in the water sector and in the wider scale of water governance in the province. The insertion of market dynamics (through AMSE's water commodification) to support Misiones' water governance processes reveals a marketization of Misiones' water sector and governance which primarily prioritizes international pricing signals over sustainable processes of transboundary governance. In addition, this accumulation strategy not only occurs through the dispossession of water resources, but also through the dispossession of Misiones citizens' labor, identity and culture. AMSE's discourses of symbology are successful strategies that redefine people of Misiones' position vis-à-vis water resources as new kinds of subjects, through the embedding of their sense of identity and livelihood in AMSE's water commodification processes.

Misiones' lack of reliable water well records and enforcement of increasing water well drilling, as well as AMSE's rhetorical and incomplete discourses of sustainable development show that practices of marketization are occurring within an unsustainable framework of water governance. Although Misiones' current levels of groundwater exploitation can be estimated to be low at the present time, various unknowns regarding increasing groundwater abstracting 
practices and pollution indicate that these processes are occurring without proper planning for the preservation of transboundary groundwater resources. These unknowns in Misiones' practices of water governance and the province's lack of cooperation with the national and international governments (for the governance of the GAS) indicates that Misiones' governance is operating under an unsustainable framework of water governance, which could pose harmful to other localities, states and nations. In addition, lack of provincial scientific hydrogeological assessments of the GAS in Misiones, as well as lack of records of existing water wells and environmental assessments that estimate the pollution (and other environmental issues) derived from Misiones' paper mills, tobacco farming and soil degradation (resulting from deforestation practices), provide favorable grounds for neoliberalization processes to occur and prevail.

This means that special attention should be placed on how this lack of knowledge enables propitious spaces for neoliberalization processes to take place, as unknowns disable enforcement and accountability processes, particularly when related to the governance of highly politicized natural resources. This also speaks on the limitations of Misiones' political actors in governing natural resources such as groundwater, partly because they cannot (or do not) ensure the transferring of knowledge, and partly because lack of information may result in being beneficial to them, in the sense that it does not require them to be held accountable for their decisionmaking outcomes.

Despite the level of ambiguity in the main principles of the UNILC Law of Transboundary Aquifers, minimum grounds in these principles have been identified as accountable in the second chapter. These minimum grounds have been postulated as the principle of equitable and reasonable utilization being relational and dependent on the principle of cooperation through data exchange among sovereign states. This study shows that cooperation among sovereign states and Misiones, for the governance of the GAS, is not occurring. 
Subsequently, because cooperation in the sense defined by the UNILC Law of Transboundary Aquifers and GAA is currently not taking place, the principle of equitable and reasonable utilization cannot be estimated, as Misiones' quantitative and qualitative indicators related to the GAS have not been identified to be exchanged with other sovereign states. Furthermore, because equitable and reasonable have not been identified, the principle of the obligation not to cause harm to other states involved cannot be measured. As a result, the basic grounds through which the main principles of the GAA operate are currently not being enabled through Misiones's water governance. Moreover, these unknowns in Misiones' water governance show that any extractive process occurring in Misiones should be considered harmful and inequitable at the present time.

According to two World Bank reports (2006; 2009), groundwater abstraction practices overlying the GAS have been identified as asymmetric among sovereign states, as Brazil utilizes $94 \%$ of the total GAS groundwater use $\left(1.04 \mathrm{~km}^{3}\right)$ for domestic use, mainly to supply potable water in the state of Sao Paulo. The remaining 6\% is utilized among Argentina, Paraguay and Uruguay. However, this perceived asymmetry is not taking into account the end use of this groundwater. For example, Brazil utilizes this groundwater mainly for domestic use, something that is contemplated in the UNILC Law of Transboundary Aquifers (5.1. and 5.2., discussed in Chapter II), which specifically delineate that states should examine other alternatives (such as surface water), prior to utilizing groundwater. Only when other alternatives are not available should states utilize transboundary groundwater to meet human needs (domestic use). However, AMSE's discourse of resource extraction asymmetry between Brazil and Argentina is mainly based on volume, not on end use.

This power asymmetry narrative has been at the center of AMSE's discourses, and has ensured AMSE a "free ride" on extractive practices without the need to meet the UNILC Law of Transboundary Aquifer principles as, according to World Bank reports, there is sufficient leeway 
for Argentina (and Misiones) to reach “equitable and reasonable” utilization (to meet Brazil's volume of groundwater extraction). In this respect, according to Misiones' discourse, cooperation among sovereign states is not occurring because of this given resource extraction asymmetry, which provides sufficient freedom to Argentina, Paraguay and Uruguay to abstract groundwater without having to provide for scientific analyses and environmental assessments locally. Furthermore, according to Misiones' discourse, cooperation among other sovereign states is not possible for Misiones because the national scale at which the GAA was agreed upon does not require provincial input in the decision-making processes regarding the GAS.

In sum, the case of Misiones shows how neoliberalization can be enacted through different forms of governance, not necessarily requiring the private sector as a medium for these processes to occur. Different accumulation strategies, such as dispossessing nature and social processes through re-regulation, commodification and new authoritative knowledge redefine hydro-social positions in the sense that they delimit how water should be treated and allocated. In turn, the redefinition of Misiones' hydro-social position materializes into practices that reveal ongoing resource enclosure through perpetual dispossession of water resources seeking best allocative markets and the best bidders for this commodity exchange, where price and profit are the main drivers for this allocation. Because these markets are primarily international, Misiones' economic scale of water governance is therefore multi-scalar. In other words, this economic scale becomes active through multiple transnational networks and corporations that are receptive to this commodity exchange, becoming the best buyers in this allocation process. As a result, Misiones' rescaling of its water governance is therefore primarily economic and embedded in multi-scalar networks of neoliberal governance.

In addition, Misiones' local scale is currently not empowered in Misiones' decisionmaking processes, particularly because cooperatives have become highly politicized institutions. 
This indicates that Misiones' water governance is highly centralized and that the provincial government has high control over its water resources and related process of governance.

Furthermore, Misiones' water marketization is occurring within an inactive transboundary groundwater scale of governance, where none of the sovereign states are actively engaged in the governance of the GAS. As a result, Misiones' lack of adherence to the legal scale of the GAA reveals that its primarily economic and multi-scaled water governance processes are occurring without a sustainable protective framework for the long-term preservation of the Guarani Aquifer System. 


\section{REFERENCES}

Adger, W.N., Benjaminsen, T.A., Brown, K. and H. Svarstad. 2001. Advancing a political ecology of global environmental discourses. Development and Change 32: 681-715.

Aguas Misioneras. 2014. Aguas Misioneras Sociedad del Estado S.A. Available at http://www.aguasmisioneras.com (last access 8 January 2011).

Allan, J. A. 2005. Water in the environment. Socio-economic development discourse: Sustainability, changing paradigms and policy responses in a global system. Government and Opposition 40(2): 181-199.

Allan, J.A. 2009. The Nile basin asymmetries: A closed fresh water resource, soil water potential, the political economy and the Nile transboundary hydro-politics. The Nile Monographiae Biologicae 89: 749-770. Netherlands: Springer.

Allan, T. 1999. Productive efficiency and allocative efficiency: why better water management may not solve the problem. Agricultural Water Management 40(1): 71-75.

Amore, L. 2002. Projeto Acuifero Guarani. A experiencia das Nacoes emvolvidas com enfase no Brasil. II Simposio Paraguayo de Geologia y III Simposio Paraguayo de Aguas Subterranea y Perforacion de Pozos. Asuncion, Paraguay.

Apiazu, D. 2007. La privatización de los servicios de agua potable y saneamiento. Las enseñanzas del caso argentino. Revista Reflexiones 86(2): 105-115.

Arts, B. and M. Buizer. 2009. Forests, discourses, institutions. A discursive-institutional analysis of global forest governance. Forest Policy and Economics 11: 340-347.

Baker, P. 2006. Using corpora in discourse analysis. London: Continuum.

Bakker, K. 1999. Deconstructing discourses of drought. Transactions of the Institute of American Geographers 24(3): 367-372.

Bakker, K. 2003. A political ecology of water privatization. Studies in Political Economy 70: 3558.

Bakker, K. 2005. Neoliberalizing nature? Market environmentalism in water supply in England and Whales. Annals of the Association of American Geographers 95(3): 542-565.

Bakker, K. 2007. The "commons" versus the "commodity": Alter-globalization, anti-privatization and the human right to water in the global south. Antipode 39(3): 430-455. 
Bakker, K. 2010. The limits of 'neoliberal natures': Debating green neoliberalism. Progress in Human Geography 34(6): 715-735.

Bakker, K. 2013. Neoliberal versus postneoliberal water: Geographies of privatization and resistance. Annals of the Association of American Geographers 103(2): 253-260.

Black, I.S. 2010. Analyzing historical and archival sources. In Key Methods in Geography, eds. Clifford, N., French S. and G. Valentine, 466-484. Thousand Oaks, CA: SAGE Publications Inc.

Blatter, J., and H. Ingram, eds. 2001. Reflections on water. New approaches to transboundary conflicts and cooperation. London, England: The MIT Press.

Braun, B. 2006. Environmental issues: global natures and the space of assemblage. Progress in Human Geography 30(5): 644-654.

Brenner, N. 2001. The limits to scale? Methodological reflections on scalar structuration. Progress in Human Geography 25(4): 591-614.

Bridge, G. 2002. Grounding globalization: The prospects and perils of linking economic processes of globalization to environmental outcomes. Economic Geography 78(3): 361386.

Brooks, D.B., and J. Linton. 2011. Governance of transboundary aquifers: balancing efficiency, equity and sustainability. International Journal of Water Resources Development 27(3): 431-462.

Brown, J.C. and M. Purcell. 2005. There's nothing inherent about scale: political ecology, the local trap, and the politics of development in the Brazilian Amazon. Geoforum 36: 607624.

Budds, J. 2004. Power, nature and neoliberalism: The political ecology of water in Chile. Singapore Journal of Tropical Geography 25(3): 322-342.

Budds, J., and L. Hinojosa. 2012. Restructuring and rescaling water governance in mining contexts: The co-production of waterscapes in Peru. Water Alternatives 5(1): 119-137.

Campana, M.E. 2005. Foreword: transboundary ground water. Ground Water 43(5): 646650.

Castree, N. 2003. Commodifying what nature? Progress in Human Geography 27(3): 273-297.

Clarin. 2012. Lanata mostro la corrupción y la desigualdad en Misiones. Available at http://www.clarin.com/politica/Lanata-mostro-corrupcion-desigualdadMisiones_0_800919954.html (last access 21 January 2014).

Clarke-Sather, A. 2012. State development and the rescaling of agricultural hydrosocial governance in semi-arid northwest China. Water Alternatives 5(1): 98-118. 
Clifford, N., French, S. and G. Valentine. 2010. Key methods in geography. Thousand Oaks, CA: SAGE Publications Inc.

Clini, C. Musu, I. and M.L. Gullino. 2008. Sustainable development and environmental management. Experiences and case studies. Dordrecht, Netherlands: Springer.

Conca, K. 2006. Governing water. Contentious transnational politics and global institution building. Cambridge, MA: MIT Press.

Cook, C. and K. Bakker. 2012. Water security: debating an emerging paradigm. Global Environmental Change 22: 94-102.

Crush, J. 1995. Power of Development. New York, NY: Routledge.

Dalby, S. 1992. Security, modernity, ecology: the dilemmas of post-cold war security discourse. Alternatives 17(1): 95-134.

Daoudy, M. 2009. Asymmetric power: Negotiating water in the Euphrates and Tigris. International Negotiation 14: 359-389.

Dellapenna, J.W. 2001. The customary international law of transboundary fresh water. International Journal Global Environmental Issues 1 Nos 3/4.

Dellapenna, J.W. 2011. The customary law applicable to internationally shared groundwater. Water International 36(5): 584-594.

Dellapenna, J.W. and Gupta, J. 2008. The evolution of the law and politics of water. Villanova, PA: Springer.

De Rosa, D. 2011. Régimen legal de aguas subterráneas. Un aproximación a la problemática del Acuífero Guaraní. Facultad de Cs. Jurídicas y Sociales. Anales 41: 74-85.

Di Bitteti, M.S., Placci, G. and L.A. Dietz. 2003. A Biodiversity Vision for the Upper Parana Atlantic Forest Ecoregion: Designing a Biodiversity Conservation Landscape and Setting Priorities for Conservation Action. Washington, D.C.: World Wildlife Fund.

Dinar, S. 2009. Power asymmetry and negotiations in international river basins. International Negotiation 14: 329-360.

Eckstein, G. 2009. Water scarcity, conflict, and security in a climate change world: Challenges and opportunities for international law and policy. Wisconsin International Law Journal 27(3): 409-461.

Eckstein, G. 2012. Commentary on the U.N. International Law Commission's Draft Articles on the Law of Transboundary Aquifers. Colorado Journal of International Environmental Law and Policy 18(3): 537-610. 
Eckstein, Y., and G. Eckstein. 2005. Transboundary aquifers: Conceptual models for development of international law. Groundwater 43(5): 679-690.

Ekers, M., and A. Loftus. 2008. The power of water. Developing dialogues between Foucault and Gramsci. Environmental and Planning D: Society and Space 26(4): 698-718.

EPA (Environmental Protection Agency). 2013. Groundwater Contamination. Available at: http://www.epa.gov/superfund/students/wastsite/grndwatr.htm (last access 23 January 2013).

Feitelson, E. 2002. Implications of shifts in the Israeli water discourse for Israeli-Palestinian water negotiations. Political Geography 21: 293-318.

Feitelson, E., and I. Fischhendler. 2009. Spaces of water governance: The case of Israel and its neighbors. Annals of the Association of American Geographers 99(4): 728-745.

FEMICAP (Federación Misionera de Cooperativas de Agua Potable). 2014. Available at: http://femicap.org.ar/contacto.php (last access 24 March 2014).

Fischhendler, I. 2008. Ambiguity in transboundary environmental dispute resolution: the IsraeliJordanian Water Agreement. Journal of Peace Research 45(1): 91-110.

Foster, S., Garduno, H., Evans, R., Olson, D., Tian, Y., Zhang, W., and Z. Han. 2004. Quaternary aquifer of the North China Plain - assessing and achieving groundwater resource sustainability. Hydrogeology Journal 12: 81-93.

Foucault, M. 1972. The archeology of knowledge and the discourse of language. New York: Pantheon Books.

Furlong, K. 2006. Hidden theories, troubled waters: international relations, the 'territorial trap', and the Southern African Development Community's transboundary waters. Political Geography 25(4): 438-458.

Glassman, J. 2006. Primitive accumulation, accumulation by dispossession, accumulation by 'extra-economic' means. Progress in Human Geography 30(5): 608-625.

Gleick, P.H. 1998. Water in crisis: Paths to sustainable water use. Ecological Applications 8(3): 571-579.

Gobierno de Misiones. 2014. Available at http://www.misiones.gov.ar/index.php (last access 7 January 2014).

Goldman, M. 2001. The birth of a discipline. Producing authoritative green knowledge, World Bank-style. Ethnography 2(2): 191-217.

Goldman, M. 2007. How water "for all!" policy became hegemonic: The power of the World Bank and its transnational policy networks. Geoforum 38(5): 786-800. 
Gomez, B., and J.P. Jones III, eds. 2010. Research Methods in Geography. West Sussex, UK: Blackwell Publishing Ltd.

Gramsci, A. 1975 [1891-1937]. Prison Notebooks. Volume 1. New York: Columbia University Press.

Greenberg J.B., and T.K Park. 1994. Political Ecology. Journal of Political Ecology 1: 1-12.

Hajer, M. 1997. The politics of environmental discourse: Ecological modernization and the policy process. Oxford, UK: Clarendon.

Hajer, M. and W. Versteeg. 2005. A decade of discourse analysis of environmental politics: achievements, challenges, perspectives. Journal of Environmental Policy \& Planning 7(3): $175-184$.

Hardin, G. 1968. The tragedy of the commons. Science 162: 1243-1248

Harvey, D. 1975. The geography of capitalist accumulation: a reconstruction of the Marxian theory. Antipode 7(2): 9-21.

Harvey, D. 2003: The new imperialism. Oxford: Oxford University Press.

Haughton, G. 1998. Private profits - public drought: The creation of a crisis in water management in water management for West Yorkshire. Transactions of the Institute of British Geographers 23(4): 419:433.

Hestermeyer H. P.; König D.; Matz-Lück N.; Röben V.; Seibert-Fohr A.; Stoll P.; and S. Vöneky. 2012.eds. Coexistence, cooperation and solidarity (Volume I and II). Danvers, MA: Martinus Nijhoff Publishers.

Heynen, N., and P. Robbins. 2005. The neoliberalization of nature: Governance, privatization, enclosure and valuation. Capitalism, Nature, Socialism 16(1): 5-8

INTA (Instituto Nacional de Tecnología Agropecuaria). 2010. Anuario Estadístico Cambio Rural 2009-2010.

Ioris, A.A.R. 2010. The political nexus between water and economics in Brazil: a critique of recent policy reforms. Review of Radical Political Economics 42(2): 231-250.

IPCC (Intergovernmental Panel on Climate Change). 2013. Climate change and the sustainable development concept. Available at:

http://www.ipcc.ch/publications_and_data/ar4/wg3/en/ch2s2-1-4.html (last access May 5 2013).

IPEC (Instituto Provincial de Estadísticas y Censos). 2014. Censo 2010 Misiones. Available at: http://www.ipecmisiones.com/w1/ (last access 7 January 2014).

Jarvis, T., Giordano, M. Puri, S., Matsumoto, K., and A. Wolf. 2005. International borders, ground water flow and hydroschizophrenia. Ground Water 43(5): 764-770. 
Jessop, B. 2002. Liberalism, neoliberalism and urban governance. A state-theoretical perspective. Antipode 34(3): 452-472.

Jørgensen, M. and L. Phillips. 2002. Discourse analysis as theory and method. London: SAGE Publications Ltd.

Kebede, S., A. Ketema, and Z. Tesema. 2010. Features of groundwaters in basins shared between Ethiopia and Kenya and the implications for international legislation on transboundary aquifers. Hydrology Journal 18: 1685-1697.

Kemper, K. E., and E. Mestre. 2003. Management of the Guarani Aquifer System. Water International 28(2): 185-200.

Kristin, E. J., and P. J. Ashton. 2008. Adapting to change in transboundary rivers: An analysis of treaty flexibility on the Orange-Senqu river basin. International Journal of Water Resources Development 24(3): 385-400.

Larner, W. 2000. Neo-liberalism: Policy, ideology, governamentality: Studies in Political Economy 63.

Layder, D. 1993. New strategies in social research: An introduction and guide. Cambridge, UK: Polity Press.

Lebel, L., Garden P., and M. Imamura. 2005. The politics of scale, position, and place in the governance of water resources in the Mekong region. Ecology and Society 10(2): 18.

Lewis, M. W. 1992. Green Delusions. Duke University Press. Durham, NC.

Lindsay-Herrera, F. and J. Taks. 2012. Antecedentes y positbilidades para la mayor participacion social en la politica de gestion del Acuifero Guarani. Boletin Geologico y Minero 123(3): 341-352.

Linton, J., and D.B. Brooks. 2011. Governance of transboundary aquifers: new challenges and new opportunities. Water International 36(5): 606-618.

Livesey, S. M. 2002. The discourse of the middle ground: citizen Shell commits to sustainable development. Management Communication Quarterly 15:313-349.

Loftus, A.J. and D.A. McDonald. 2001. Of liquid dreams. A political ecology of water privatization in Buenos Aires. Environment \& Urbanization 13(2): 179-199.

Longhurst, R. 2010. Semi-structured interviews and focus groups In Key Methods in Geography, eds. Clifford, N., French S. and G. Valentine, 103-115. Thousand Oaks, CA: SAGE Publications Inc.

Lukes, S. 2005 [1974]. Power: A Radical View. Hampshire, UK: Palgrave MacMillan. 
Mall, R. K., Gupta, A., Singh, R. and L. S. Rathore. 2006. Water resources and climate change. An Indian perspective. Current Science 90(12): 12-25.

Manahan, S. 2011. Water chemistry: green science and technology of nature's most renewable resource. Boca Raton, FL: CRC Press.

Manghi, E., Bono, J., Montenegro, C., Parmuchi, M. G., Strada, M., Brouver, M., and M. Stamati. 2005. Mapa Forestal de la Provincia de Misiones. República Argentina. Ministerio de Salud y Ambiente. Secretaria de Ambiente y Desarrollo Sustentable.

Mansfield, B. 2004. Neoliberalism in the oceans: "rationalization," property rights, and the commons question. Geoforum 35: 313-326.

Mansfield, B. 2007. Privatization: property and the remaking of nature-society relations. Antipode 39(3): 393-405.

Marston, S. 2000. The social construction of scale. Progress in Human Geography 24(2): 219242.

Marx, K. 1967 [1867]. Capital, Volume 1. New York, NY: International Publishers.

McCaffrey, S. 2011. The International Law Commission's flawed Draft Articles on the law of transboundary aquifers: the way forward. Water International 36(5): 566-572.

McCarthy, J. 2005. Scale, sovereignty, and strategy in environmental governance. Antipode 37(4): 731-753.

McCarthy, J. 2006. Neoliberalism and the politics of alternatives: Community forestry in British Columbia and the United States. Annals of the Association of American Geographers 96(1): 84-104.

McCarthy, J., and S. Prudham. 2004. Neoliberal nature and the nature of neoliberalism. Geoforum 35(3): 275-283.

McDonald, D.A. 2008. World city syndrome: neoliberalism and inequality in Cape Town. New York, NY: Routledge.

McDonald, D. A. and G. Ruiters. 2005. The age of the commodity: Water privatization in South Africa. London, UK: Earthscan.

Mebratu, D. 1998. Sustainability and sustainable development: historical and conceptual review. Environmental Impact Assessment Review 18(6): 493:520.

Media analysis video 1. 2012. Aguas Misioneras fomenta la explotación sustentable. Available at: http://www.youtube.com/watch?feature=endscreen \&v=4X9gHWYYWPM\&NR=1 (last access 13 January 2013). 
Media analysis video 2. 2012. Galeano valoro el carácter social de Aguas Misioneras. Available at: http://www.youtube.com/watch?v=2feNtiV4VAQ (last access 17 January 2013)

Media analysis video 3. 2009. Proyectan crear una sociedad del estado que comercialice el agua. Available at: http://www.youtube.com/watch?v=bKnqLAJjZXg (last access 18 January 2013).

Media analysis video 4. 2012. Agua de las Misiones planteara su derecho a estar presente en Cataratas. Available at: http://www.youtube.com/watch?v=lApo2znleXY (last access 20 January 2013).

Media analysis video 5. 2011. En enero esperamos duplicar nuestra capacidad. Available at: http://www.youtube.com/watch?v=eLvdrt5fdGI (last access 23 January 2013).

Media analysis video 6. 2011. San Javier. Agua de las Misiones. AMSE: 4 mil botellas de agua se producen por turno. Available at: http://www.youtube.com/watch?v=QfgVs_bMfdw (last access 18 January 2013).

Media analysis video 7. 2012. Lic. Gladys Arenhardt - Directora del Centro de Documentación de Aguas Misioneras. Available at: http://www.youtube.com/watch?v=tPzYLqqPmkc (last access 21 January 2013.

Media analysis video 8. 2011.

Jorge Galeano - Pte. De Aguas Misioneras S.A. (AMSE). Available at: http://www.youtube.com/watch?v=IR39PJFOljU (last access 21 January 2013).

Media analysis video 9. 2012. Misiones anticipo la importancia de legislar sobre nuestros recursos. Available at http://www.youtube.com/watch?v=vLpKSrcHrwA (last access 23 January 2013).

Media analysis video 10. 2012. Agua de las Misiones llegara al Congreso para proyectarse a nivel nacional. Available at http://www.youtube.com/watch? $\mathrm{v}=14 \mathrm{erSTNhnr} 8$ (last access 23 January 2013).

Mehta, L. 2003. Context and constructions of water scarcity. Economic and Political Weekly 48: 5066-5072

Ministerio de Ecología. 2014. Ley No. 25.688. Available at:

http://www.ecologia.misiones.gov.ar/ecoweb/index.php/normativa-del-area (last access 8 January 2014).

Misiones Cuatro. 2010. Claro como el agua: Rovira blanqueo su Sociedad con Galeano. Available at:

http://www.misionescuatro.com/ampliar.php?id=14667\&titulo=Claro $\% 20$ como $\% 20 \mathrm{el} \% 2$ 0agua:\%20Rovira\%20blanque\%F3\%20su\%20sociedad\%20con\%20Galeano (last access 16 February 2014).

Misiones Cuatro. 2013. Passalacqua visito la planta de Aguas Misioneras. Available at: http://misionescuatro.com.ar/news.php?name=2013081040 (last access 9 March 2014). 
Molle F. 2008. Nirvana concepts, narratives and policy models: insights from the water sector. Water Alternatives 1(1): 131-156.

National Geographic. 2006. Conspiracists allege U.S. seizing vast U. S. American Rese. Available at http://news.nationalgeographic.com/news/2006/08/060828-guarani_2.html (last access 24 January 2014).

Navarro Lins Brzezinski, M.L. 2010. Regulating transboundary groundwater: big challenges for Brazil. International Conference "Transboundary Aquifers: Challenges and New Directions" (ISRM2010).

Norman, E. S., and K. Bakker. 2009. Transgressing scales: water governance across the CanadaU.S. borderland. Annals of the Association of American Geographers 9(1): 99-117.

Norman, E. S., Bakker, K., and C. Cook. 2012. Introduction to the themed section: water governance and the politics of scale. Water Alternatives 5(1): 52-61.

Noticias del 6. 2013. Recursos para obras hidráulicas con la producción de Aguas Misioneras. Available at: http://www.noticiasdel6.com/ampliar_.php?id=111257 (last access: 9 March 2014).

Noticiero 12. 2013. Con 5 perforaciones alivian la falta de agua en Obera. Available at http://www.noticiero12.com/index.php/interes-general/3538-con-5-perforacionesalivian-la-falta-de-agua-en-obera (last access 11 January 2014).

Nye, J. 2004. Soft Power. New York, NY: Public Affairs.

OAS (Organization of American States). 2005. Guarani Aquifer System. Environmental Protection and Sustainable Development of the Guarani Aquifer System. Office of S ustainable Development and Environment. Water Project Series, Number 7.

Oztan, M., and M. Axelrod. 2011. Sustainable transboundary groundwater management under shifting political scenarios: the Ceylanpinar Aquifer and Turkey-Syria relations. Water International 36(5): 671-685.

Parris, T.M and Kates, R.W. 2003. Characterizing and measuring sustainable development. Annual Review of Environment and Resources 28: 13.1-13.28.

Peck, J. and A. Tickell. 2002. Neoliberalizing space. Antipode 34(3): 380-404.

Peet and Watts. 1996. Liberation Ecologies. New York, NY: Routledge.

Perreault, T. 2005. State restructuring and the scale of politics in rural water governance in Bolivia. Environmental and Planning A 37(2): 263-284.

Perreault, T. 2006. From the Guerra del agua to the guerra del gas: Resource governance, neoliberalism and popular protest in Bolivia. Antipode 38(1): 150-172. 
Perreault, T. 2008. Custom and contradiction: Rural water governance and the politics of usos y costumbres in Bolivia's irrigators' movement. Annals of the Association of American Geographers 98(4): 834-854.

Phillips, D.J.H., Attili, S., McCaffrey, S. and J. S. Murray. 2007. Factors relating to equitable distribution of water in Israel and Palestine. Water Resources 2: 249-255.

Pochat, V. 2011. International agreements, institutions and projects in La Plata River Basin. Water Resources Development 27(3): 497-510.

Potter, J. 2004. Analyzing qualitative data. Discourse analysis. In Handbook of Data Analysis eds. Hardy M. and A. Bryman, 607-624. Thouthand Oaks, CA: SAGE Publications Inc.

Presidencia de la Nación. 2012. Reporte Mas Cerca. Provincia de Misiones.

Prudham, S. 2004. Poisoning the well: Neoliberalism and contamination of municipal water in Walkerton, Ontario. Geoforum 35(3):343-359.

Puri, S., and A. Aureli. 2005. Transboundary aquifers: A global program to assess, evaluate and develop policy. Ground Water 43(5): 661-668.

Rahaman, M. M. 2009. Principles of transboundary water resources management and Ganges treaties: An analysis. Water Resources Development 25(1): 159-173.

Redclift, M. 1987. Sustainable development. Exploring contradictions. New York, NY: Methuen.

Rijsberman, F. R. 2005.Water scarcity: Fact or fiction? Agricultural Water Management 80: $5-22$.

Roberts, A. 2008. Privatizing social reproduction: the primitive accumulation of water in an era of neoliberalism. Antipode 40(4): 535-560.

Robbins, P. 2004. Political ecology. Critical introductions to geography. Oxford, UK: Blackwell Publishing.

Rossi, J. 2014. Personal communication. February 2, 2014.

SAMSA (Servicio de Aguas de Misiones S.A). 2014. Available at http://www.samsa.com.ar/ (last access 21 January 2014).

Sawyer, S. 2004. Crude chronicles. Indigenous politics, multinational oil, and neoliberalism in Ecuador. Duke University Press.

Scheper-Hughes, N. 2005. The last commodity: Post-Human Ethics and the global trade in 'fresh' organs. In Global Assemblages: Technology, Politics and Ethics as Anthropological Problems, eds. Ong, A and S. Collier, 145-168. Oxford: Blackwell.

Shiva, V. 2002. Water wars. Privatization, pollution, and profit. Cambridge, MA: South End Press. 
Síndico, F. 2011. The Guarani Aquifer System and the International Law of Transboundary Aquifers. International Community Law Review 13: 255-272.

Sithole, P. 2011. A comparative study of rural water governance in the Limpopo Basin. Unpublished $\mathrm{PhD}$ diss. University of Western Cape.

Smith, N. 1992. Geography, difference and the politics of scale. In Postmodernism and the social sciences, eds. Doherty, J., Graham, E. and Mallek, M. 57-79. London: MacMillan,

Smith, L. 2004. The murky waters of the second wave of neoliberalism: corporatization as a service delivery model in Cape Town. Geoforum 35(3): 375-393.

Stephan, R. M., ed. 2009. Transboundary aquifers: managing a vital resource. The UNILC draft articles on the law of transboundary aquifers. Paris, France: UNESCO.

Stephan, R.M. 2011. The draft articles on the law of transboundary aquifers: the process at the UN ILC. International Community Law Review 13: 223-235.

Sullivan, K. M. 2001. Discursive practices and competing discourses in the governance of wild North American Pacific salmon resources. In Reflections on water. New approaches to transboundary conflicts and cooperation, eds. Blatter, J. and H. Ingram, 163-189. London, England: The MIT Press.

Swyngedouw, E, 1997. Excluding the other: the production of scale and scaled politics. In Geographies of economies, eds. Lee, R. and J. Willis, 167-178. London: Arnold,

Swyngedouw, E. 2004 Social power and the urbanization of water. Flows of power. Oxford: University Press.

Swyngedouw, E. 2005. Dispossessing $\mathrm{H}_{2} \mathrm{O}$ : The contested terrain of water privatization. Capitalism, Nature, Socialism 16(1): 81-98.

Uitto J.I., and A. Duda. 2002. Management of transboundary water resources: lessons from international cooperation for conflict prevention. The Geographical Journal 168(4): 365378.

U.N. (United Nations). 2013a. Report of the United Nations Conference on Environment and Development. Available at: http://www.un.org/documents/ga/conf151/aconf151261annex1.htm (last access 31 May 2013).

U.N. (United Nations). 2013b. Integrated Water Resources Management (IWRM). Available at: http://www.un.org/waterforlifedecade/iwrm.shtml (last access 23 January 2014).

U.N. (United Nations). 2013c. Water scarcity. Available at: http://www.un.org/waterforlifedecade/scarcity.shtml (last access 9 June 2013).

U.N. (United Nations). 2013d. Resolution adopted by the General Assembly on 11 December 2008. The law of transboundary aquifers. Available at: 
http://www.un.org/en/ga/search/view_doc.asp?symbol=A/RES/63/124\&Lang=E (last access 2 November 2013).

UNESCO (United Nations Educational Scientific and Cultural Organization). 2014. Valuing water. Available at http://webworld.unesco.org/water/wwap/facts_figures/valuing_water.shtml (last access 1 June 2013).

UNICEF and WHO (UNICEF and World Health Organization). 2012. Progress on drinking water and sanitation. Joint Monitoring Programme for Water Supply and Sanitation.

Vaux, H. 2011. Groundwater under stress: the importance of management. Environmental Earth Science 62: 19-23.

Villar, P. C. and W. C. Ribeiro. 2011. The agreement on the Guarani Aquifer: a new paradigm for transboundary groundwater management. Water International 36(5): 646-660.

Whiteford, L., and S. Whiteford, eds. 2005. Globalization, Water, \& Health. Resource Management in times of scarcity. Santa Fe, NM: School of American Research Press.

Wolf, A.T. 2007. Shared waters: conflict and cooperation. Annual Review of Environment and Resources 32: 241-269.

Wolf, A. T., Yoffe, S. B. and M. Giordano. 2003. International waters: identifying basins at risk. Water Policy 5: 29-60.

World Bank. 2006. The Guarani Aquifer initiative for transboundary groundwater management. Sustainable groundwater management. Lessons from practice. Case Profile Collection Nr. 9.

World Bank. 2009. Implementation completion and results report. Environmental Protection and Sustainable Development of the Guarani Aquifer System Project.

World Bank. 2013. Sustainable Development. Available at http://www.worldbank.org/depweb/english/sd.html (last access 5 June 2013).

World Bank 2014. Argentina Overview. Available at: http://www.worldbank.org/en/country/argentina/overview (last access 18 January 2014).

Yeung, H. W. 1997. Critical realism and realist research in human geography: a method or a philosophy in search of a method? Progress in Human Geography 21(1): 51-74.

Young O.R. 1996. Rights, rules and resources in international society. In Rights to nature: Ecological, Economic, Cultural, and Political Principles, ed. Arrow, K. 345-263. Washington, DC: Island Press. 
Zeitoun, M. 2008. Power in the Middle East. The hidden politics of the Palestinean-Israel water conflict. New York, NY: I.B. Tauris \& Co. Ltd.

Zeitoun, M., and J.A. Allan. 2008. Applying hegemony and power theory to transboundary water analysis. Water Policy 2: 3-12.

Zeitoun, M., and N. Mirumachi. 2008.Transboundary water interaction I: reconsidering conflict and cooperation. International Environmental Agreements 8: 297-316.

Zeitoun, M., and J. Warner. 2006. Hydro-hegemony - a framework of analysis for transboundary water conflicts. Water Policy 8: 435-460.

Zeitoun, M., Messerschmid, C. and S. Attili. 2009. Asymmetric abstraction and allocation. The Israeli-Palestinian Water Pumping Record. Ground Water 47(1): 146-160. 


\section{Appendix A}

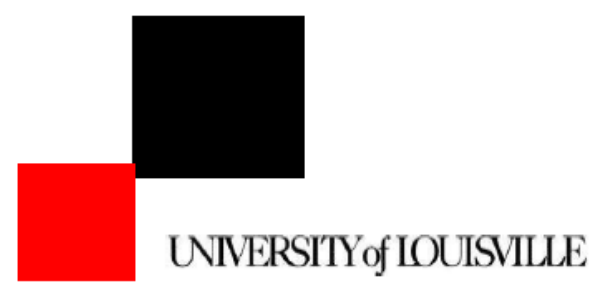

INSTITUTIONAL REVIEW BOARDS

University of Louisville

MedCenter One, Suite 200

$501 \mathrm{E}$. Broadway

Louisville, Kentucky 40202-1798

Office: $\quad 502-852-5188$

Fax: $\quad$ 502-852-2164

To: $\quad$ Walker, Margath

From: The University of Louisville Institutional Review Board (IRB)

Date: Thursday, January 24, 2013

Subject: Approval Letter

Tracking \#: 12.0521

Title: Water Governance and Conflicts in the Guarani Aquifer

Approval 1/22/2013 12:00:00 AM

Date:

Expiration $1 / 21 / 2014$ 12:00:00 AM

Date: 
Appendix B

Questionnaire

(Spanish Version)

1. Como está usted relacionado/a con la gobernación de agua en la provincia de Misiones?

2. En su opinión, que tipo de gobernación de agua existía en la provincia de Misiones hace 10 años?

Algunas opciones:

a) Manejo de servicios de agua regulados por la comunidad

b) Manejo de servicios de agua regulados por el estado

c) Manejo de servicios de agua regulados por el sector privado

d) Hibrido (Describir)

e) Otros (Describir)

3. Que presencia tenía el estado provincial en estos procesos o regímenes en aquel entonces?
a) Involucramiento completo
b) Involucramiento parcial
c) No tenía involucramiento
d) Otro (Describir)

4. Cuál era, hace aproximadamente 10 años, la participación de la comunidad en estos procesos?
a) Involucramiento completo
a) Involucramiento parcial
b) No tenía involucramiento
c) Otro (Describir)

5. En su opinión, que tipo de gobernación de agua existe en la provincia de Misiones en la actualidad?
a) Manejo de servicios de agua regulados por la comunidad
b) Manejo de servicios de agua regulados por el estado
c) Manejo de servicios de agua regulados por el sector privado
d) Hibrido (Describir)
e) Otros (Describir)

6. Cuál es la presencia del estado provincial en estos procesos o regímenes en la actualidad?
a) Involucramiento completo
b) Involucramiento parcial
c) No hay involucramiento del estado
d) Otros (Describir)

7. Cuál es, en la actualidad, la participación de la comunidad en estos procesos?
a) Involucramiento completo
b) Involucramiento parcial (régimen hibrido)
c) No había involucramiento
d) Otro (Describir) 


\section{SI HUBIERON CAMBIOS EN LA PARTICIPACION DE LA COMUNIDAD Y/O DEL ESTADO CONTINUAR CON \# 8}

8. Que factores han influenciado estos cambios?

9. En su opinión y conocimiento, en que porcentajes se distribuye el agua captada en la provincia de Misiones para cada tipo de agua y uso y/o destino?
a) Industrial
b) Agrícola
c) Doméstico (Servicio de agua corriente a la comunidad)
d) Exportación
e) Comercio interno (a otras provincias)
f) Otros (Describir)

10. Que recursos de agua utiliza la provincia de Misiones y en que porcentajes aproximadamente y volúmenes mensuales y/o anuales?
a) Subterráneas
b) Aguas superficiales
c) Aguas pluviales
d) Otras (Describir)

11. Cuáles son las principales participantes (empresas y/u organismos provinciales, nacionales y/o internacionales) que intervienen en el proceso de captación de agua proveniente del territorio de la provincia de Misiones (para varios usos: domestico, industrial, agrícola, comercialización de agua embotellada, etc.)?

12. Cuáles son los principales organizaciones/agencias nacionales, transnacionales y/o supranacionales que participan en la gobernación de agua del Acuífero Guaraní?

13. De qué manera participan?

14. Como usted considera que el agua se percibía en la provincia de Misiones hace 10 años?
a) Un derecho humano
b) Un bien económico
c) Un bien de dominio publico
d) Un bien de dominio provincial
e) Simplemente "agua de las Misiones"
f) Otros (describir)

15. Como usted considera que el agua se percibe en la provincia en la actualidad?
a) Un derecho humano
b) Un bien económico
c) Un bien de dominio publico
d) Un bien de dominio provincial
e) Simplemente "agua de las Misiones"
f) Otros (describir) 


\section{SI HUBIERON CAMBIOS:}

16. En su opinión, que factores influenciaron estos cambios en la forma de percibir el agua en la provincia?

17. Cuál es el volumen aproximado de extracción de agua subterránea (del Acuífero Guaraní) mensual/anual que surge desde la provincia de Misiones?

18. Como se controlan/regulan las extracciones de agua del Acuífero Guaraní en la provincia de Misiones? Cuáles son esas regulaciones y cuáles son las entidades provinciales responsables?

19. Cuáles son los mayores captadores de agua subterránea en la provincia de Misiones? Aproximadamente, cuáles son sus volúmenes de captación mensuales o anuales?

20. Cuál es el rol que juega el tratado internacional de las Naciones Unidas para el manejo de Aguas Transfronterizas con respecto a las extracciones de agua en la provincia?

21. Que otros instrumentos provinciales, nacionales, y/o internacionales prevalecen por sobre el tratado internacional de Aguas Transfronterizas de las Naciones Unidas? Cuáles son? En que se basan?

22. Como establece la provincia de Misiones la "equitativa y razonable utilización" de aguas subterráneas (regulación incorporada en los artículos del tratado de Aguas Transfronterizas de las Naciones Unidas) con otros estados soberanos del acuífero?

23. Como establece la provincia de Misiones, en conjunto con otros estados soberanos del acuífero Guaraní, que las actividades de captación de agua subterránea pasadas y presentes no representan un "daño significativo" para el uso sustentable del acuífero?

24. Tiene la provincia de Misiones autonomía de poder sobre el nivel nacional y el internacional con respecto a la gobernación del Acuífero Guaraní? Si "si": Podría describir esto? Que instrumentos informales y/o formales existen y/o interceden?

25. Cuáles son las iniciativas de la provincia de Misiones para promover la gobernación/gestión sustentable del Acuífero Guaraní?

26. Cuál es su comentario acerca del desarrollo sustentable del Acuífero Guaraní?

27. Cuál es la inherencia de la provincia de Misiones en las relaciones internacionales con respecto a la gobernación del acuífero?

28. Sabe usted cual es el volumen de recarga natural anual del Acuífero Guaraní?

29. Que mecanismos de control se han establecido por la provincia de Misiones para asegurar la sustentabilidad del acuifero?

30. Existe en la actualidad, algún tipo de conflicto sobre el agua, en la provincia de Misiones, relacionado con actividades como por ejemplo, de minería, excesiva extracción de agua, sequias, falta de acceso a agua potable, contaminación, u otros? Describir. 


\section{Appendix C \\ Questionnaire \\ (English Version)}

1. What is your relationship with the water governance in the province of Misiones? Do you have any other memberships?

2. In your opinion, what kind of water governance was present in Misiones 10 years ago?

a) Water services managed by the community

b) Water services managed by the State

c) Water services managed by the private sector

d) Hybrid (Describe)

e) Others (Describe)

3. What was the provincial State's presence in these processes back then?
a) Full involvement
b) Partial involvement
c) No involvement
d) Others (Describe)

4. What was the public participation in these processes or regimes back then?
a) Full involvement
b) Partial involvement
c) No involvement
d) Others (Describe)

5. In your opinion, what kind of water governance is currently present in the province?
a) Water services managed by the community
b) Water services managed by the State
c) Water services managed by the private sector
d) Hybrid (Describe)
e) Others (Describe)

6. What is the current provincial State's presence in these processes?
e) Full involvement
f) Partial involvement
g) No involvement
h) Others (Describe)

7. What is the current public participation in these processes or regimes?

e) Full involvement

f) Partial involvement 
g) No involvement

h) Others (Describe)

IF THERE WERE CHANGES IN THE PUBLIC PARTICIPATION AND/OR THE STATE INVOLVEMENT CONTINUE WITH QUESTION \# 8

8. In your opinion, what factors influenced these changes?

9. To your knowledge, how is water allocated in the province? Could you provide me with an approximate percentage for each sector?
a) Industrial
b) Agricultural
c) Domestic
d) Internal business for transfers (or to other provinces)
e) Others

10. What type of water resources does Misiones utilize for the province and in what percentages and volumes (monthly/ annually)?
a) Groundwater
b) Superficial
c) pluvial
d) Others (Describe)

11. What are the main participants (corporations and/or provincial, national and/or international organizations intervening in the water extraction process in the province of Misiones, for various uses such as domestic, industrial, agricultural, bottling water, etc.

12. What are the main organizations and/or agencies (national, transnational and/or supranational) that intervene in the governance of the Guaraní Aquifer?

13. How do they participate?

14. In your opinion, how was water perceived in the province 10 years ago?
a) A human right
b) An economic good
c) A public domain good
d) A provincial good
e) Others

15. In your opinion, how do you think water is currently perceived in the province?
a) A human right
b) An economic good
c) A public domain good
d) A provincial good
e) Others 


\section{IF THERE WERE CHANGES IN PERCEPTION}

16. In your opinion, what factors influenced these changes? (in the way to perceive water in the province).

17. What is the approximate volume of groundwater extraction from the Guarani Aquifer monthly/ annually in the province of Misiones?

18. How is groundwater extractions from the Guarani Aquifer controlled and regulated in the province? What are the current regulations and the organizations responsible?

19. Who are the main groundwater extractors in the province of Misiones? What are their volumes of extraction (monthly/ annually)?

20. What is the role of the United Nations international treaty in the transboundary groundwater governance in relation to the water extractions of the province?

21. What other provincial, national and/or international legal instruments prevail over the United Nations Transboundary Aquifers treaty? Which are they? What are they based on?

22. How does the province establish the "equitable and reasonable utilization" of transboundary groundwater (a United Nations on the Law of Transboundary Aquifers principle) with other sovereign States to the aquifer?

23. How does the province establish, among other sovereign States of the Guarani Aquifer, that past and present groundwater exploitation activities do not represent a "significant harm" to the sustainable governance of the aquifer?

24. Does the province of Misiones have autonomy over the national and international level in relation to the governance of the Guaraní Aquifer? Could you describe? What formal and/or informal instruments intervene?

25. What are the provincial initiatives to promote the sustainable governance of the Guarani Aquifer?

26. What is your commentary on the sustainable governance of the Guarani Aquifer?

27. What is Misiones' inherence in the international relations in relation to the governance of the Guarani Aquifer?

28. What is the recharge volume of the Guarani Aquifer?

29. What are the main control and enforcement activities carried out in the province to ensure the sustainability of the aquifer?

30. Are there any current water conflicts in the province such as for example, in relation to activities of mining, overexploitation, water scarcity, lack of potable water access, contamination or others? Describe. 
Appendix D

Media News Videos

Video 1

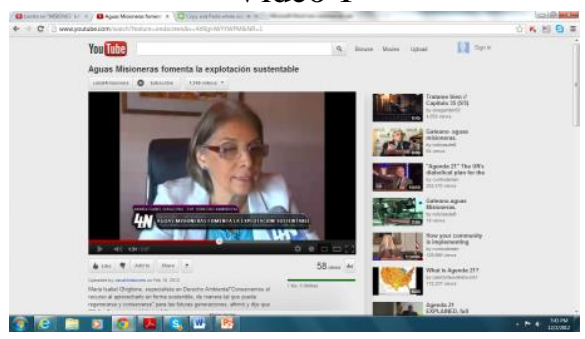

Video 2

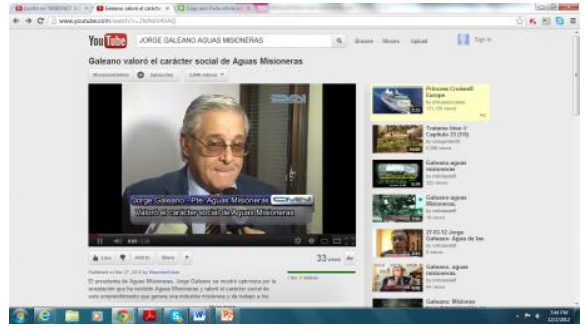

Video 3

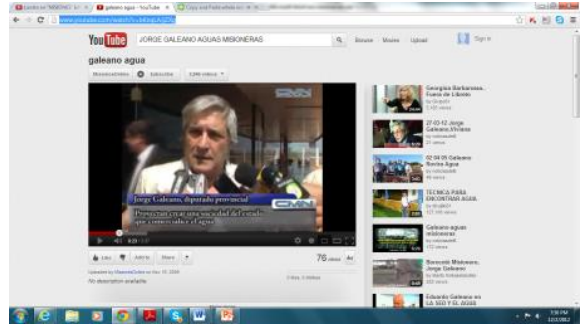

Video 4

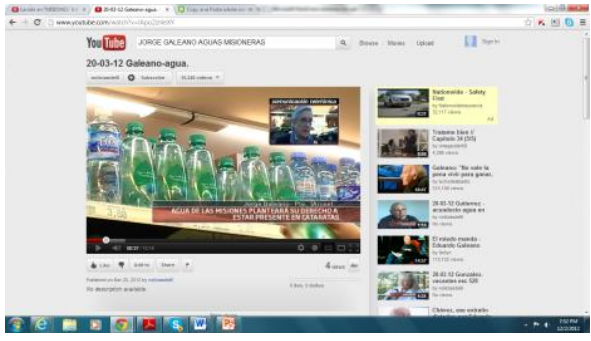

Video 5

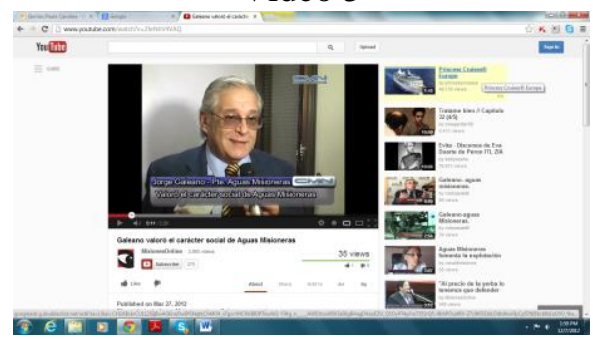

Video 6
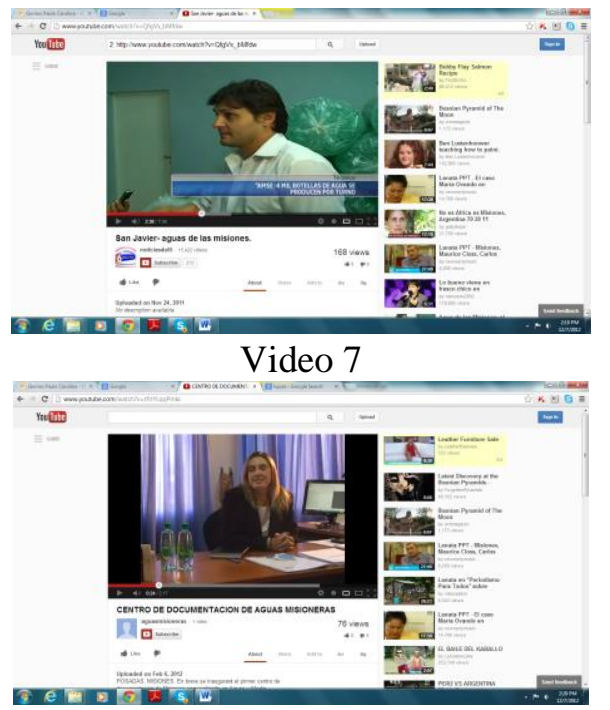

Video 8

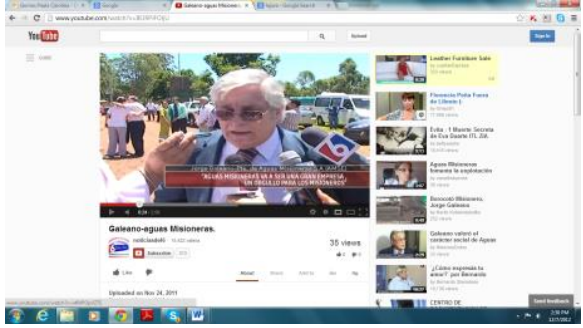

Video 9

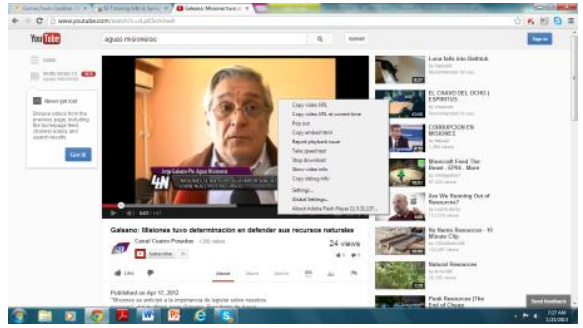

Video 10

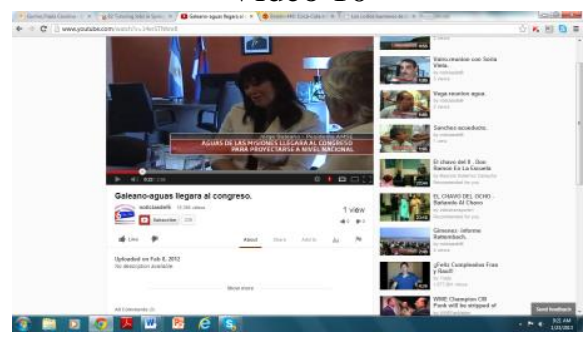




\section{CURRICULUM VITAE}

NAME:

ADDRESS:

DOB:

EDUCATION \& TRAINING:

PROFESSIONAL EXPERIENCE:

PROFESSIONAL SOCIETIES:

CONFERENCES \& PAPER PRESENTATIONS:
Paula Carolina Gómez

18 Tender Violet Place

The Woodlands, TX 77381

June 14, 1974

M.S., Applied Geography University of Louisville 2010-2014

B.A., Psychology

University of Louisville

2007-2010

Water Conservation Program Coordinator at The Woodlands Township. The Woodlands, Texas.

Member of the Association of American Geographers since 2012

University of Kentucky

Lexington, Kentucky. February 28 - March 2, 2013

Dimensions of Political Ecology (DOPE)

Conference on Nature/ Society

Paper presented: Transboundary Groundwater and

Unsustainable Practices of Water Governance in the Guarani

Aquifer: The Case of the Province of Misiones. 